\title{
1994 Annual Report on Alaska’s Mineral Resources
}

\author{
U.S. GEOLOGICAL SURVEY CIRCULAR 1113
}

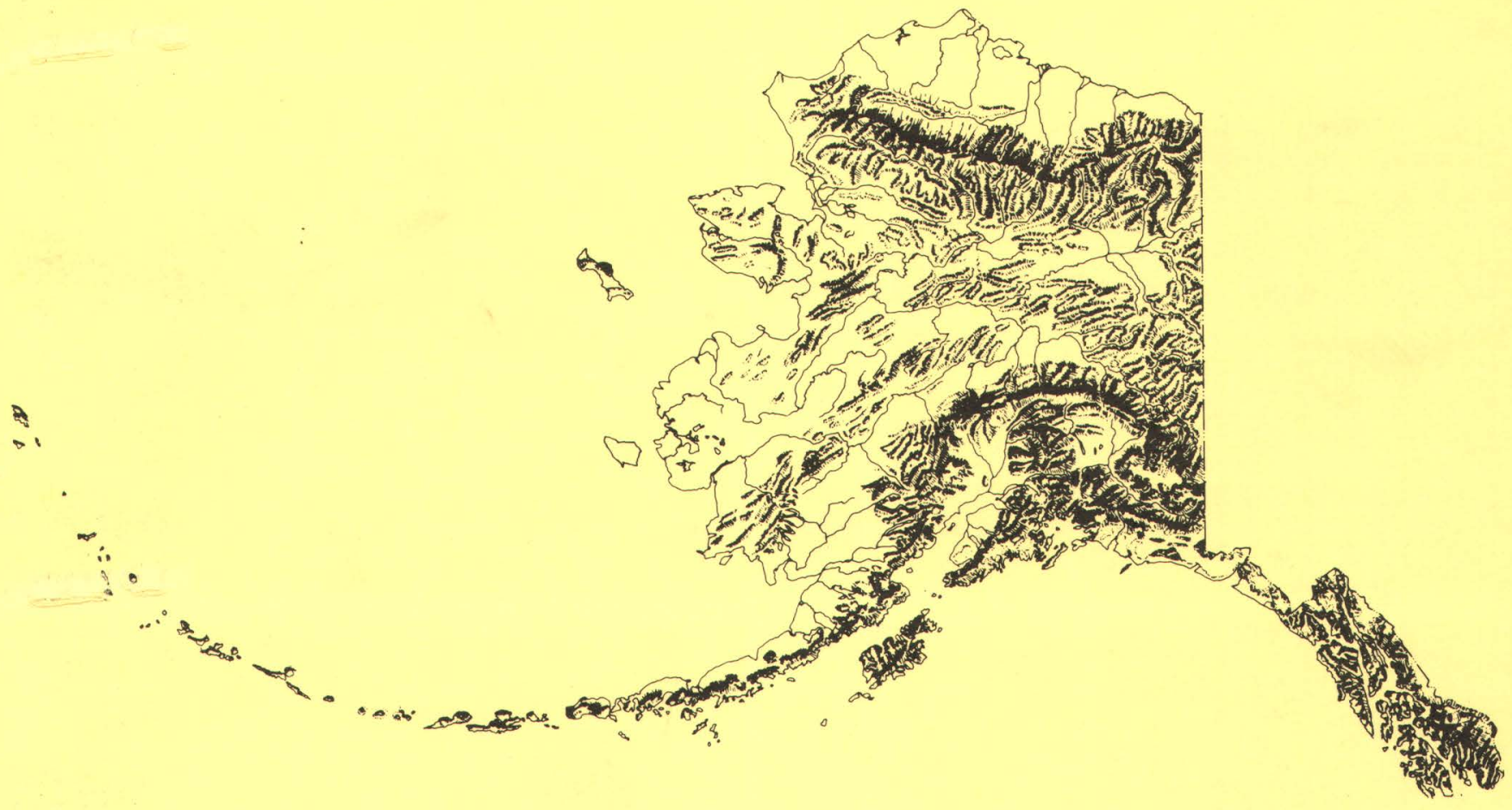

Prepared in cooperation with the Bureau of Land Management, the Minerals Management Service, the National Park Service, the U.S. Bureau of Mines, the U.S. Fish and Wildlife Service, the U.S. Forest Service, and the Department of Energy, as mandated by Section 1011 of the Alaska National Interest Lands Conservation Act, Public Law 96-487, of December 2, 1980

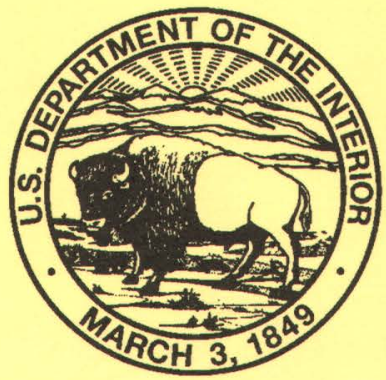


Instructions on ordering publications of the U.S. Geological Survey, along with prices of the last offerings, are given in the currentyear issues of the monthly catalog "New Publications of the U.S. Geological Survey." Prices of available U.S. Geological Survey publications released prior to the current year are listed in the most recent annual "Price and Availability List." Publications that are listed in various U.S. Geological Survey catalogs (see back inside cover) but not listed in the most recent annual "Price and Availability List" are no longer available.

Reports released through the NTIS may be obtained by writing to the National Technical Information Service, U.S. Department of Commerce, Springfield, VA 22161; please include NTIS report number with inquiry.

Order U.S. Geological Survey publications by mail or over the counter from the offices given below.

\section{BY MAIL}

\section{Books}

Professional Papers, Bulletins, Water-Supply Papers, Techniques of Water-Resources Investigations, Circulars, publications of general interest (such as leaflets, pamphlets, booklets), single copies of Earthquakes \& Volcanoes, Preliminary Determination of Epicenters, and some miscellaneous reports, including some of the foregoing series that have gone out of print at the Superintendent of Documents, are obtainable by mail from

\section{U.S. Geological Survey, Information Services Box 25286, Federal Center Denver, CO 80225}

Subscriptions to periodicals (Earthquakes \& Volcanoes and Preliminary Determination of Epicenters) can be obtained ONLY from the

\section{Superintendent of Documents Government Printing Office \\ Washington, DC 20402}

(Check or money order must be payable to Superintendent of Documents.)

\section{Maps}

For maps, address mail orders to

\section{U.S. Geological Survey, Map Distribution Box 25286, Bldg. 810, Federal Center Denver, CO 80225}

Residents of Alaska may order maps from

\author{
U.S. Geological Survey, Earth Science Information Center \\ 101 Twelfth Ave., Box 12 \\ Fairbanks, AK 99701
}

\section{OVER THE COUNTER}

\section{Books and Maps}

Books and maps of the U.S. Geological Survey are available over the counter at the following U.S. Geological Survey offices, all of which are authorized agents of the Superintendent of Documents.

- ANCHORAGE, Alaska-4230 University Dr., Rm. 101

- LAKEWOOD, Colorado-Federal Center, Bldg. 810

- MENLO PARK, California-Bldg. 3, Rm. 3128, 345 Middlefield Rd.

- RESTON, Virginia-National Center, Rm. 1C402, 12201 Sunrise Valley Dr.

- SALT LAKE CITY, Utah-Federal Bldg., Rm. 8105, 125 South State St.

- SPOKANE, Washington-U.S. Post Office Bldg., Rm. 135, W. 904 Riverside Ave.

- WASHINGTON, D.C.-Main Interior Bldg., Rm. 2650, 18th and C Sts., NW.

\section{Maps Only}

Maps may be purchased over the counter at the U.S. Geological Survey offices:

- FAIRBANKS, Alaska-New Federal Building, 101 Twelfth Ave.

- ROLLA, Missouri-1400 Independence Rd.

- STENNIS SPACE CENTER, Mississippi-Bldg. 3101 
1994 Annual Report on Alaska's Mineral Resources 


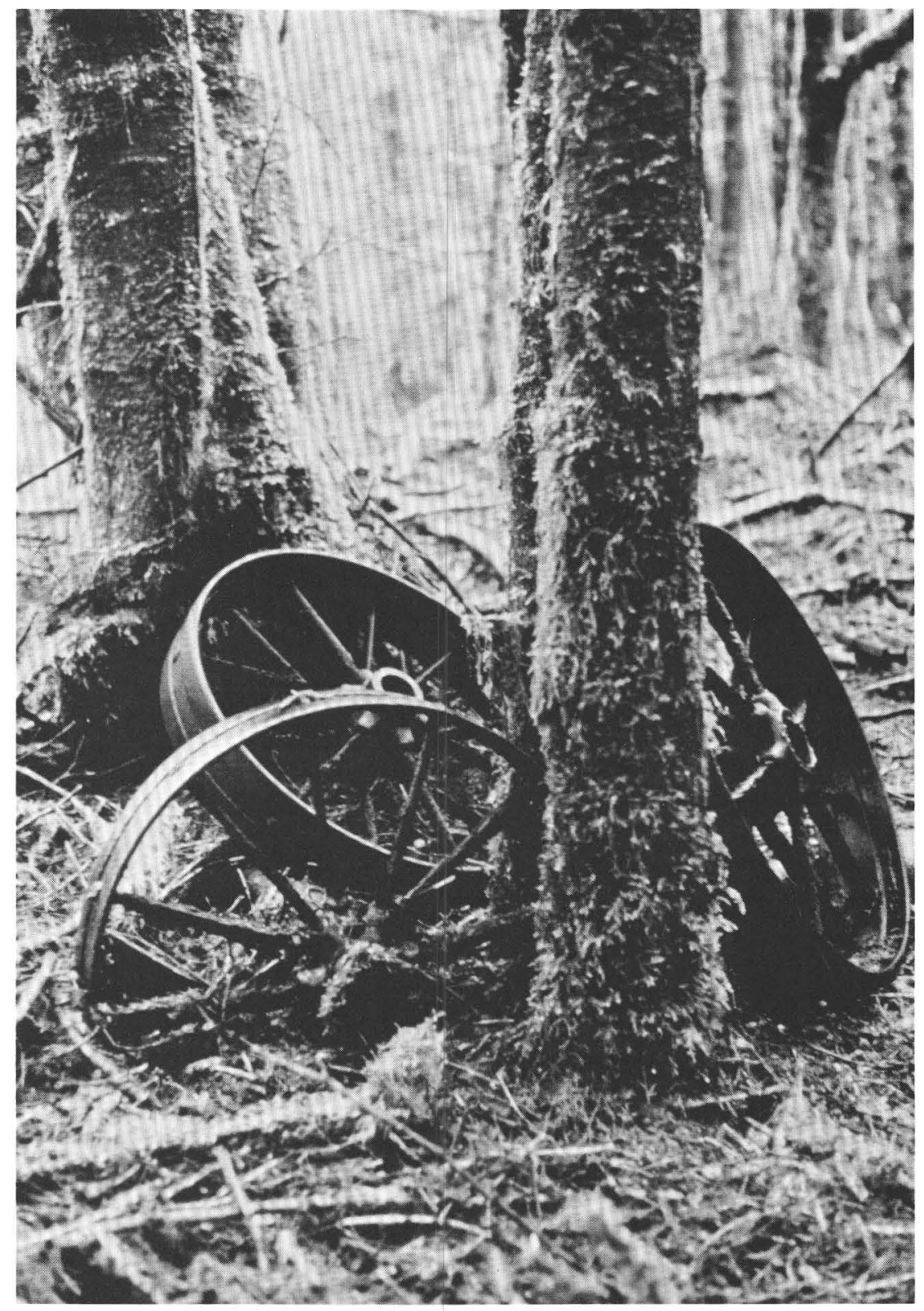

Frontispiece. Three belt wheels lay idle outside main adit of inactive Gold Standard Mine, located in Tongass National Forest near Helm Bay in southeastern Alaska. An inventory of abandoned mine hazards in Tongass National Forest is scheduled for 1995. The USBM and USFS have already conducted a similar survey in Chugach National Forest to determine chemical and physical hazards that may have resulted from past mining activities. Photograph by K. Maas. 


\title{
1994 Annual Report on Alaska's Mineral Resources
}

\author{
JILL L. SCHNEIDER, Editor
}

U.S. GEOLOGICAL SURVEY CIRCULAR 1113

Prepared in cooperation with the Bureau of Land Management, the Minerals Management Service, the National Park Service, the U.S. Bureau of Mines, the U.S. Fish and Wildlife Service, the U.S. Forest Service, and the Department of Energy, as mandated by Section 1011 of the Alaska National Interest Lands Conservation Act, Public Law 96-487, of December 2, 1980

A summary of mineral resource activities in Alaska during 1993 


\title{
U.S. DEPARTMENT OF THE INTERIOR BRUCE BABBITT, Secretary
}

\author{
U.S. GEOLOGICAL SURVEY \\ Gordon P. Eaton, Director
}

Free on application to the U.S. Geological Survey, Information Services

Box 25286, Federal Center

Denver, CO 80225

\begin{abstract}
Any use of trade, product, or firm names in this publication is for descriptive purposes only and does not imply endorsement by the U.S. Government.
\end{abstract}




\section{CONTENTS}

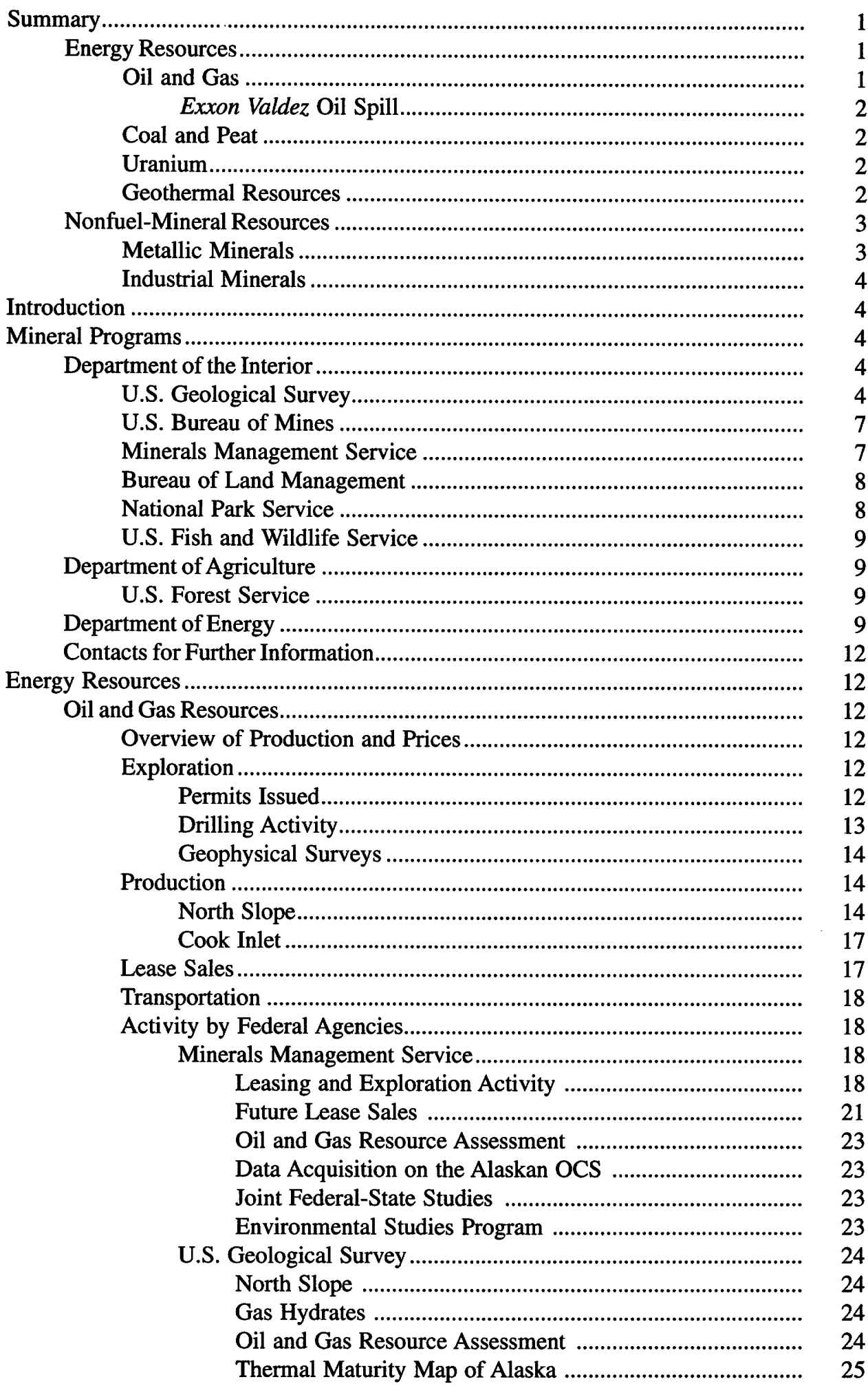


Energy Resources-Continued

Oil and Gas Resources-Continued

Activity by Federal Agencies-Continued

Bureau of Land Management ........................................................... 25

Resource Evaluation .......................................................... 25

Lease Operations ................................................................... 25

Pipeline Monitoring …......................................................... 26

National Park Service ....................................................................... 26

U.S. Fish and Wildlife Service ...................................................... 26

Kenai National Wildlife Refuge ....................................... $\quad 26$

Arctic National Wildlife Refuge .......................................... 28

Activities under Section 1008 of ANILCA ........................ 28

Resource Activity Impact Assessment ............................... 28

Department of Energy ............................................................ 29

Exxon Valdez, Oil Spill.............................................................................. 29

Activity by Federal Agencies.......................................................... 29

Minerals Management Service ........................................... 29

National Park Service ............................................................ $\quad 30$

U.S. Fish and Wildlife Service ........................................ $\quad 30$

Coal and Peat Resources .......................................................................... 31

Overview of Industry Activity.............................................................. $\quad 31$

Activity by Federal Agencies .............................................................. $\quad 33$

U.S. Geological Survey........................................................... 33

U.S. Bureau of Mines ................................................................. 33

National Park Service ................................................................. $\quad 33$

Department of Energy ................................................................ 33

Uranium Resources............................................................................... 34

Overview of Industry..................................................................... 34

Activity by Federal Agencies ............................................................... $\quad 34$

U.S. Geological Survey.............................................................. 34

U.S. Fish and Wildlife Service .................................................... 34

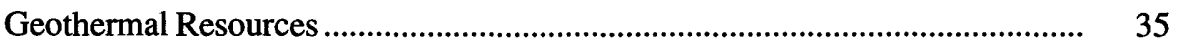

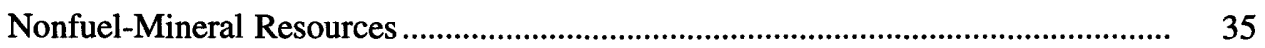

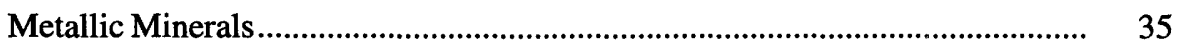

Economic Overview .......................................................................... 35

Precious Metals............................................................................... 35

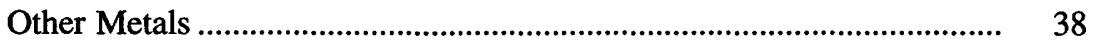

Activity by Federal Agencies ............................................................ $\quad 38$

U.S. Geological Survey............................................................ 38

Alaska Mineral Resource Assessment Program ................ 39

Precious Metals ................................................................. 41

Strategic and Critical Minerals ........................................... 43

Environmental Studies ..................................................... 43

Cooperative Programs with Foreign Scientific Agencies .... 43

Trans-Alaska Crustal Transect (TACT) .............................. 44

Colville Mining District ....................................................... 44

Chugach National Forest Special Study Area .................... 44

U.S. Bureau of Mines ................................................................ 44

Minerals Availability Program .......................................... 45

Policy Analysis ................................................................. 45

State Mineral Activities .......................................................... 45

Mineral Land Assessment .................................................... 46

Minerals Research ............................................................. 48

Bureau of Land Management ..................................................... $\quad 50$ 
Nonfuel-Mineral Resources-Continued

Metallic Minerals-Continued

Activity by Federal Agencies-Continued

National Park Service .............................................................. $\quad 50$

Mining Claim Activities .................................................... $\quad 50$

Abandoned Mineral Lands Reclamation ............................ 51

Reclamation Research ...................................................... 51

Other Activities ................................................................ 52

U.S. Fish and Wildlife Service ..................................................... 52

U.S. Forest Service ...................................................................... 52

Minerals Development in Tongass National Forest ........... 53

Mineral Patents ................................................................ 53

Exploration on National Forest Lands ................................ 53

Industrial Minerals ........................................................................................... 53

Overview of Industry Activity............................................................... 53

Activity by Federal Agencies ............................................................... 54

U.S. Geological Survey............................................................... 54

U.S. Bureau of Mines ................................................................ 54

Bureau of Land Management ..................................................... $\quad 55$

U.S. Fish and Wildlife Service .................................................. 55

U.S. Forest Service …............................................................. 55

References Cited ...................................................................................................... 55

Appendix 1. Alaska Mineral Reports Released During 1993 and Early 1994.......... 56

Department of the Interior....................................................................................... 56

U.S. Geological Survey ...................................................................... 56

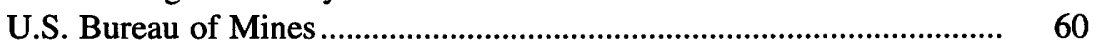

Minerals Management Service ................................................................. $\quad 60$

Bureau of Land Management .............................................................. 62

National Park Service .......................................................................... 62

U.S. Fish and Wildlife Service........................................................... 62

Department of Energy ................................................................................. $\quad 62$

Non-Federal Reports................................................................................. 63

Alaska Division of Geological and Geophysical Surveys....................... 63

Additional Non-Federal Publications ......................................................... 64

Appendix 2. Roles of Federal Agencies in Mineral Programs ................................... 66

Department of the Interior........................................................................... 66

U.S. Geological Survey .......................................................................... 66

U.S. Bureau of Mines ............................................................................ 66

Minerals Management Service .............................................................. $\quad 67$

Bureau of Land Management .................................................................. 67

National Park Service .......................................................................... 68

U.S. Fish and Wildlife Service............................................................ 68

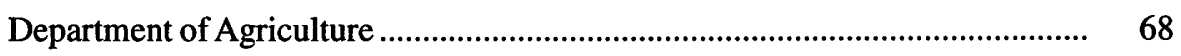

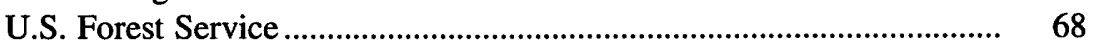

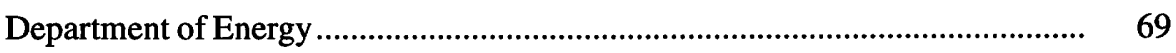

\section{FIGURES}

Frontispiece. Photograph of belt wheels at Gold Standard Mine, Tongass National Forest .......................................... II

1. Map of Federal land ownership in Alaska.......................................................................................... 5

2. Photograph of fossil leaf from hot spring deposit, Russian Mission quadrangle ........................................... 6

3. Map of National wildlife refuges in Alaska ............................................................................................ 10 
4. Photograph of USFS mineral examiner inspecting location notice of claim block in Tongass National Forest

5. Graph showing fluctuation in annual average price of Alaska North Slope crude oil, 1987-1993 ........... 14

6-12. Maps showing:

6. Locations of exploratory oil wells drilled in 1993, oil and gas fields, and possible petroleum-bearing sedimentary basins

7. Alaska Outer Continental Shelf Region planning areas and lease sale history...............................

8. Areas proposed by the MMS for future lease sales or geologic and environmental studies: 1992-1997.

9. Onshore favorable petroleum provinces, land units referred to in text, and locations of DOE-funded research in 1993

10. Areas of potential coal, uranium, and geothermal resources mentioned in text

11. Areas of significant industry activity involving metallic minerals (excluding uranium) in 1993, and mine and deposit locations referred to in text

12. Status of USGS level III AMRAP quadrangle studies as of January 1994

13. Photograph of USGS geologists mapping in rugged terrain of Kiokluk Mountains, Sleetmute quadrangle

14. Map showing locations of USGS level II and level IV AMRAP metallic-mineral and TACT studies in 1993

15. Photograph of abandoned dredge, Fortymile Mining District

16. Map showing locations of 1993 USBM study areas listed in table 10

17-19. Photographs showing:

17. USBM geologist examining banded-sulfide mineralization in Hyder area of Ketchikan

Mining District.

18. Quartz-fluorite vein, Chugach National Forest special study area

19. USFS mineral examiner and geologist sampling collar of shaft at Tracy claim block in Tongass National Forest

\section{TABLES}

1. USFS Ranger Districts in Alaska

2. 1993 Alaskan oil and gas production statistics...

3. Fluctuation in price of Alaska North Slope crude oil, 1993

4. Alaska exploratory oil wells drilled in 1993

5. Alaska Outer Continental Shelf leases and wells drilled, 1976-1992

6. Bonus bids received from lease sales on Alaska Outer Continental Shelf planning areas ................................... 18

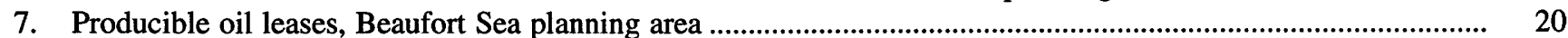

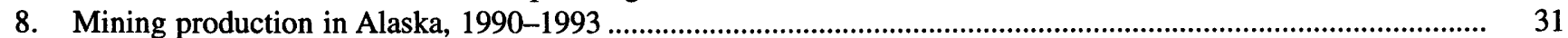

9. Level IV studies of the USGS Alaska Mineral Resource Assessment Program and related projects active in 1993

10. USBM study areas in 1993 . 


\section{ACRONYMS AND ABBREVIATIONS}

\begin{tabular}{|c|c|}
\hline $\mathrm{ACE}$ & U.S. Army Corps of Engineers \\
\hline ADEC & Alaska Department of Environmental Conservation \\
\hline ADFG & Alaska Department of Fish and Game \\
\hline ADGGS & Alaska Division of Geological and Geophysical Surveys \\
\hline AESP & Alaska Environmental Studies Program \\
\hline AFOC & Alaska Field Operations Center \\
\hline AIDEA & Alaska Industrial Development and Export Authority \\
\hline A-J & Alaska-Juneau \\
\hline AMRAP & Alaska Mineral Resource Assessment Program \\
\hline ANILCA & Alaska National Interest Lands Conservation Act \\
\hline ARCO-AK & ARCO Alaska \\
\hline ARDF & Alaskan Resource Data File \\
\hline $\mathrm{bbl} / \mathrm{d}$ & barrels per day (of oil) \\
\hline BLM & Bureau of Land Management \\
\hline BPX & BP Exploration (Alaska) \\
\hline Btu & British thermal unit \\
\hline CIS & Commonwealth of Independent States \\
\hline CFR & Code of Federal Regulations \\
\hline DOE & Department of Energy \\
\hline DOI & Department of the Interior \\
\hline DST & deep stratigraphic test \\
\hline EIS & Environmental Impact Statement \\
\hline EPA & Environmental Protection Agency \\
\hline FWS & U.S. Fish and Wildlife Service \\
\hline$g / t$ & grams per metric ton \\
\hline GIS & Geographic Information System \\
\hline GVEA & Golden Valley Electric Association \\
\hline I\&E & Inspection and Enforcement \\
\hline JPO & Joint Pipeline Office \\
\hline MAS & Minerals Availability System \\
\hline MILS & Minerals Industry Location System \\
\hline MMS & Minerals Management Service \\
\hline MRDS & Mineral Resources Data System \\
\hline NIS & Newly Independent States of the former Soviet Union \\
\hline NOAA & National Oceanic and Atmospheric Administration \\
\hline NP\&P & National Park and Preserve \\
\hline NPRA & National Petroleum Reserve-Alaska \\
\hline NPS & National Park Service \\
\hline NWR & National Wildlife Refuge \\
\hline OCS & Outer Continental Shelf \\
\hline PGM & platinum-group metal \\
\hline ppm & parts per million \\
\hline REE & rare-earth elements \\
\hline SAMRAP & State of Alaska Mineral Resource Assessment Program \\
\hline SESU & Social and Economic Studies Unit \\
\hline SRCMP & Studies Related to Continental Margins Program \\
\hline TACT & Trans-Alaska Crustal Transect \\
\hline TAPS & Trans-Alaska Pipeline System \\
\hline USBM & U.S. Bureau of Mines \\
\hline USCG & U.S. Coast Guard \\
\hline USFS & U.S. Forest Service \\
\hline USGS & U.S. Geological Survey \\
\hline
\end{tabular}




\section{INTERNATIONAL SYSTEM OF UNITS (SI) CONVERSION TABLE ${ }^{1}$}

\begin{tabular}{rcl}
\hline To convert from & to & divide by \\
\hline cubic meter & cubic foot (gas) & 0.02831685 \\
cubic meter & cubic yard & 0.7645549 \\
gram & troy ounce & 31.10348 \\
kilocalories per kilogram & Btu per pound & 20.556 \\
liter & barrel (oil) & 158.9873 \\
meter & foot & 0.3048 \\
meter & inch & 0.0254 \\
kilogram & pound & 0.4535924 \\
kilogram & troy ounce & 0.03110348 \\
kilometer & pounds per square foot & 4.882428 \\
metric ton & mile & 1.609347 \\
kilograms per square meter & ton (short) & 0.9071847 \\
square kilometer & acre & 0.004046873 \\
square kilometer & square mile & 2.589998 \\
\hline
\end{tabular}

${ }^{1}$ American Society for Testing and Materials (1980)

${ }^{2}$ Handbook of Chemistry and Physics (Weast, 1974, p. F-284) 


\section{CONTRIBUTORS}

\section{DEPARTMENT OF THE INTERIOR}

Bureau of Land Management

Gary Brougham

Joseph Dygas

Nolan Heath

Ruth Stockie

Minerals Management Service

Richard Newman

National Park Service

Kevin Meyer

U.S. Bureau of Mines

Steven Fechner

U.S. Fish and Wildlife Service

Marcus Horton

U.S. Geological Survey

Kenneth Bird

Kendell Dickinson

John Galloway

Terry Keith

Charles Moore

Jill Schneider

Gary Stricker

Ellen White

Department of Agriculture

U.S. Forest Service

Roger Griffin

Ginny Grove

Department of Energy

Steven Heintz

Rodney Malone

Harold Shoemaker 



\title{
1994 Annual Report on Alaska's Mineral Resources
}

\author{
Jill L. Schneider, Editor
}

\section{SUMMARY}

Section 1011 of the Alaska National Interest Lands Conservation Act (ANILCA) of 1980 requires that "On or before October 1, 1982, and annually thereafter, the President shall transmit to Congress all pertinent public information relating to minerals in Alaska gathered by the United States Geological Survey, Bureau of Mines, and any other Federal agency." This report has been prepared in response to that requirement.

This circular is the thirteenth in the series of annual mineral reports mandated by the ANILCA. The report provides information about current Alaskan mineral projects and events during 1993; the emphasis is on Federal activity. The report addresses both onshore and offshore areas of Alaska.

The U.S. Geological Survey (USGS), U.S. Bureau of Mines (USBM), and Minerals Management Service (MMS) are the principal Federal agencies that publish information about energy and mineral resources in Alaska. Their reports and data form the basis for decisions by other Federal agencies regarding land use, access, environmental impacts, and mining claim evaluation. The time required for sample analysis, data synthesis, and publication is lengthy; as a result, scientific reports are generally issued a year or more after initial sample and data collection. Other sources of information for this report include additional Federal and State publications, trade and professional journals, newspaper articles, presentations at public meetings and hearings, and press releases.

Information is provided for two broad categories of minerals: energy resources and nonfuel-mineral resources.

\section{ENERGY RESOURCES}

\section{OIL AND GAS}

Alaskan oil production in 1993 totaled 604.8 million barrels of oil and natural gas liquids, a decrease of 7.5 percent from 1992. This decrease follows the general de-

Manuscript approved for publication September 26, 1994. cline in Alaskan production that began in 1989 after a peak production of 738 million barrels in 1988. Alaska continued to provide about 25 percent of total United S'ates oil production. Dry natural gas production totaled 5.4 billion cubic meters, 5.3 percent below 1992's 5.7 billic n cubic meters. North Slope oil prices during the year averaged $\$ 15.97$ per barrel (West Coast), an 8-percent decline from the previous year. Prices ranged from a high of $\$ 18.21$ in May to a low of $\$ 13.10$ in December. The year's average price was the lowest since 1988, and the Decemter price was the lowest monthly figure since October 1988.

The Alaska Oil and Gas Conservation Commission issued 208 drilling permits in 1993, a 36-percent increase over the 153 permits issued in 1992. A total of 18 exploratory wells was active. Two oil discoveries were announced in northern Alaska, and one confirmed in Cook Inlet. Five State lease sales were held, three on the North Slope and two in Cook Inlet. High bonus bids totaled nearly $\$ 71$ million dollars for almost 1,457 square kilometers. About 95 percent of the bonus money was generated by the tv'o Cook Inlet sales. No Federal lease sales were held in 1993, but four lease sales are planned for 1996-1997.

In 1993, the State of Alaska received $\$ 6.6$ million in minerals revenues collected by the MMS from Federal public lands located within its borders. The MMs issued permits for 3,550 line-kilometers of seismic surveys in Outer Continental Shelf (OCS) waters. Cooperative studies in 1993 by the MMS and the Alaska Division of Geological and Geophysical Surveys (ADGGS) focused on the Prudhoe Bay area, the foothills of the Arctic I'ational Wildlife Refuge (Arctic NWR), and the western front of the Brooks Range. Continued studies on the OCS emphasized possible environmental effects following exploration activities and oil and gas drilling.

The USGS in 1993 continued its evaluation of oil potential on the North Slope. The USGS also continued to investigate the potential production of gas from hydrate complexes, released final details of the 1987 oil and gas assessment, conducted preliminary meetings for the next oil and gas assessment, and assembled a series of reports on the thermal history of Alaska.

The Bureau of Land Management (BLM) placed on hold plans for a possible oil and gas lease sale in the I 'ational 
Petroleum Reserve-Alaska (NPRA) and completed several oil and gas appraisals for land-exchange parcels. The BLM continued its Alaska Inspection and Enforcement program for leasehold oil and gas operations on producing Federal leases in the Cook Inlet Basin. Through the Joint Pipeline Office, the BLM monitors the Trans-Alaska Pipeline System in cooperation with seven other Federal and State agencies.

Mineral-related activities for the U.S. Fish and Wildlife Service (FWS) during 1993 included environmental monitoring, permit review and comment, and contaminant analysis both on and off refuges. On refuges, the FWS maintained oversight for remedial cleanup programs and issued nine special-use permits for exploration and development activities; the FWS also reviewed permit applications for oil and gas activities off refuges. Federal OCS environmental impact statements and State oil and gas lease sales were reviewed.

The FWS continued to respond to public and congressional inquiries regarding the ANILCA 1002 area, a 6,070-square-kilometer strip located on the coastal plain of the Arctic NWR. In 1992, the FWS completed a 5-year ecosystems study of the 1002 area that inventoried vegetation, water availability, birds, mammals, and fish. In 1993, several other investigations proceeded under the FWS continuing-studies program. The knowledge and information gained from these studies will be used to avoid, minimize, or rectify adverse impacts from surface developments, should they occur in the 1002 area.

In 1993, the National Park Service (NPS) commented on oil and gas lease sales scheduled near National Park units. The Department of Energy (DOE) continued to investigate technology for developing the gas-hydrate resources of northern Alaska.

\section{EXXON VALDEZ OIL SPILL}

The oil tanker Exxon Valdez ran aground on Bligh Reef on March 24, 1989, spilling 41.65 million liters (262,000 barrels) of Prudhoe Bay crude oil into eastern Prince William Sound. The oil eventually spread south and west as far as the Alaska Peninsula. Federal and State agencies continue to monitor and assess the long-term impact of the spill.

In 1993, the FWS maintained a strong role in the restoration studies program, concentrating primarily on marine birds and sea otters; response and clean-up activities were reduced from previous years. The FWS also participated in working groups to draft a restoration plan and to evaluate and rank privately owned lands within the oil spill area for conservation. A permit was issued to Exxon for sampling the intertidal zone in the Alaska Maritime NWR.

The MMS provided staff and some funding to assist in the cleanup and monitoring of the oil spill. In 1993, MMS researchers continued to collect information on the long-term social, economic, and cultural consequences of the spill.

Since the settlement of oil-spill litigation in 1991, the NPS has continued its activities in restoration planning and implementation of the settlement agreement. An oilpersistence survey conducted by the NPS in 1992 showed small amounts of oil remaining at more than 20 locations within the three parks affected by the spill.

\section{COAL AND PEAT}

Alaska's coal production increased 3.6 percent in 1993 to 1.44 million metric tons, worth $\$ 38.1$ million, and peat production, valued at $\$ 445,000$, increased to 55,051 cubic meters; coal and peat combined represented 9 percent of total mining production value in 1993. The State of Alaska invested $\$ 6.9$ million in the coal terminal at Seward, granted a 5-year permit for coal extraction at the Arctic Slope Regional Corporation's Aluaq Mine in northwestern Alaska, issued an air-quality permit for the Healy Clean Coal Project, and considered funding for a pilot project to test a new coal-slurry fuel technology. The fate of the Alaska Mental Health Land Trust, wl $: \mathrm{h}$ includes coal deposits in central Alaska, remained under litigation.

The USGS investigated coal-bearing strata on the Kenai Peninsula and on the western side of Cook Inlet. As part of the Colville Mining District study, the USBM contracted the ADGGS to evaluate the coal resources of southern NPRA. The NPS provided input to an air-quality mitigation agreement for the Healy Clean Cos' Project, located less than 6.5 kilometers from Denali National Park and Preserve (Denali NP\&P). The DOE published the final environmental impact statement for the Healy Clean Coal Project in December.

\section{URANIUM}

High exploration and development costs, plus low prices due to a surplus on the world uranium market, continue to prevent the development of Alaska's uranium resources. The domestic uranium industry vas declared nonviable for the ninth straight year. The USGS uranium/ radon research program was reduced in 199 $\hat{2}$ and will be phased out in 1994.

The FWS completed its environmental assessment for the remediation of the contaminated Project Chariot site near Cape Thompson. Under Federal and State oversight, all soil from the disposal mound was removed to the Nevada Test Site. Biological samples showed no remnant radioactive sources from the 1962 tracer study.

\section{GEOTHERMAL RESOURCES}

The greatest potential for geothermal erergy production in Alaska exists at Makushin Volcano ard the Geyser 
Bight geothermal area in the Aleutian Islands. No Federal geothermal research was funded in 1993.

\section{NONFUEL-MINERAL RESOURCES}

\section{METALLIC MINERALS}

The value of Alaska's metallic mineral production dropped 25 percent in 1993 to $\$ 343$ million, caused by a combination of depressed base-metal prices and reduced mine production; metallic minerals represented 77 percent of total mining production value. Exploration and development expenditures also declined an average of 7 percent from 1992 outlays. Zinc produced the highest revenue at $\$ 236.5$ million for 243,774 metric tons; combined gold, silver, and lead production was valued at $\$ 106.7$ million. The Red Dog Mine in northwestern Alaska supplied 64 percent of domestic zinc production in 1993. In April, the Kennecott Greens Creek silver-lead-zinc mine was shut down until base-metal prices recover. The number of active mineral properties in Alaska fell from 1992 levels to 20,705 Federal claims and 27,469 State claims.

Exploration and development of Alaska's mineral industry are focused on gold. The Fort Knox property near Fairbanks, and the Kensington and Alaska-Juneau mines near Juneau, are estimated to contain total reserves of 341 million grams of gold. Other gold properties under development are Nolan Creek in the Wiseman district of northern Alaska, Golden Summit and Ryan Lode near Fairbanks, Nixon Fork near McGrath, and the Jualin and El Nido properties in southeastern Alaska. Exploration for base metals includes the Pebble Copper deposit near Lake Iliamna and massive-sulfide polymetallic deposits on Prince of Wales Island.

The Alaska Mineral Resource Assessment Program (AMRAP) continues to be the focus of USGS geologic mapping and the assessment of undiscovered mineral resources in Alaska. In 1993, a statewide mineral-resource assessment at the scale of 1:2,500,000 was initiated for the purposes of compiling an Alaskan Resource Data File (ARDF), preparing regional maps showing mineralresource assessment tracts, and preparing quantitative estimates of undiscovered mineral resources in selected mineral-deposit types for selected tracts. USGS scientists also performed field studies, research, and report writing for mineral assessments of twenty-three 1:250,000-scale quadrangles. Specialized geologic studies were conducted on a detailed scale for 24 projects around the State. The USGS released numerous reports on geologic mapping, mineral-resource assessment, and specialized geologic studies of Alaska lands.

USGS researchers also performed site-specific studies on gold and other precious-metal deposits in the Fortymile Mining District in interior Alaska and in the Kenai and Chugach Mountains of south-central Alaska. Studies of mafic and ultramafic rocks include research on their associated strategic and critical mineral deposits of platinum, chromium, nickel, and cobalt. Mercury, as both a naturally occurring and a manmade environmental hazard, is being investigated in southwestern Alaska. Cooperative USGS programs with Russian scientific agencies, the State of Alaska, and the Canadian Geological Survey cont nued research on the metallogenesis, tectonic history, ard ophiolites of the Russian Far East, mainland Alarka, and western Canada. The study on mineral deposits of mainland Alaska and northeastern Russia was released in 1993; it was the first report in Western literature to broadly document significant Russian mineral deposits.

Fieldwork and data interpretation continued for the USGS Trans-Alaska Crustal Transect (TACT), a multidisciplinary study of the Earth's crust along a corritor from the Gulf of Alaska to the Arctic Ocean. The USG. is also involved with the USBM in two collaborative studies requested by other Federal agencies: for the BLM, an evaluation of the mineral potential of the Colville Mining District in southern NPRA was in its fourth and fnal year; for the USFS, an estimation of the mineral endowment of an area in the Chugach National Forest also is nearing completion.

In 1993, the USBM studied the environmental effects of submarine tailings disposal, published c neratingcost escalation factors for use in determining development feasibility of mineral deposits in Alaska, and compiled commodity-specific data sets that will allow the rapid analysis of mineral-related issues and policies. Ongoing USBM studies included the impacts of the permitting process and ecosystem-management concepts on mining and mineral development. Mineral resource inventories were started in two BLM planning units. The USBM continued mining district studies in northern and southeastern Alaska, site-specific mineral investigations of some strategic and critical minerals, inventory and evaluation of abandoned mine lands in Chugach National Forest, and miscellaneous research projects on mitigation of the environmental impacts of mining in northern climates.

A total of 11,212 Federal mining claims were on record with the BLM in Alaska during the 1993 assessment year. Two mineral patents covering 17 cla $m s$ were issued. Other ongoing activities include North Slope mineral assessment and mining claim patent examinations.

The NPS is currently processing four Plans of Operations for mining and mining access in three National Park units; mineral validity examinations were also conducted on 63 claims. Two mining properties in Denali NP\&P were purchased. Under the Mineral Land Restoration program, debris was removed from 12 former mine sites in 3 park units, and reclamation research continued in the J' antishna area of Denali NP\&P. Permits for eight AMRAP projects in seven park units were issued to the MMS, USBM, and USGS. The Cultural Resources Mining Inventory located 
30 new historic mining sites in 5 parks. Cadastral surveys were conducted to locate claims and claim boundaries within park units.

In 1993, the FWS monitored 127 mining claims on 8 wildlife refuges, issued 1 special-use permit for geologic studies in the Togiak NWR, and reviewed U.S. Army Corps of Engineers (ACE) permits for mining activities off refuges.

The U.S. Forest Service (USFS) received 51 Notices of Intent and 76 Plans of Operations for mineral activities in Alaska's national forests in 1993. A waste-rock storage site was approved at the Greens Creek Mine. Three mineral patent applications for claims in the Tongass National Forest are under review. The USFS and USBM conducted inventories of environmental and safety hazards on abandoned and inactive mining claims in the Tongass and Chugach National Forests.

\section{INDUSTRIAL MINERALS}

The production of sand, gravel, and building stone was valued at $\$ 64$ million; 12.3 million metric tons of sand and gravel and 3.1 million metric tons of building stone were quarried. Jade and soapstone production was valued at $\$ 20,000$. Industrial minerals represented 14 percent of total mining production value in 1993.

New barite deposits discovered by the USGS and USBM during the course of mapping in the central Brooks Range increased domestic reserves of that mineral by 50 percent. The USBM examined limestone and gravel resources in the Ketchikan Mining District and funded the ADGGS to map industrial mineral localities in the Colville Mining District.

The BLM made a number of mineral-materials sales totaling 177,122 cubic meters. The FWS approved three gravel extraction permits in the Izembek NWR, and one gravel sale in the Yukon Delta NWR. The USFS continued to sell sand, gravel, and quarried stone for use in the construction of timber-sale roads, breakwaters, and airports.

\section{INTRODUCTION}

Section 1011 of the Alaska National Interest Lands Conservation Act (ANILCA) of 1980 requires that "On or before October 1, 1982, and annually thereafter, the President shall transmit to Congress all pertinent public information relating to minerals in Alaska gathered by the United States Geological Survey, Bureau of Mines, and any other Federal agency." The U.S. Geological Survey (USGS) subsequently was delegated as the lead agency in responding to this requirement. This circular is the thirteenth in its series, synthesizing information made public in 1993. The report focuses on energy resources (oil, gas, coal, peat, uranium, and geothermal) and nonfuel-mineral resources (metallic and industrial minerals).

The USGS and the U.S. Bureau of Mines (USBM) are the principal Federal agencies that generate information about onshore mineral resources in Alaska; the Minerals Management Service (MMS) is the prime agency reporting on resource activities in Alaska's ccastal waters. Their data, analyses, and reports are used by other agencies for resolving questions on land use, access, environmental impacts, and mining claim evaluation.

As used herein, the term "public information" includes results of Federal projects as published in Government reports and professional and trade journals; oral presentations by representatives of Federal and State agencies and industry at symposia, conferences, and other public forums; and proceedings volumes, press releases, and newspaper articles. Many of the cited references are listed at the end of this report; however, most of the papers catalogued in the text are listed in appendix 1, wl ich inventories mineral reports published or released in 1993 or early 1994. Data from the State's annual summaries on Alaska's oil and mineral industries are cited in parts of this circular.

The next section describes the current mineral programs of land-management and other Federal agencies in Alaska. The roles of these agencies as they relate to minerals are discussed in appendix 2. The distribution of lands under Federal management is shown in figure 1.

\section{MINERAL PROGRAMS}

\section{DEPARTMENT OF THE INTERIOR}

\section{U.S. GEOLOGICAL SURVEY}

Section 1010 of ANILCA establishes the Alaska Mineral Resource Assessment Program (AMRAP) and directs the Secretary of the Interior to assess "the oil, gas, and other mineral potential on all public lands in the State of Alaska in order to expand the data base with respect to the mineral potential of such lands." To assist in meeting th: mandate of AMRAP, the USGS has undertaken systematic investigation of the State's mineral resources through four progressively more detailed levels of study. These studies are funded under the Mineral Resource Surveys program. Geologic studies at level I cover the whole State, and at level II cover large areas. Studies at level III draw on many geologic disciplines (fig. 2) to produce resource assessm?nts at scales of 1:250,000 and 1:125,000. Level IV research focuses on detailed studies of specific mining districts, mineral deposits, or topics relating to the genesis of mineral deposits. In 1993, level III studies were under way in 23 quadrangles, and 24 level IV studies were in progress.

USGS AMRAP publications are a key source of information about Alaska's geology and resource potential. 


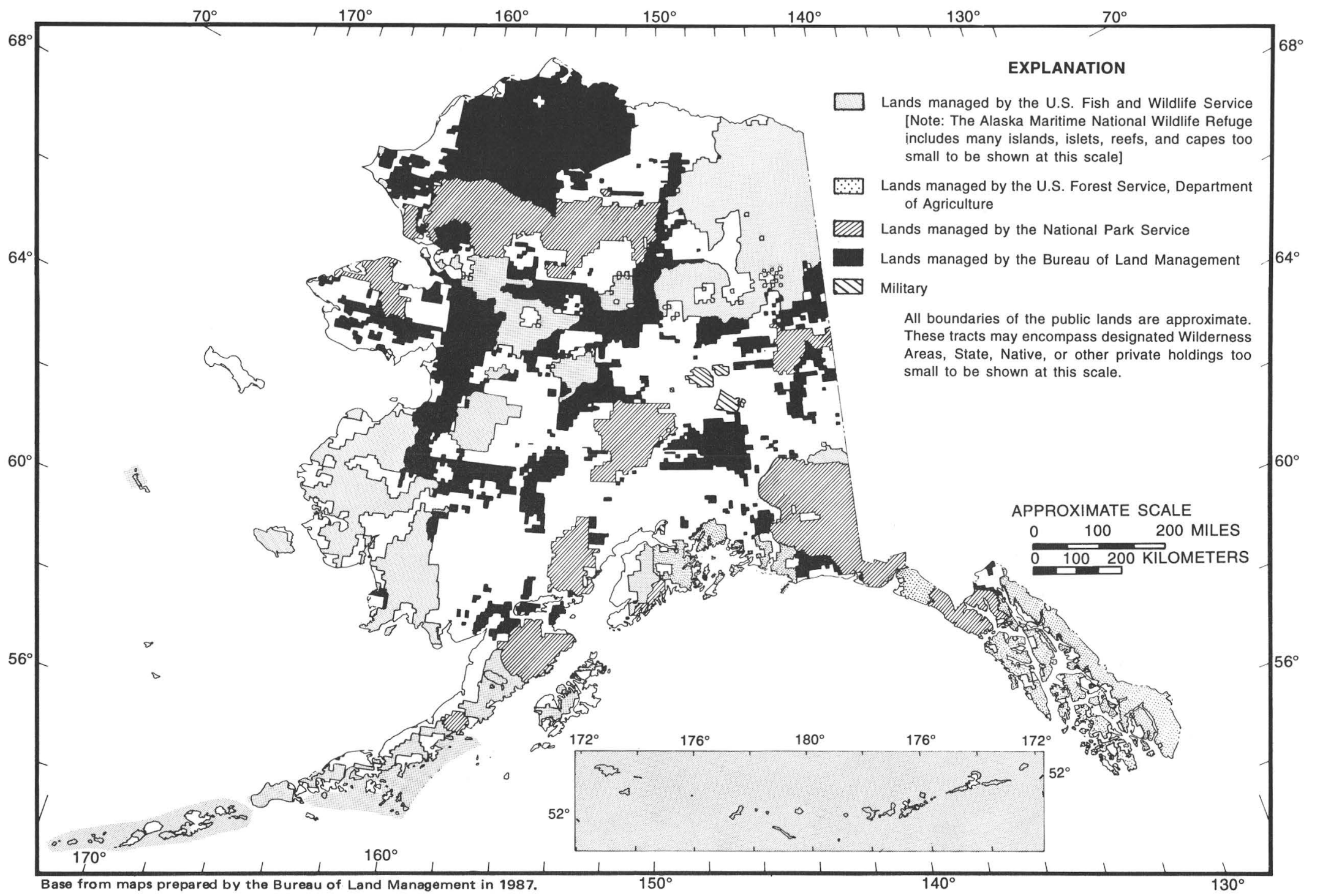

Figure 1. Federal land ownership in Alaska (boundaries as of June 1987). 
AMRAP studies are essential for the determination of the distribution and potential of national mineral and energy endowments, for the formulation of public policy affecting resource and land management, and for the improvement of resource-assessment technology in minimizing potential impacts from development. These studies, which develop the concepts, models, and techniques needed to identify new mineral deposits, are vital to the minerals-exploration industry.

In 1993, the USGS performed its resource-assessment work in Alaska through several programs: (1) the National Mineral Resource Assessment Program, which includes studies of undiscovered mineral resources on public lands; (2) the Development of Assessment Techniques

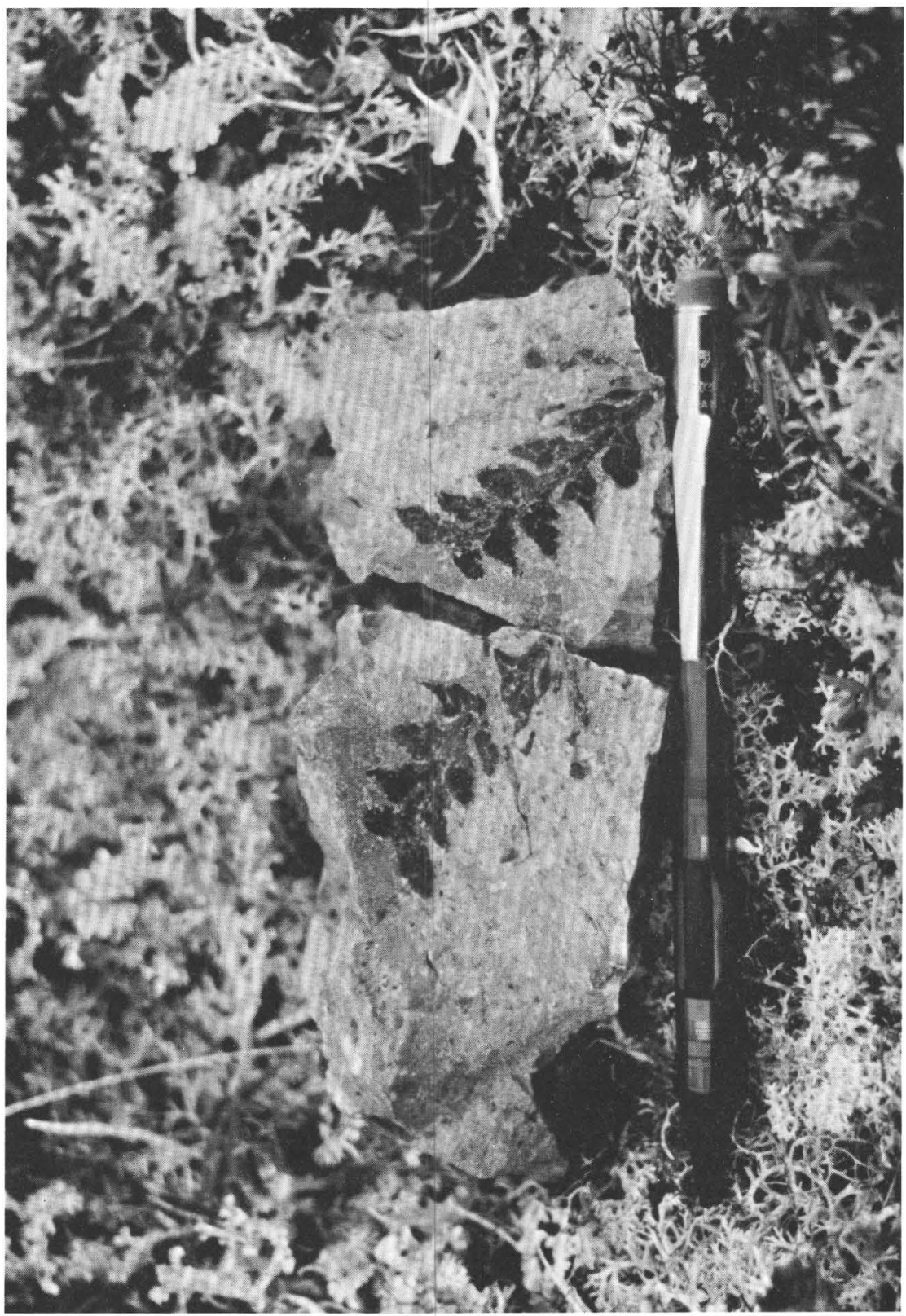

Figure 2. A fossil leaf from silicious sinter that caps a fossil hot spring deposit in the Russian Mission quadrangle. Identification of the fossil and its place in geologic time allows the age of the hot spring and its accompanying mineralization to be established. Paleontology (study of fossils) is one of many geologic disciplines employed in mapping and resource assessment. Photograph by M. Miller. 
Program, which has a goal of improving the ability to identify and evaluate mineral resources; (3) the Strategic and Critical Minerals Program, which identifies the potential of these resources to meet national military and economic needs; and (4) the Oil and Gas Investigations Program, which focuses on studies of petroleum-forming processes and potential source regions in order to produce reliable estimates of undiscovered petroleum resources. In addition, the Trans-Alaska Crustal Transect (TACT) program is a multidisciplinary approach to study the Earth's crust along a corridor from the Pacific Ocean to the Arctic Ocean. This program is coordinated with the Trans-Alaska Lithosphere Investigation, which utilizes earth scientists from the Alaska Division of Geological and Geophysical Surveys (ADGGS), the University of Alaska, other universities, and private industry. The mineral-related aspects of many of these programs are more fully described in later sections of this report.

Information for mineral deposits and occurrences in the United States and worldwide is available through computerized files of the USGS Mineral Resources Data System (MRDS). In Alaska, there are presently 4,155 records in one hundred 1:250,000-scale quadrangles throughout the State. Each record includes up to 200 pieces of information related to the identification, location, geology, deposit type, exploration and development, mine workings, commodity, production, reserves, resources, and references (Leonard and Huber, 1987). Geologic and deposit information from the Alaska MRDS files can be used to complement economically oriented data from the Minerals Availability System (MAS) computerized files of the USBM, discussed in the next section. Further MRDS information can be obtained from Ray Arndt, MRDS Project Chief, U.S. Geological Survey, 920 National Center, Reston, VA 22092-0001.

\section{U.S. BUREAU OF MINES}

During 1993, the Alaska Field Operations Center (AFOC) and various research centers of the USBM were active in the programs listed below; see appendix 2 for further information on the scope and nature of these programs.

Minerals availability.-The two computerized components of the minerals availability program are the MAS and the Mineral Industry Location System (MILS) data bases. The MAS contains information on reserve estimates, mineral extraction and beneficiation methodologies, environmental constraints on mining, and cost analyses for selected major mineral deposits. The MILS lists basic information on the identification and location of known mineral deposits.

Policy analysis.-The policy analysis program compiles analyses of mineral data with respect to local and national needs. Technical, institutional, political, social, and economic criteria are used to identify miner ${ }^{1}$ issues.

State mineral activities.-The USBM compiles and analyzes mineral data to report on activities and trends within Alaska's mining industry.

Mineral land assessment.-The USBM's major emphasis in Alaska has been the development of areal and commodity-oriented mineral assessments. Much of the work is focused on evaluations of mining districts, planning units of the Bureau of Land Management (RIM), and national forests. The evaluations include asses ments of type, quantity, distribution, reserves, and beneficiation characteristics of specific mineral deposits. The program also includes the investigation of deposits containing strategic and critical minerals and advanced materials and the analysis of hazards associated with abandoned mine lands.

Minerals research.-Minerals research by the USBM includes the improvement of mining techniques for maximizing mineral extraction while minimizing the environmental impacts of mining. Much of the USBM's work involves speculative, long-range research desigred to develop major technological improvements. Research in Alaska must also consider the State's distinctive climate and geologic conditions. Minerals research is administered by the nine USBM research centers in the cont guous 48 States or by Washington headquarters, as in the case of cooperative programs with universities such as the Mineral Institutes. Although partially funded by the USBM, the Mineral Institutes utilize university staff and facilities to conduct their work. Researchers from the Mineral Industry Research Laboratory of the University of Alaska at Fairbanks Mineral Institute were active in Alaska ir 1993. A primary goal of this research mission is the conmunication of USBM research results to industry, government, and the general public.

\section{MINERALS MANAGEMENT SERVICE}

The primary mission of the MMS in Alaska is the management of mineral resource exploration and development on Federal Outer Continental Shelf (OC:) lands. Management efforts are largely focused on leasing offshore areas for oil and gas exploration and development; the MMS also has the authority to lease OCS lands for mining of hard minerals.

Prior to an OCS lease offering, the MMS appraises the economic worth of leasable offshore lands and assesses environmental risks associated with development of resources on or beneath these lands. Followirg public review and comment, the MMS selectively makes these lands available through competitive OCS lease sales. The MMS regulates post-lease exploration, development, and production activities to ensure that operations are conducted in a safe and environmentally acceptable manner. The 
MMS inspects operations to ensure compliance with applicable laws, regulations, and lease terms. Finally, the MMS is responsible for the collection and accounting of royalty and rental revenues generated by the leased properties. At present, no minerals are being developed or produced on the Alaska OCS.

The MMS does not oversee the onshore exploration and development of Federal mineral commodities in Alas$\mathrm{ka}$ but is responsible for the collection of royalties, bonus payments, and lease rentals generated from onshore Federal and certain Native lands. Productive leases in the Beaver Creek and Swanson River oil and gas fields, as well as the Beluga, Cannery Loop, and Kenai gas fields, provide the bulk of this kind of revenue. The State of Alaska received $\$ 6.6$ million as its 1993 share of minerals revenues collected from such properties. Specific data on production and revenues from these fields may be obtained from the Minerals Management Service, Royalty Management, Lakewood, CO 80225.

The MMS also conducts regional studies of the geologic history and petroleum potential of Alaska's offshore basins for the National Resource Assessment, the MMSUSGS inventory of America's oil and gas resources. Results of these studies have been published as part of the MMS OCS report series. Appendix 1 lists these titles. Copies of the reports may be obtained from the MMS regional public information office in Anchorage.

\section{BUREAU OF LAND MANAGEMENT}

Principal BLM activities related to Alaska's onshore mineral and energy resources are (1) assessment of the mineral potential of BLM lands (fig. 1) and, through the planning process, identification of how the minerals can best be managed; (2) development of the terms and conditions, through the planning process and environmental review in accordance with the National Environmental Policy Act, for mineral exploration and development on BLM lands; (3) preparation of mineral-resource and economic evaluations to determine mineral values for lease sales, land exchanges, and Federal land disposal; (4) issuance and management of Federal leases in coordination with the responsible surface-management agency; (5) administrative maintenance and adjudication of Federal mining claims, determination of claim validity, critical review of Federal mineral validity reports, and issuance of mineral patents; (6) regulation of mining activities on BLM land to protect the environment; (7) regulation, permit and agreement approval, inspection of oil and gas leasehold operations, and enforcement of onshore orders for Federal leases producing oil and gas in the Cook Inlet Basin, in compliance with the BLM's National Inspection and Enforcement (I\&E) Strategy; (8) active participation in the State's Abandoned Well Site Closure Program for plugged and abandoned wells on Federal lands; and (9) protection of public mineral resources through an active program to identify, analyze, and study oil and gas drainage patterns.

The BLM is responsible for enforcing the environmental and technical stipulations of the Agreement and Grant of Right-of-Way for the Trans-Alaska Pineline System (TAPS); the overall goal of this effort is to maintain a continuous supply of energy via pipeline inteçrity and to ensure public safety and environmental protection by minimizing environmental impacts. In addition, the PLM issues land-use authorizations and conducts mineral-materials sales to support the operations and maintenanc: of TAPS, as well as preconstruction activities for the plenned natural-gas pipeline and other projects. The BLM has also provided assessments of mineral-potential studie? for other land-managing agencies, such as the U.S. Fish and Wildlife Service (FWS) and National Park Service (NPS), and for input to congressional initiatives.

Administrative responsibilities for minerals require close coordination with other surface-management agencies. Generally, in the case of onshore leases the BLM issues leases and integrates leasing with other land uses in cooperation with the surface-management agency. To assure proper surface and subsurface protections $a$ fter a lease is issued, the BLM enforces the regulations of Title 43, Code of Federal Regulations, Section 3160 (43 CFR 3160) and the lease stipulations and permit conditions for exploration and development activities.

\section{NATIONAL PARK SERVICE}

The NPS manages over 206,390 square kilometers in Alaska in 15 administrative units and 13 wild river segments. Under its congressional mandate, the NFS manages all units of the National Park System so as "t? conserve the scenery and natural and historic objects and wildlife therein and to provide for the enjoyment of the same in such manner and by such means as will leave them unimpaired for the enjoyment of future generations" (16 U.S.C. 1 et seq., NPS Organic Act). This mandate requires that the NPS manage park ecosystems at the highest possible level of natural resources stewardship. To hel? the NPS meet that goal, Congress passed the Mining ir the Parks Act (16 U.S.C. 1901 et seq.) in 1976, closirg all park units to the location of new Federal mining claims under the 1872 Mining Law.

The NPS minerals management program deals with a variety of minerals issues including mining claim management, navigability, access, hazardous waste. acquisition, reclamation, and non-Federal oil and gas and other non-Federal minerals. The goal of the NPS is to prevent adverse impacts to park resources from mineral activities.

The NPS carries out a variety of minerals-management functions through its offices at the national, regional, 
and park levels. The Alaska Regional Office, located in Anchorage, conducts a wide range of minerals management program activities in cooperation with park staffs through its Minerals Management Division. These activities include (1) mineral examinations to determine claim validity; (2) evaluation of proposed mining plans, including completeness determination, engineering analysis, impact assessment, and bonding; (3) compliance monitoring of approved operations; (4) aerial photography coverage and topographic mapping; (5) hydrologic monitoring; (6) inventory and cleanup of debris and hazardous materials on abandoned and inactive mine lands; and (7) reclamation research and planning. In a cooperative role, the Regional Office's Lands Resource Division conducts mineral and land valuation appraisals, administers property relocations, and negotiates acquisitions and donations; the Cultural Resources Division surveys historic and prehistoric sites and provides cultural resources protection for mining properties.

Guidelines for NPS management and regulations of mineral-related activities are identified in appendix 2 .

\section{U.S. FISH AND WILDLIFE SERVICE}

In Alaska, the FWS manages 306,562 square kilometers of National Wildlife Refuge lands and an additional 72,844 to 89,031 square kilometers of lands within the refuge boundaries that have been selected by the State or by Native corporations but have not yet been conveyed to them. The FWS is also responsible for research and monitoring of contaminants in fish and wildlife resources; for enforcement of Federal wildlife laws on and off refuges; and for coordination and comment under the Fish and Wildlife Coordination Act, which provides for review and comment of Federal permitting and development activities in waters and wetlands. This latter function includes the investigation, review, and comment on Federal permits and environmental impact statements.

Mineral activities may be allowed under permit on national wildlife refuges provided that the activity is compatible with the purposes for which the refuge was established. Under Section 810 of the ANILCA, if an activity would significantly restrict subsistence use of Federal lands, the agency must give notice and hold hearings to determine (1) that the restriction is necessary, (2) that a minimum amount of land is affected, and (3) that reasonable steps are taken to minimize adverse impacts upon subsistence uses and resources. The locations of the 16 national wildlife refuges in Alaska are shown in figure 3.

The FWS makes recommendations to other Federal agencies for mitigating adverse impacts to fish, wildlife, and habitats from federally constructed, funded, or permitted projects. The FWS reviews U.S. Army Corps of Engineers (ACE) permit applications under Section 404 of the
Clean Water Act of 1977, as amended, and under Section 10 of the Rivers and Harbors Act of 1899, as amended. These permit requirements apply to both public and private lands and waters.

The FWS manages migratory birds, listed threatened and endangered species, and certain marine mammals. When an agency is considering permit applications for exploration or development activity, that agency must determine if listed species are present within the area of activity. When a listed species is present, and it is determined that the proposed activity may adversely affect that species, the agency must consult with the FWS in accordance with the Endangered Species Act of 1973, as amended.

The FWS manages three marine mammals species in Alaska: polar bear, sea otter, and Pacific walrus. Section 101(a)(5) of the Marine Mammal Protection Act of 1972, as amended, authorizes the Secretary of the Interior to allow, via a permit, a U.S. citizen, engaged in a specified activity in a specified region, the incidental, but not intentional, taking of small numbers of marine mammals.

\section{DEPARTMENT OF AGRICULTURE}

\section{U.S. FOREST SERVICE}

Under a Memorandum of Understanding with the BLM, the U.S. Forest Service (USFS) jointly administers the general mining laws on National Forest System lands in Alaska (fig. 4). An example of this joint responsibility is the patent issued to Kennecott Greens Creek Mining Company for mining claims at the Greens Creek Mine near Juneau. The BLM issued this patent on the basis of favorable findings in a mineral report prepared by USFS mineral examiners.

The USFS cooperates with Department of the Interior (DOI) agencies, particularly the BLM, in issuing mineral leases and assuring mitigation of surface impacts of lease activities. The USFS also cooperates with State agencies and the private sector in development of energy and mineral resources on inholdings. One such inholding is the Bering River Coal Field, which is under consideration for possible development in a joint venture by the Chugach Alaska Corporation and others.

In Alaska, 93,000 square kilometers of land in 14 . Ranger Districts is administered by the USFS (fig. 1, table 1), whose regional office is in Juneau. Offices for the Chugach National Forest are located in Anchorage, Girdwood, Seward, and Cordova; Tongass National Forest offices are in Sitka, Ketchikan, and Petersburg.

\section{DEPARTMENT OF ENERGY}

In Alaska, the Department of Energy (DOE) is focusing its efforts on petroleum and coal resources. The DOE in 


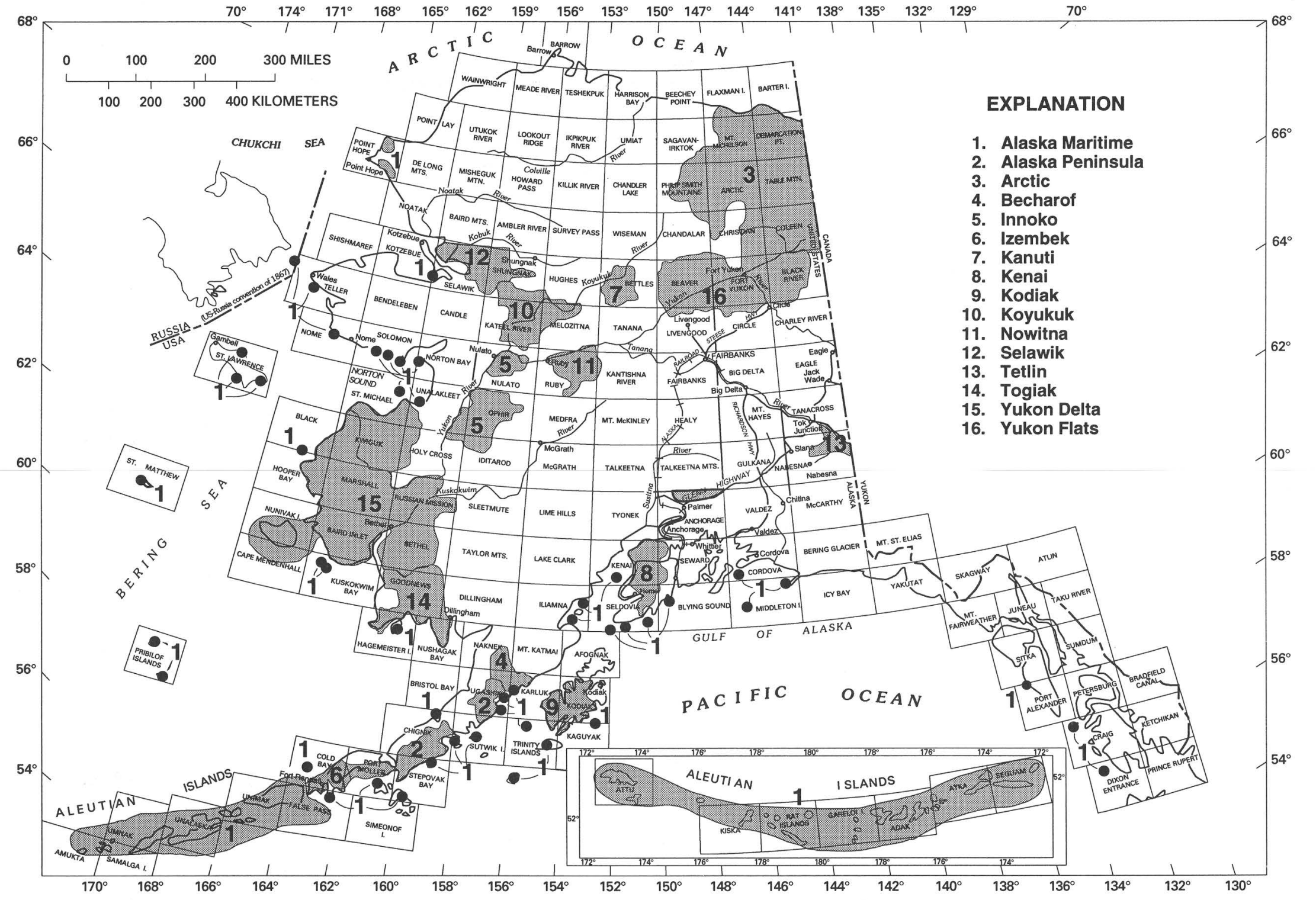

Figure 3. National wildlife refuges in Alaska. 1:250,000-scale quadrangles are outlined and labeled. 
Alaska administers congressional mandates relating to energy, monitors grants, and oversees contracts for energyresource studies. DOE funding helps support USGS resourceassessment studies and research by the University of Alaska.

To develop a better understanding of petroleum resources and to provide fundamental information to accelerate utilization of these resources, the DOE emphasizes resource and technological investigations that continue to expand the body of essential and basic scientific knowledge concerning conventional and heavy petroleums, shale oil, tar sands, and gas hydrates. The study of gas hydrates is a specific target of DOE research in Alaska.

The DOE is working to evaluate Alaskan coal in terms of its contribution to total national resources. Coal research currently centers on utilization methods suitable to Alaskan coals and conditions.

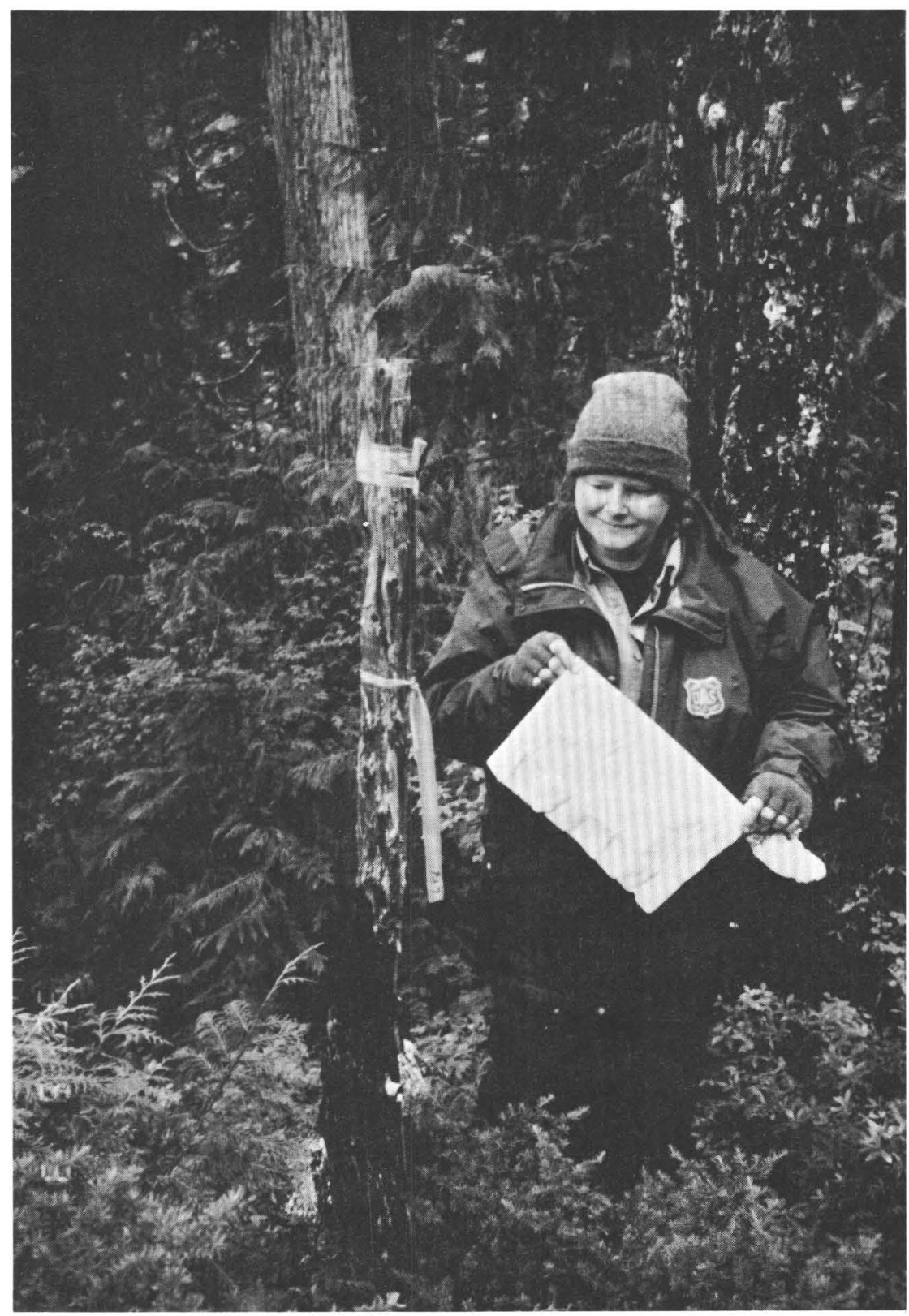

Figure 4. USFS mineral examiner inspects location notice on Tracy claim block for Tracy Partnership mineral patent examination, Tracy Arm-Fords Terror Wilderness, Tongass National Forest, southeastern Alaska. Photograph by R. Baer. 
Table 1. USFS Ranger Districts in Alaska.

\begin{tabular}{c}
\hline Chugach National Forest \\
Cordova Ranger District \\
Glacier Ranger District \\
Seward Ranger District \\
Tongass National Forest \\
Chatham Area \\
Admiralty Island National Monument \\
Hoonah Ranger District \\
Juneau Ranger District \\
Sitka Ranger District \\
Yakutat Ranger District \\
Stikine Area \\
Petersburg Ranger District \\
Wrangell Ranger District \\
Ketchikan Area \\
Craig Ranger District \\
Ketchikan Ranger District \\
Misty Fjords National Monument \\
Thorne Bay Ranger District
\end{tabular}

The DOE closed its regional office in Anchorage in 1985. Requests for information about DOE Alaskan activities should be addressed to the office listed below.

\section{CONTACTS FOR FURTHER INFORMATION}

\section{DEPARTMENT OF THE INTERIOR}

Bureau of Land Management

Tom Allen, State Director

Federal Building

222 West Seventh Avenue, No. 13

Anchorage, AK 99513-7599

Minerals Management Service

Judith C. Gottlieb, Regional Director

Alaska OCS Region

University Plaza Building

949 East 36th Avenue

Anchorage, AK 99508-4302

National Park Service

Robert Barbee, Regional Director

Alaska Regional Office

2525 Gambell Street, Room 107

Anchorage, AK 99503-2892

U.S. Bureau of Mines

Martin D. Conyac, Acting Chief

Alaska Field Operations Center

3301 C Street, Suite 525

Anchorage, AK 99503-3935

U.S. Fish and Wildlife Service

Walter O. Stieglitz, Regional Director

1011 East Tudor Road

Anchorage, AK 99503-6199

U.S. Geological Survey

L. David Carter, Chief

Branch of Alaskan Geology

4200 University Drive

Anchorage, AK 99508-4667

\section{DEPARTMENT OF AGRICULTURE}

U.S. Forest Service

Phil Janik, Regional Forester

Alaska Region

P.O. Box 21628

Juneau, AK 99802

\section{DEPARTMENT OF ENERGY}

Hydrocarbon Resources

Harold Shoemaker

Morgantown Energy Technology Center

P.O. Box 880, 3610 Collins Ferry Road

Morgantown, WV 26507-0880

\section{ENERGY RESOURCES}

\section{OIL AND GAS RESOURCES}

\section{OVERVIEW OF PRODUCTION AND PRICES}

Oil and gas remain the most valuable mineral-resource commodities produced in Alaska. Alaska's two oil-producing areas, the Arctic North Slope and the Cook Inlet, provided a total of 577.9 million barrels ( 1 barrel $=159$ liters) of oil, 26.9 million barrels of natural-gas liquids, 5.41 billion cubic meters of dry natural gas, and 73.72 billion cubic meters of casinghead gas in 1993 (table 2); 70.49 billion cubic meters of total gas production was reinjected for enhanced oil recovery. Oil and natural gas liquids declined 7.5 percent from 1992 levels; dry gas production decreased 4.2 percent. Daily oil production averaged 1.66 million barrels per day (bbl/d), 61,611 bbl/d less than in 1992, and well below peak production of 1.98 million bbl/d in 1988. About 98 percent of Alaska's oil comes from North Slope fields, and 99 percent of dry natural gas production occurs in the Cook Inlet area. Alaska provides about 25 percent of domestic oil production in the United States.

Alaska North Slope crude oil price-per-barrel reached a low of $\$ 13.10$ (West Coast) in December after peaking at $\$ 18.21$ in May (table 3). The average 1993 price was $\$ 15.97$ per barrel (West Coast), an 8-percent decline from the 1992 average price of $\$ 17.32$, and the lowest since 1988 (fig. 5). Alaska's treasury is especially vulnerable to crude oil prices because 85 percent of its current income is derived from royalties and taxes paid on State-owned oil and gas leases. Each $\$ 1$ change in the price of crude oil translates to approximately $\$ 150$ million gained or lost in State revenues.

\section{EXPLORATION}

PERMITS ISSUED

The Alaska Oil and Gas Conservation Commission issued 208 drilling permits in 1993, for 19 exploratory 
Table 2. 1993 Alaskan oil and gas production statistics.

[Data from Alaska Oil and Gas Conservation Commission Bulletin, February 1994; BBL, barrels; NGL, natural gas liquids; MCM, thousand cubic meters; DNG, dry natural gas; CHG, casinghead gas]

\begin{tabular}{|c|c|c|c|c|}
\hline Field & BBL Oil & BBL NGL & MCM DNG & MCM CHG \\
\hline \multicolumn{5}{|c|}{ North Slope } \\
\hline $\begin{array}{l}\text { Prudhoe Bay } \\
\text { Kuparuk River } \\
\text { Endicott } \\
\text { Point McIntyre } \\
\text { Milne Point } \\
\text { Walakpa } \\
\text { South Barrow } \\
\text { East Barrow }\end{array}$ & $\begin{array}{r}395,422,665 \\
115,165,968 \\
39,194,146 \\
7,519,290 \\
6,763,709\end{array}$ & $\begin{array}{r}25,223,207 \\
1,558,345 \\
75,411\end{array}$ & $\begin{array}{r}16,572 \\
12,493 \\
7,345\end{array}$ & $\begin{array}{r}63,715,521 \\
3,414,972 \\
3,416,272 \\
138,573 \\
98,674\end{array}$ \\
\hline & $564,065,778$ & $26,856,963$ & 36,410 & $70,784,012$ \\
\hline \multicolumn{5}{|c|}{ Cook Inlet } \\
\hline $\begin{array}{l}\text { McArthur River } \\
\text { Granite Point } \\
\text { Middle Ground Shoal } \\
\text { Swanson River } \\
\text { Trading Bay } \\
\text { Beaver Creek } \\
\text { West McArthur River } \\
\text { North Cook Inlet } \\
\text { Kenai } \\
\text { Beluga River } \\
\text { Ivan River } \\
\text { Stump Lake } \\
\text { West Fork } \\
\text { Lewis River } \\
\text { Pretty Creek } \\
\text { Sterling }\end{array}$ & $\begin{array}{r}6,635,660 \\
2,488,257 \\
2,155,550 \\
1,575,649 \\
742,237 \\
152,942 \\
97,250\end{array}$ & 66,030 & $\begin{array}{r}1,653,863 \\
251 \\
56,748 \\
62,458 \\
\\
178,214 \\
\\
1,289,239 \\
944,146 \\
898,741 \\
233,262 \\
22,032 \\
17,693 \\
10,853 \\
9,434 \\
197\end{array}$ & $\begin{array}{r}115,776 \\
68,950 \\
28,755 \\
2,704,126 \\
17,529 \\
1,191 \\
879\end{array}$ \\
\hline & $13,847,545$ & 66,030 & $5,377,131$ & $2,937,206$ \\
\hline Totals & $577,913,323$ & $26,922,993$ & $5,413,541$ & $73,721,218$ \\
\hline
\end{tabular}

Table 3. Fluctuation in price of Alaska North Slope crude oil, 1993.

[Data from Alaska Report; BP Exploration's Alaska North Slope contract crude oil price represents 95 percent of production. Contract price is set at beginning of each month and is $t$ ased on average of spot market price for prior month (Alaska Report, May 11, 1988). WC, delirered to West Coast; GC, delivered to Gulf of Merico]

\begin{tabular}{|c|c|c|}
\hline \multirow{2}{*}{ Date } & \multicolumn{2}{|c|}{ Price per barrel } \\
\hline & WC & GC \\
\hline $\begin{array}{c}(12 / 2 / 92) \\
1 / 6 / 93 \\
2 / 3 / 93 \\
3 / 3 / 93 \\
4 / 6 / 93 \\
5 / 5 / 93 \\
6 / 2 / 93 \\
7 / 7 / 93 \\
8 / 4 / 93 \\
9 / 8 / 93 \\
10 / 6 / 93 \\
11 / 3 / 93 \\
12 / 8 / 93 \\
(1 / 5 / 94)\end{array}$ & $\begin{array}{r}(17.44) \\
\$ 16.33 \\
15.61 \\
16.78 \\
17.37 \\
18.21 \\
17.45 \\
16.05 \\
14.89 \\
15.45 \\
14.94 \\
15.44 \\
13.10 \\
(10.38)\end{array}$ & $\begin{array}{r}(18.26) \\
\$ 17.19 \\
16.59 \\
17.90 \\
18.34 \\
18.30 \\
17.99 \\
17.00 \\
15.89 \\
16.22 \\
15.51 \\
16.02 \\
14.32 \\
(12.28)\end{array}$ \\
\hline 1993 average price & $\$ 15.97$ & $\$ 16.79$ \\
\hline
\end{tabular}

wells, 164 development wells, and 25 service wells. This is a 36-percent increase over the 153 permits issued in 1992. Most of the approved wells were scheduled for the North Slope; only 7 exploratory wells and 13 development wells were planned for Cook Inlet.

\section{DRILLING ACTIVITY}

Eighteen exploratory wells were active in 1993, two more than the year before: 11 wells on the North Slope, 3 in the adjacent Beaufort Sea, and 4 in the Cook Inlet region (fig. 6; table 4). One well on the North Slope intercepted a new oil pool, but the other exploratory wells were plugged and abandoned.

Cook Inlet.-ARCO Alaska and Phillips Petroleum drilled 3 delineation wells (South Cook Inlet-State 2, South Cook Inlet-State 3, Sunfish 3) in the 40-kilometer-long Sunfish prospect in northern Cook Inlet to explore the potential of their 1991 oil and gas discovery. The 1991 Sun- fish 1 well was drilled in the northern end of the prospect and flowed 1,100 barrels of oil and 28,317 cubi- meters of gas per day. ARCO confirmed the Sunfish discovery in 1993 and announced that its 1992 North Foreland-State 1 well flowed 3,610 barrels of oil and 84,951 cubi : meters of gas per day (Alaska Report, February 3, 1993). The South Cook Inlet-State wells were drilled in the soutl srn end of the prospect and did not encounter commercial hydrocarbons (Alaska Report, December 21, 1993).

Stewart Petroleum drilled a second exploratory well in its West McArthur River discovery on the w'ss side of Cook Inlet. The West McArthur River field may contain as much as 100 million barrels of oil and 991 million cubic meters of gas (Alaska Report, April 20, 1994). The Sunfish 1 and West McArthur River 1 wells were the first Cook Inlet oil discoveries since 1965.

North Slope.-ARCO Alaska announced a new onshore pool discovery after its North Prudhoe Pay-State 3 well tested at 3,000 bbl/d from the Ivishak Formation (Alaska Report, April 28, 1993). ARCO also announced 
the new offshore West Beach pool, discovered by the West Beach-State 4 well in 1991; ARCO began producing from the West Beach pool in April 1993.

Beaufort Sea.-Three wells were drilled pursuant to ARCO Alaska's 1992 oil discovery in the Kuvlum prospect, located in Camden Bay in the eastern Beaufort Sea. The discovery well, OCS-Y-0866, tested at 3,400 barrels of oil and 55,635 cubic meters of gas per day. Results from the 1993 follow-up wells (Kuvlum 2, Kuvlum 3, and Wild Weasel 1) indicated that the discovery is smaller than the one billion barrels of recoverable oil needed to be commercially viable (Anchorage Daily News, October 7, 1993). ARCO's partners in the discovery include Union Texas Petroleum, Phillips Petroleum, Total Minatome, Murphy Oil U.S.A., and Mobil Exploration and Production U.S. (Rintoul, 1993).

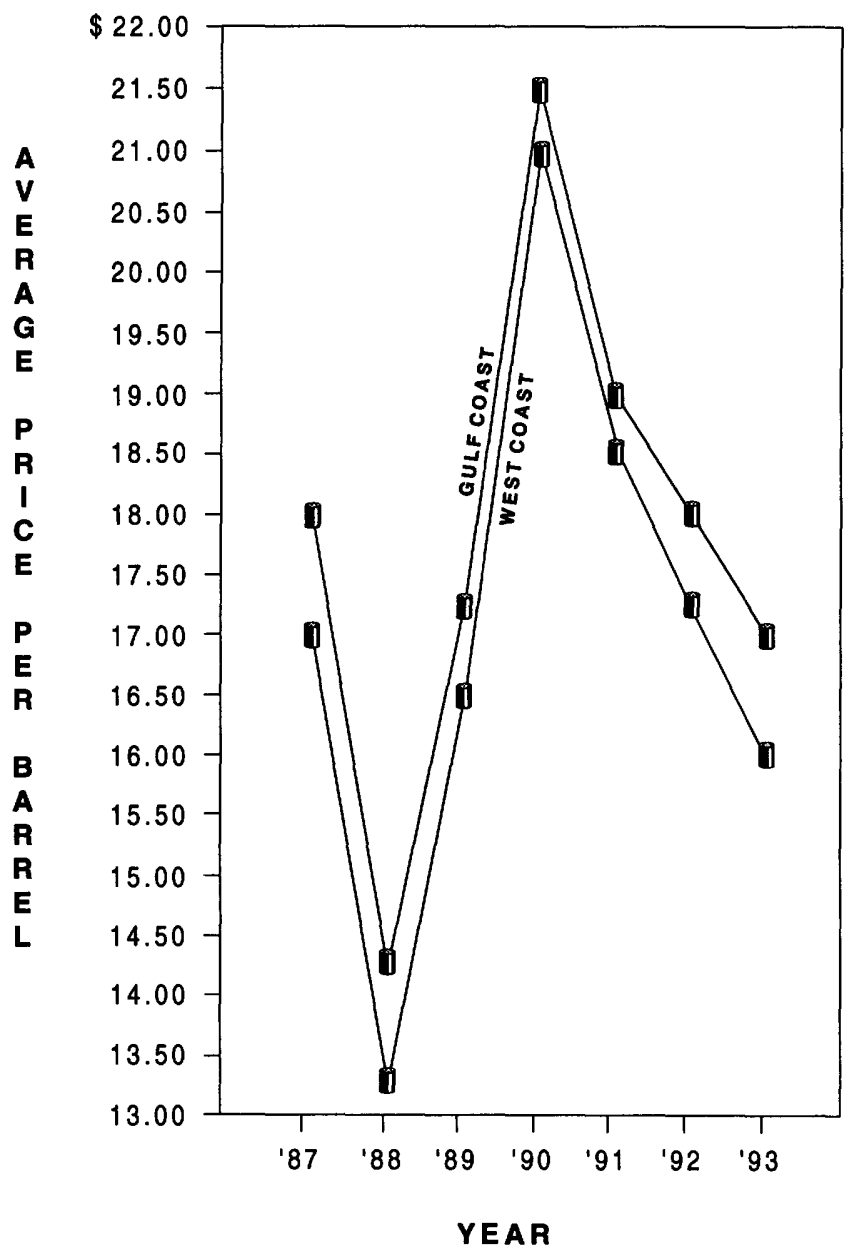

Data from Alaska Report.

Figure 5. Fluctuation in annual average price of Alaska North Slope crude oil, 1987-1993.

\section{GEOPHYSICAL SURVEYS}

Federal and State permits for the 1993 winter drilling season were approved for 5,633 line-kilcmeters of seismic exploration: 5,150 kilometers on the North Slope and Beaufort Sea, 322 kilometers in Cook Inlet, and 161 kilometers in the Gulf of Alaska near Cordora (Alaska Report, March 31, 1993).

\section{PRODUCTION}

During 1993, there were 1,627 producing oil wells in the State, up from 1,599 wells in 1992; 113 gas wells and 629 service wells were also active (Alaska Oil and Gas Conservation Commission Bulletin, February, 1994). Of these, 147 development wells and 24 service wells were completed in 1993: 137 development and 23 service wells on the North Slope, and the rest in the Cook Ir $^{1}$ et region. Little information on these wells has been released to the public, but some data are made available through the Alaska Oil and Gas Conservation Commission's morthly bulletins and the Petroleum Information Corporation's weekly Alaska Report.

\section{NORTH SLOPE}

Of the 604.8 million barrels of oil and natural gas liquids produced in 1993, 97.7 percent came from fields on the North Slope. Production from Prudhoe Bay, Kuparuk River, and Endicott combined accountet for 95.3 percent of the oil and natural gas liquids produc ad.

Prudhoe Bay.-The Prudhoe Bay field, froducer of 69.6 percent of the State's oil, showed a 50-mi'lion-barrel decline in oil, down 10.6 percent from 470.5 million barrels in 1992 to 420.6 million barrels in 1993. By the end of 1993, the Prudhoe Bay field had produced a cumulative total of 8.5 billion barrels of oil and natural gas liquids and 526 billion cubic meters of casinghead gas. This gas is now the limiting factor on Prudhoe oil output because, as the field ages, more gas and water are produced along with the oil; these fluids must be separated before the oil goes into the pipeline. So much gas is now produced at Prudhoe Bay that facilities for separation and reinjection into the reservoir are operating at full capacity. The pres $?$ nt GHX-1 gas-handling facility is already the largest in the world, reinjecting about 141.6 million cubic meters of gas through 22 wells each day. A second gas-handling facility, GHX-2, was installed in 1993; GHX-2 is expected to in rease production by another 100,000 barrels of oil per day when the plant comes on line in 1995 and to allow an additional 330 to 450 million barrels of oil to be recovered frcm the field (Oil and Gas Journal, 1993a). The GHX-2 facility will increase gas-handling capability from 147.2 million cubic meters to 212.4 million cubic meters per day. The original 


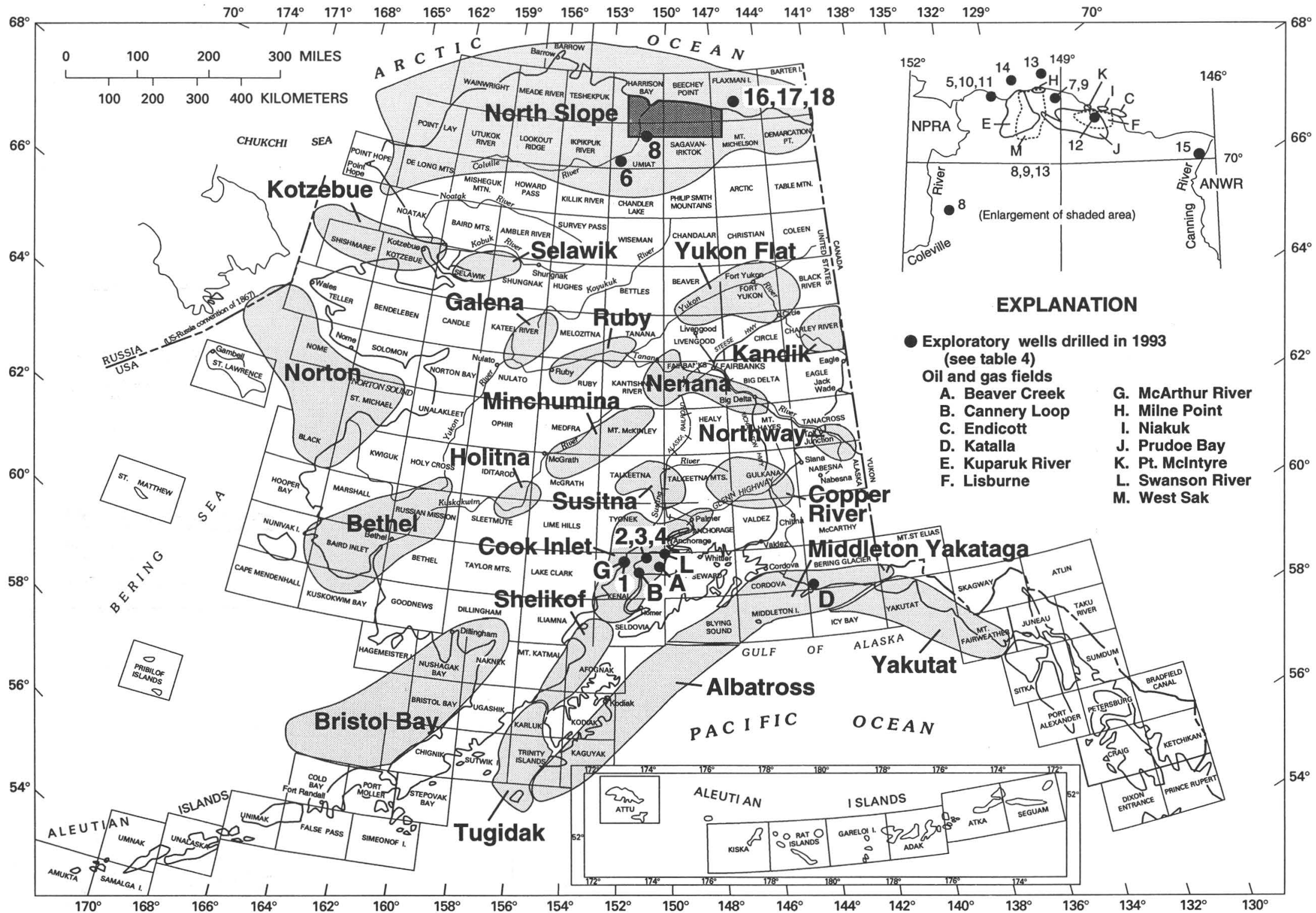

Figure 6. Locations of exploratory oil wells drilled in 1993, oil and gas fields, and possible petroleum-bearing sedimentary basins (outlined). Basins adapted from Kirschner (1988). 1:250,000-scale quadrangles are outlined and labeled. 
Table 4. Alaska exploratory oil wells drilled in 1993.

[Data from Alaska Oil and Gas Conservation Commission and Minerals Management Service; see figure 6 for locations. Locations for onshore and State offshore wells given in section-township-range; SM, Seward Meridian (Cook Inlet); UM, Umiat Meridian (North Slope). Locations for Federal offshore wells given by latitude and longitude. ARCO-AK, ARCO Alaska; BPX, BP Exploration, P\&A, plugged and abandoned]

\begin{tabular}{llllc}
\hline Well & & & Total & Date \\
No. Company & Well name & API No. & Location & $\begin{array}{c}\text { depth completed } \\
\text { (meters) }\end{array}$ \\
\hline
\end{tabular}

Onshore and State offshore waters

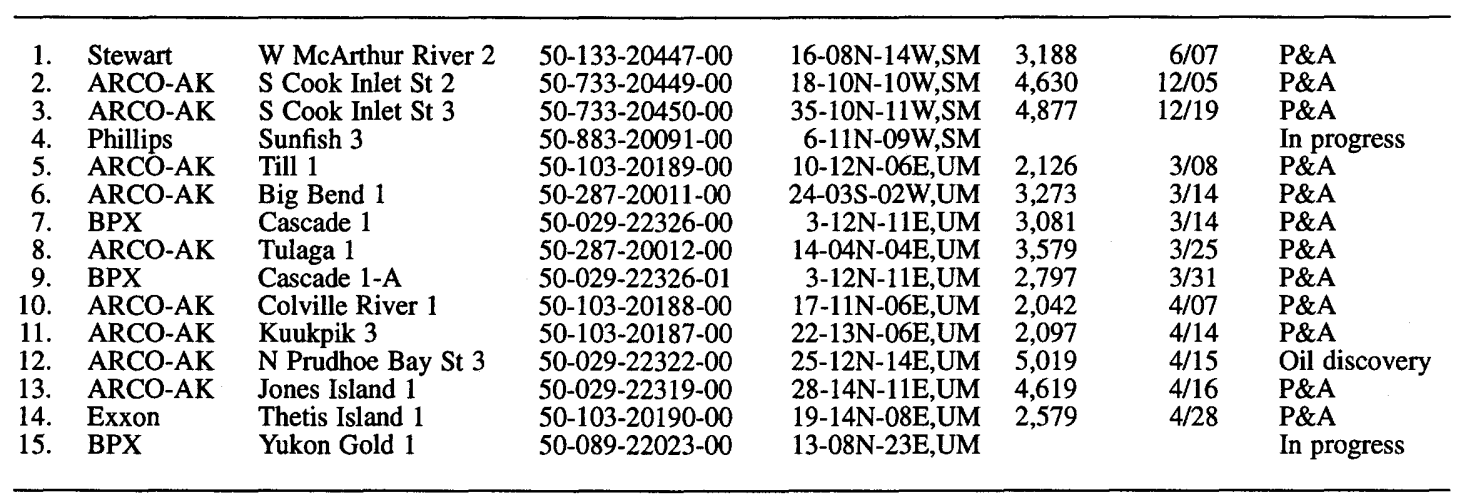

Federal offshore waters

\begin{tabular}{|c|c|c|c|c|c|c|c|}
\hline 16. & ARCO-AK & $\begin{array}{l}\text { OCS-Y-0856 } \\
\text { (Kuvlum 2) }\end{array}$ & $55-171-00009$ & $\begin{array}{r}70^{\circ} 18^{\prime} 36^{\prime \prime N} . \\
145^{\circ} 32^{\prime} 19^{\prime \prime} \mathrm{W} .\end{array}$ & 3,391 & $8 / 28$ & P\&A \\
\hline 17. & ARCO-AK & $\begin{array}{l}\text { OCS-Y-1597 } \\
\text { (Wild Weasel 1) }\end{array}$ & $55-171-00011$ & $\begin{array}{r}70^{\circ} 13^{\prime} 22^{\prime \prime} \mathrm{N} . \\
145^{\circ} 29^{\prime} 57^{\prime \prime} \mathrm{W} .\end{array}$ & 2,839 & $10 / 01$ & P\&A \\
\hline 18. & ARCO-AK & $\begin{array}{l}\text { OCS-Y-0866-2 } \\
\text { (Kuvlum 3) }\end{array}$ & $55-171-00010$ & $\begin{array}{r}70^{\circ} 19^{\prime} 37^{\prime \prime N} \text {. } \\
145^{\circ} 24^{\prime} 15^{\prime \prime} \mathrm{W} .\end{array}$ & 2,438 & $10 / 05$ & P\&A \\
\hline
\end{tabular}

estimate for oil recovery from the 24-billion-barrel Prudhoe Bay field was 9.4 billion barrels, but with water flooding, high-pressure fracturing, and gas reinjection, estimates for total recovery are now about 12 billion barrels.

The new West Beach pool, announced by ARCO in early 1993, was placed into production during April, yielding 3,000 bbl/d of oil from the West Beach-State 4 discovery well. Located between the Lisburne pool and the Point McIntyre field, West Beach was discovered in 1991 and is jointly owned by ARCO and Exxon U.S.A. The pool is estimated to contain 12 million to 65 million barrels of oil and 283 million to 1.6 billion cubic meters of gas in the Kuparuk sand reservoir. Produced oil is delivered to an existing Lisburne drillsite through a new 3.2-kilometerlong pipeline. Output for 1993 totaled 726,140 barrels of oil and natural gas liquids.

Kuparuk River.-In 1993, the Kuparuk River field joined the ranks of only 14 other oil fields in the United States which have produced a cumulative total of more than one billion barrels of oil (Alaska Journal of Commerce, June 14, 1993). Kuparuk River is the second largest domestic oil producer after the Prudhoe Bay field, producing about $315,000 \mathrm{bbl} / \mathrm{d}$. For the year, the field produced 115.2 million barrels of oil, down 3.3 million bar- rels (2.8 percent) from 1992. There are now 381 producing wells out of a total of 700 drilled in the field. Production from this field was originally expected to peak at $250,000 \mathrm{bbl} / \mathrm{d}$ with ultimate recovery of 1.2 billion to 1.5 billion barrels, but engineers now expect production to remain in the 300,000-bbl/d range through 1997 and to recover a total of 1.8 billion to 1.9 billion barrels.

Endicott.-The Endicott field produced 40.8 millions of barrels of oil and natural gas liquids in 1993, a drop of 2.3 million barrels (5.4 percent) from the previous year. The Endicott field has produced a cumulative total of 248.6 million barrels of oil and natural gas liquids.

Point McIntyre.-The Point McIntyre field, located beneath the waters of Prudhoe Bay, was discovered by ARCO Alaska in 1988 and began production in October of 1993; the field's recoverable reserves are estimated at 340 million barrels (Alaska Report, April 6, 1993). Ownership of the field was settled in 1993: Exxon, 37 percent; BP Exploration, 33 percent; and ARCO, 30 percent; ARCO is the field's operator. Total development costs are targeted at $\$ 700$ million (Alaska Report, May 13, 1992); approximately $\$ 300$ million have been spent to date. During 1993 , 7.6 million barrels of oil and natural gas liquids were produced from the field. Initial production was expected to 
begin at a rate of about $40,000 \mathrm{bbl} / \mathrm{d}$, increasing to more than $110,000 \mathrm{bbl} / \mathrm{d}$ at peak production. Taxes and royalties from this field are expected to provide about $\$ 80$ million per year to the State treasury (Rintoul, 1993).

Milne Point.-Production from the Milne Point field was 6.76 million barrels of oil in 1993. The field is expected to recover 250 million barrels of the estimated 1.2 billion barrels of in-place oil. Conoco was the field's operator, but the company traded all its interest in North Slope holdings to British Petroleum in late 1993 and no longer operates in Alaska (Alaska Journal of Commerce, November 15, 1993).

Niakuk.-The Niakuk field is located in the eastern part of Prudhoe Bay and is scheduled for limited oil production beginning in early 1994 (Alaska Business Monthly, October 1993). Construction of roads and the production pad and drilling of production wells were begun in 1993. Development costs are estimated at $\$ 130$ million, and the field is expected to produce 54 million barrels of oil and $\$ 150$ million in State taxes and royalties over the next 15 years. Development, through extended-reach drilling from an onshore production facility at Heald Point, will require 14 wells, manifold and test separator modules, and pipeline connections to the Lisburne production system (Alaska Journal of Commerce, August 30, 1993). The Niakuk field was discovered in 1985 and is owned entirely by BP Exploration Alaska.

Walakpa.-The Walakpa gas field was brought into production in 1992 to help supply Barrow's energy demands. The field produced 16.57 million cubic meters of gas in 1993, providing 45.5 percent of the total gas consumed by the village during the year; the South Barrow and East Barrow gas fields supplied the remainder. Walakpa gas reaches Barrow via a 26-kilometer-long pipeline that was completed in 1992.

\section{COOK INLET}

The Cook Inlet region produced 99.3 percent of the State's dry natural gas in 1993. The McArthur River, North Cook Inlet, Kenai, and Beluga River fields produced a combined 4.79 billion cubic meters of gas, 89 percent of the region's 5.4 billion cubic meters (table 2). The four main oil producers in the area are McArthur River, Granite Point, Middle Ground Shoal, and Swanson River, producing 12.95 million barrels of oil and natural gas liquids. Cook Inlet oil production peaked in 1970 at $237,000 \mathrm{bbl} / \mathrm{d}$, but now produces only about $40,000 \mathrm{bbl} / \mathrm{d}$. However, development of ARCO's Sunfish discovery would increase Cook Inlet oil production, and other companies have announced significant expenditures to maintain or increase production from existing fields.

West McArthur River.-Stewart Petroleum began producing oil from its West McArthur River 1 discovery well in August 1993. By year's end, the field had produced
97,250 barrels of oil, 878,728 cubic meters of casinghead gas, and 100,257 barrels of water from the Herlock reservoir. Currently, the oil produced is transportec' by tanker truck to Marathon Oil's Trading Bay facility, then purchased by Unocal. Stewart announced plans tc build two 4.5-kilometer-long pipelines: one 0.2-meter-diameter oil pipeline with a $25,000-\mathrm{bbl} / \mathrm{d}$ capacity plus one 0.1 -meterdiameter gas pipeline with a 1.13-million-cubic-meter-perday capacity. When fully developed, the field will have five producing wells and one disposal well. To date, $\$ 36$ million has been invested in this field; total development costs may reach $\$ 100$ million. Royalties and taxes to the State may be as high as $\$ 250$ million over the life of the field (Alaska Report, April 20, 1994).

Drilling platforms.-Unocal announced plans to invest $\$ 119$ million to upgrade facilities and drill new wells from the Baker, Dillon, Anna, and Bruce platforms in Cook Inlet. As many as 20 new wells are scheduled to be drilled over the next several years in the expactation of adding as many as $11,000 \mathrm{bbl} / \mathrm{d}$ of oil to the existing 4,000 bbl/d (Alaska Journal of Commerce, February 8, 1993).

\section{LEASE SALES}

State of Alaska.-The State of Alaska held six lease sales, four on the North Slope and two in Cook Inlet, during 1993. High bids totaled $\$ 70,675,460$ in bor's monies for 1,455 square kilometers. The two Cook Inlet sales accounted for nearly 95 percent of the bonus money.

The Cook Inlet 76 and Cook Inlet Exempt 67A-W sales drew high bids totaling $\$ 67.7$ million fo* 69 tracts covering 1,098 square kilometers. Both sales, dominated by the ARCO Alaska-Phillips Petroleum partnorship, offered acreage near the Sunfish discovery. Sale 76 brought in $\$ 65.3$ million and was the third most successful State sale ever held.

The Nanushuk 77, Kuparuk Uplands Exempt 70AW, and Colville River Exempt $75 \mathrm{~A}$ sales on the North Slope drew high bids of $\$ 2,972,429$ for 357 square kilometers. ARCO Alaska was the only successful bidder at Nanushuk 77, acquiring all 185 square kilometers that form a block approximately 96.6 kilometers south of the Kuparuk River oil field. In Kuparuk Upland's Exempt $70 \mathrm{~A}-\mathrm{W}$, a partnership of BP Exploration Alaska and Amerada Hess was the high bidder on five of the eight tracts that received bids. Colville River Exempt $75 \mathrm{~A}$ offered acreage jointly owned by the State and the Arctic Slope Regional Corporation. A partnership of ARCO and BP Exploration acquired the top tract with a bon's bid of $\$ 149,856$ for 7.8 square kilometers located 4.8 kilometers south-southeast of ARCO's 1992 Fiord discovery that flowed more than 1,000 barrels of oil per day.

No bids were submitted in the North Slope Foothills 57 lease sale. This sale offered 196 tracts covering 4,181 square kilometers in the foothills of the Brooks Range, 
Table 5. Alaska Outer Continental Shelf leases and wells drilled, 1976-1992.

[DST, Deep Stratigraphic Test well]

\begin{tabular}{|c|c|c|c|}
\hline $\begin{array}{l}\text { Planning area } \\
\text { (sale dates) }\end{array}$ & $\begin{array}{c}\text { Number } \\
\text { of tracts } \\
\text { leased }\end{array}$ & $\begin{array}{l}\text { Number } \\
\text { of wells } \\
\text { drilled }^{1}\end{array}$ & $\begin{array}{c}\text { Number } \\
\text { of active } \\
\text { leases }\end{array}$ \\
\hline $\begin{array}{l}\text { Beaufort Sea } \\
\quad(1979,1982,1984,1988,1991)\end{array}$ & 631 & 29 & 189 \\
\hline $\begin{array}{l}\text { Chukchi Sea } \\
(1988,1991)\end{array}$ & 378 & 4 & 126 \\
\hline $\begin{array}{l}\text { Cook Inlet Basin } \\
\quad(1977,1981,1982)\end{array}$ & 100 & $\begin{array}{l}14 \\
(1 \mathrm{DST})\end{array}$ & 0 \\
\hline $\begin{array}{l}\text { Gulf of Alaska } \\
(1976,1980,1981)\end{array}$ & 112 & $\begin{array}{c}13 \\
(1 \mathrm{DST})\end{array}$ & 0 \\
\hline $\begin{array}{l}\text { Kodiak Shelf } \\
\text { (no sales held) }\end{array}$ & 0 & $\begin{array}{c}6 \\
\text { (6 DST) }\end{array}$ & 0 \\
\hline $\begin{array}{l}\text { Navarin Basin } \\
\text { (1984) }\end{array}$ & 163 & $\begin{array}{c}9 \\
(1 \mathrm{DST})\end{array}$ & 2 \\
\hline $\begin{array}{l}\text { North Aleutian Basin } \\
\end{array}$ & 23 & $\left(\begin{array}{c}1 \\
(1 \mathrm{DST})\end{array}\right.$ & 23 \\
\hline $\begin{array}{l}\text { Norton Basin } \\
\text { (1983) }\end{array}$ & 59 & $\begin{array}{c}8 \\
(2 \mathrm{DST})\end{array}$ & 0 \\
\hline $\begin{array}{l}\text { St. George Basin } \\
\text { (1983) }\end{array}$ & 96 & $\begin{array}{c}12 \\
\text { (2 DST) }\end{array}$ & 6 \\
\hline
\end{tabular}

\footnotetext{
${ }^{1}$ Total includes both exploratory and DST wells.

${ }^{2}$ Includes Lower Cook Inlet and Shelikof Straits.

${ }^{3}$ Leases currently under 1-year moratorium and concurrent 1-year suspension of operations until September 30, 1994.
}

approximately 161 kilometers south of Prudhoe Bay. The lack of bids may have reflected the oil companies' anticipation of new State legislation regarding exploration licensing (Alaska Report, September 22, 1993).

Federal Government.-No federal lease sales for oil and gas were held in 1993. The MMS 5-year lease schedule includes four sales to be held in 1996 and 1997.

\section{TRANSPORTATION}

Almost 10 billion barrels of oil have been transported to the Valdez terminal through the TAPS since it was finished in 1977. Average daily throughput was 1.6 million barrels in 1993, down from a high of 2.2 million bbl/d in 1988. Because North Slope production is declining, measures will need to be taken to extend the economic viability of TAPS. Cost-cutting proposals include temporary idling and eventual shutdown of one or more pump stations. As less oil flows through TAPS, less power is needed to move it along the 1,290-kilometer route. Alyeska Pipeline Service Company tested TAPS to see if Pump Station 7 was needed for oil transport at present volumes (Alaska Report, March 30, 1994). Projections suggest that Pump Station 2 could be shut down when TAPS is carrying about 1.5 million $\mathrm{bbl} / \mathrm{d}$ of oil and, by the turn of the century, Pump Stations 5, 8, 10, and 12 are likely to go on "standby" or "temporarily abandoned" status. Each pump station
Table 6. Bonus bids received from lease sales on Alaska Outer Continental Shelf planning areas.

\begin{tabular}{lrrr}
\hline \multicolumn{1}{c}{ Planning area } & Sale & Year & $\begin{array}{c}\text { Bonus b'ds } \\
\text { (dollars) }\end{array}$ \\
\hline Beaufort Sea & BF $^{1}$ & 1979 & $488,691,138$ \\
& 71 & 1982 & $2,055,632,336$ \\
& 87 & 1984 & $866,86 C, 327$ \\
Chukchi Sea & 97 & 1988 & $115,261,636$ \\
Gulf of Alaska & 109 & 1988 & $478,032,631$ \\
& 126 & 1991 & $7,117,304$ \\
& 39 & 1976 & $559,836,587$ \\
Lower Cook Inlet & 55 & 1980 & $109,751,073$ \\
& RS-1 & 1981 & 176,496 \\
& 60 & 1977 & $398,471,313$ \\
Navarin Basin & RS-2 & 1982 & $4,405,899$ \\
North Aleutian Basin & 83 & 1984 & $516,317,331$ \\
Norton Basin & 92 & 1988 & $95,435,500$ \\
St. George Basin & 57 & 1983 & $317,873,372$ \\
\multicolumn{1}{c}{ Total } & 70 & 1983 & $426,45 \varepsilon, 830$ \\
& & & $6,440,315,773$ \\
\hline 1 Held jointly with the State of Alaska: sale revenues totaled \\
\$1,056,082,635.
\end{tabular}

employs 24 to 48 people (Anchorage Daily Nev's, January $7,1992)$. The Alyeska Pipeline workforce declined in the past year from 1725 to 1663 employees, and staffing levels are expected to continue falling by three percent to four percent per year through the 1990's.

Late in the year, Quality Technology completed its audit of Alyeska Pipeline. The report credits Alyeska employees with keeping the oil moving safely but criticized overall management of TAPS. Extensive manarement reforms and a doubling of the TAPS inspection force have been recommended (Oil and Gas Journal, 1993t).

\section{ACTIVITY BY FEDERAL AGENCIES}

\section{MINERALS MANAGEMENT SERVICE}

All publications listed in the following six sections on MMS activities and research are catalogued in appendix 1 under the MMS heading.

\section{LEASING AND EXPLORATION ACTIVITY}

Since 1976, the DOI has held 17 oil and gas lease sales on the Alaskan OCS (fig. 7, table 5), of ering over 546,330 square kilometers. The DOI has leased 34,400 square kilometers $(1,562$ leases) and has received $\$ 6.5$ billion in high bonus bids (table 6). A total of 1,216 leases have been relinquished or have expired, leaving 346 leases still held by oil and gas companies as of Derember 31, 1993. No lease sales for oil and gas were held on the Alaskan OCS in 1993. 


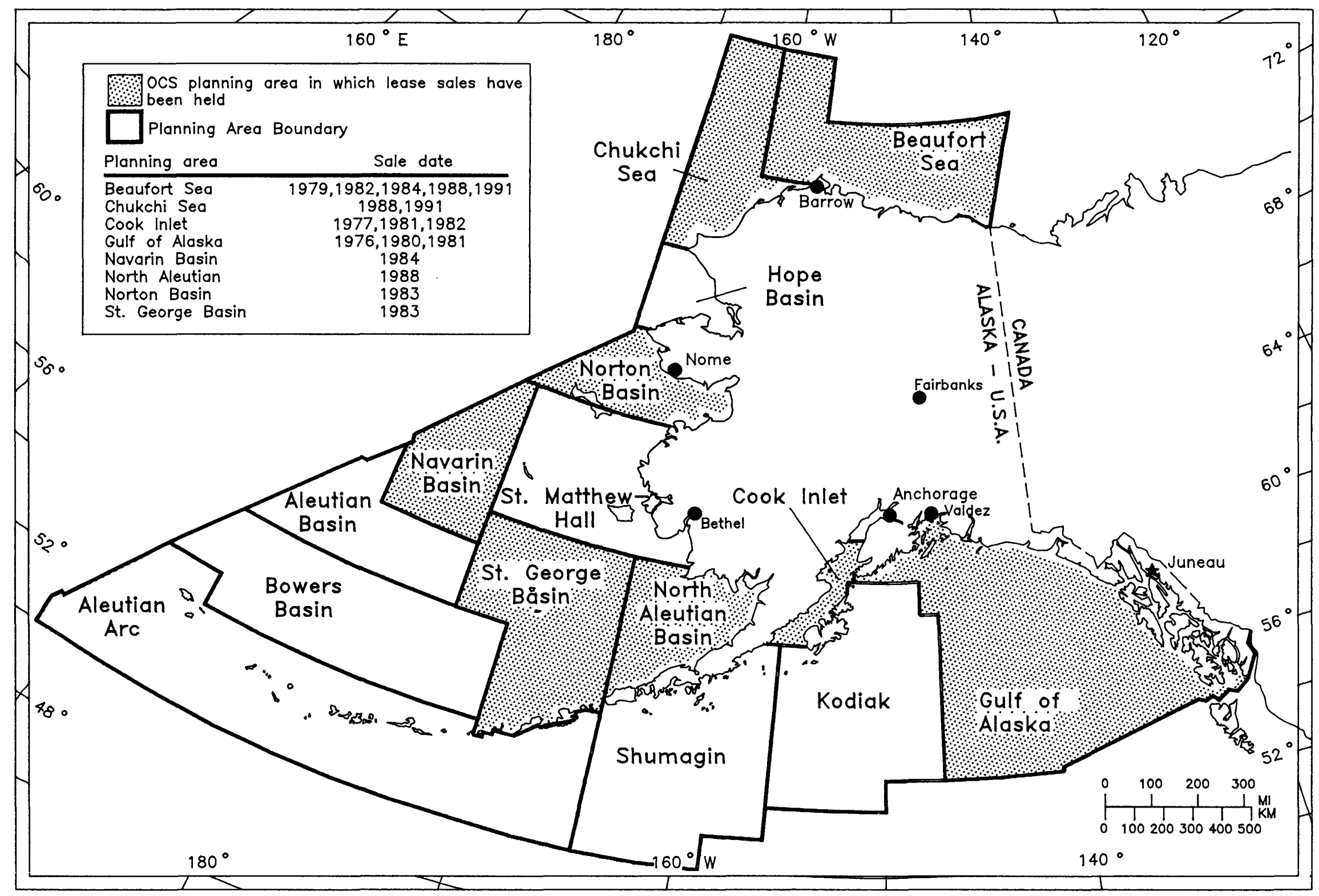

Figure 7. Alaska Outer Continental Shelf Region planning areas and lease sale history. 
Fourteen deep stratigraphic test (DST) wells and 82 exploratory wells have been drilled on the Alaskan OCS (table 5). In 1993, three exploratory wells were completed in the Beaufort Sea planning area, testing the Kuvlum and Wild Weasel prospects (fig. 6, table 4).

The majority of the exploratory wells drilled on the Alaskan OCS have been permanently plugged and abandoned. However, nine leases have been classified as "producible" (table 7), although none of them are considered economically productive under current economic conditions. As defined by MMS regulations at 30 CFR 250.11, a producible lease is one from which oil, gas, or both, can be produced in quantities sufficient to yield, after completion of the well, a return in excess of the cost of producing the hydrocarbons at the wellhead. All of these producible leases lie within the Beaufort Sea planning area; four of them have been relinquished. Other leases might also be producible, but that determination has not yet been made.

Beaufort Sea planning area.-Lease sales were held in the Beaufort Sea planning area in 1979, 1982, 1984, 1988, and 1991. A total of 631 tracts have been leased; 189 tracts remained active as of December 31, 1993. The status of an additional 20 blocks that received bids remains undetermined subject to questions of U.S.-Canadian jurisdiction. OCS Sale 144 is tentatively scheduled for the Beaufort Sea planning area in December 1996.

Twenty-nine exploratory wells have been drilled in Federal waters in the Beaufort Sea planning area. Three of the wells were completed in 1993: ARCO Alaska drilled the OCS-Y-0865 Kuvlum 2 and the OCS-Y-0866-2 Kuvlum 3 wells on the Kuvlum prospect north of the Arctic National Wildlife Refuge (Arctic NWR), and also drilled the OCS-Y-1597 Wild Weasel 1 well on a separate structure 11 kilometers south of the Kuvlum discovery well. The Kuvlum 1 well had been announced by ARCO in 1992 as a new oil discovery. In testing, the well flowed 3,400 $\mathrm{bbl} / \mathrm{d}$ with a gas:oil ratio of 17 cubic meters of natural gas per barrel. ARCO Alaska and its partners drilled two delineation wells during 1993 to determine the size and economic viability of the discovery. They had estimated that a billion barrels of recoverable oil would be needed for the field to be economic, because a 26-kilometer-long subsea pipeline and a 97-kilometer-long onshore pipeline would be required to transport the oil to the TAPS. ARCO announced in late 1993 that the Kuvlum prospect was not economically viable.

Chukchi Sea planning area.-Lease sales in the Chukchi Sea planning area were held in 1988 and 1991. A total of 378 leases were awarded in the two sales; 126 remained active as of December 31, 1993. A third lease sale, OCS Sale 148, is tentatively scheduled for June 1997.

Four exploratory wells were drilled in the Chukchi Sea planning area between 1989 and 1991. All have been permanently plugged and abandoned.
Table 7. Producible oil leases, Beaufo t Sea planning area.

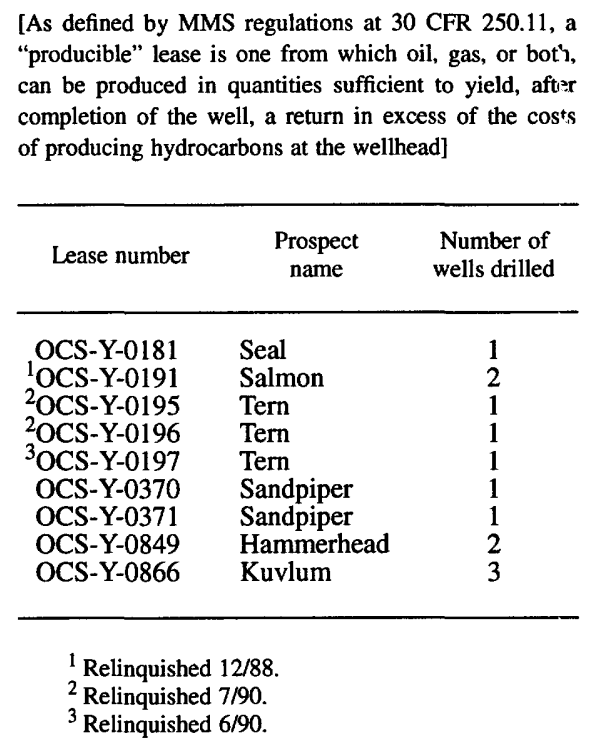

Cook Inlet planning area.-In the Cook Inlet planning area, 100 leases were awarded in two lease sales held in 1977 and 1981. In August 1982, a third leare sale reoffered blocks that had received no bids from the 1981 lease sale, but no leases were awarded. A fourth lease sale, OCS Sale 88, initially scheduled for December 1984, was postponed indefinitely by the Secretary of the Interior, citing the lack of industry interest in such a sale. At the time, poor exploration results had led to the relinquishment of many leases by the oil industry. There are currently no active leases remaining in the Cook Inlet planning area.

This scenario may change in the near future. In 1991, ARCO Alaska drilled the Sunfish well in Alaska State waters and discovered the first Cook Inlet oil found since 1965. ARCO estimated reserves as high as $750 \mathrm{mil}-$ lion barrels, which would make the field the fourth largest in Alaska. This discovery, plus improved seismic technology and new geologic interpretations of seismic data, have renewed industry interest in the Cook Inlet planning area. Extended-reach and horizontal drilling techno'ngy, platform modifications, and upgrades to production equipment have also been important in the revitalization of Cook Inlet's hydrocarbon exploration and development. The State held two successful sales in Cook Inlet in 199₹, and both the Federal and State governments have planned additional sales for the area. OCS Sale 149 in the Lower Cook Inlet area is scheduled for early 1996, and the State of Alaska plans an exempt sale to coincide with OCS Sale 149.

Thirteen exploratory wells and one DST well were drilled in the Lower Cook Inlet and Shelikof Strait between 1977 and 1985. All have been permanently plugged and abandoned. 
Gulf of Alaska planning area.-A total of 112 leases in the Gulf of Alaska planning area were awarded in three OCS sales held in 1976, 1980, and 1981; all of these leases have been relinquished or have expired. OCS Sale 114, a joint Gulf of Alaska/Lower Cook Inlet lease sale originally scheduled for March 1992, was postponed indefinitely in May 1989 to allow additional time to assess the effects of the Exxon Valdez oil spill. Sale 158 is being considered for the Gulf of Alaska/Yakutat area for mid-1996.

Twelve exploratory wells and one DST well were drilled in the Gulf of Alaska between 1975 and 1983. All of these wells have been permanently plugged and abandoned.

Kodiak Shelf planning area.-Six DST wells were drilled on the Kodiak Shelf in 1976 and 1977 to delineate the geologic framework and hydrocarbon potential of the area. Four lease sales have been tentatively scheduled for the Kodiak planning area since 1980 but have not been held due to low industry interest and to administrative postponements. No lease sales are presently scheduled for this area, although the MMS plans to conduct additional studies to gain a better understanding of the hydrocarbon resources of this area.

Navarin Basin planning area.-In the Navarin Basin planning area, 163 leases were awarded in OCS Sale 83 in April 1984. Seventeen additional blocks located within an area of disputed U.S.-Soviet jurisdiction also received bids, but the Secretary of the Interior subsequently concluded that it was not in the interest of the United States to retain the bids, and the bid deposits were refunded with interest in December 1988. Only two leases remain active, but they are due to expire in 1995; the remainder have been relinquished. A second lease sale, OCS Sale 107, was scheduled for 1991 but has been postponed indefinitely due to low interest by the oil industry.

Nine wells have been drilled in the Navarin Basin planning area: one DST well in 1983 and eight exploratory wells in 1985. All of these wells have been permanently plugged and abandoned.

North Aleutian Basin planning area.-OCS Sale 92 was initially scheduled in the North Aleutian Basin planning area in January 1986. However, a preliminary injunction prohibited opening of bids at that time, and completion of the sale was postponed until October 1988, when 23 leases were awarded to the high bidders. As a result of the Exxon Valdez oil spill in March 1989, these leases were placed under a 1-year moratorium and concurrent 1-year suspension of operations from October 1, 1989, to September 30,1990 , in order to allow time to study information gathered from the oil spill and to evaluate any environmental consequences of oil development on Bristol Bay fisheries. Four subsequent moratoria have resulted in suspension of operations in the North Aleutian Basin through September 30, 1994. Consequently, the lease owners have sued the Federal Government, alleging breach of contract and illegal seizure without due compensation. Pending resolution of this issue or completion of the moratoria and suspensions, lease expiration dates will be extended to the year 2004.

One DST well was completed in the North Aleutian Basin by ARCO Alaska in 1983. No exploratory wells have been drilled due to the moratoria.

Norton Basin planning area.-Fifty-nine leases were awarded in the Norton Basin planning area in 1983 in OCS Sale 57; all have been relinquished. Two additional lease sales, OCS Sales 100 and 120, were scl $: d u l e d$ for 1986 and 1992, respectively, but were canceled or indefinitely postponed due to low industry interest. Two DST wells were drilled by ARCO Alaska in Norton Basin prior to OCS Sale 57. Six exploratory wells were drilled in 1984 and 1985 on leases acquired by Exxon and ARCO Alaska; all of these wells have been permanently plugged and abandoned.

Saint George Basin planning area.-In the Saint George Basin planning area, 96 leases were awarded in OCS Sale 70, held in 1983. Six leases remained active in 1993 but are due to expire in 1994. Two other lease sales, OCS Sale 89 in 1986 and OCS Sale 101 in 1990, were canceled or postponed indefinitely due to low industry interest. For the same reason, OCS Sale 153, which had been considered for late 1996, will probably be delayed into the next 5-year (1997-2002) comprehensive program. As of June 1994, simultaneous lease sales are being considered by the United States and Russia for th 9 Chukchi Sea planning area and Russian areas to the west and southwest, to be held in June 1997. The Amsrican sale could also include part of the Hope Basin planning area.

Ten exploratory wells and two DST wells were drilled in the Saint George Basin prior to 1986; all have been permanently plugged and abandoned.

\section{FUTURE LEASE SALES}

The OCS Lands Act requires that the DOI prepare a 5-year program that specifies the size, location, and scheduling of areas to be assessed for Federal offshore natural gas and oil leasing. Accordingly, the MMS has prepared a comprehensive program for the management and leasing of natural gas and oil on the Alaskan OCS, 1992-1997 (Minerals Management Service, 1992). The proposal limits the amount of acreage offered for lease by excluding areas where resource potential and industry interest are low, thus reducing the uncertainty about potential effects of oil and gas development on other natural resources. Compared to previous 5-year programs, fewer sales will be considered in fewer areas.

Leasing will be considered in 4 of the 15 Alaskan OCS planning areas during the 1992-1997 program (fig. 8). One sale each will be considered for Lower Cook Inlet/Shelikof Strait (early 1996), the Gulf of Alaska/Yakutat Area (mid-1996), the Beaufort Sea (Decenher 1996), 


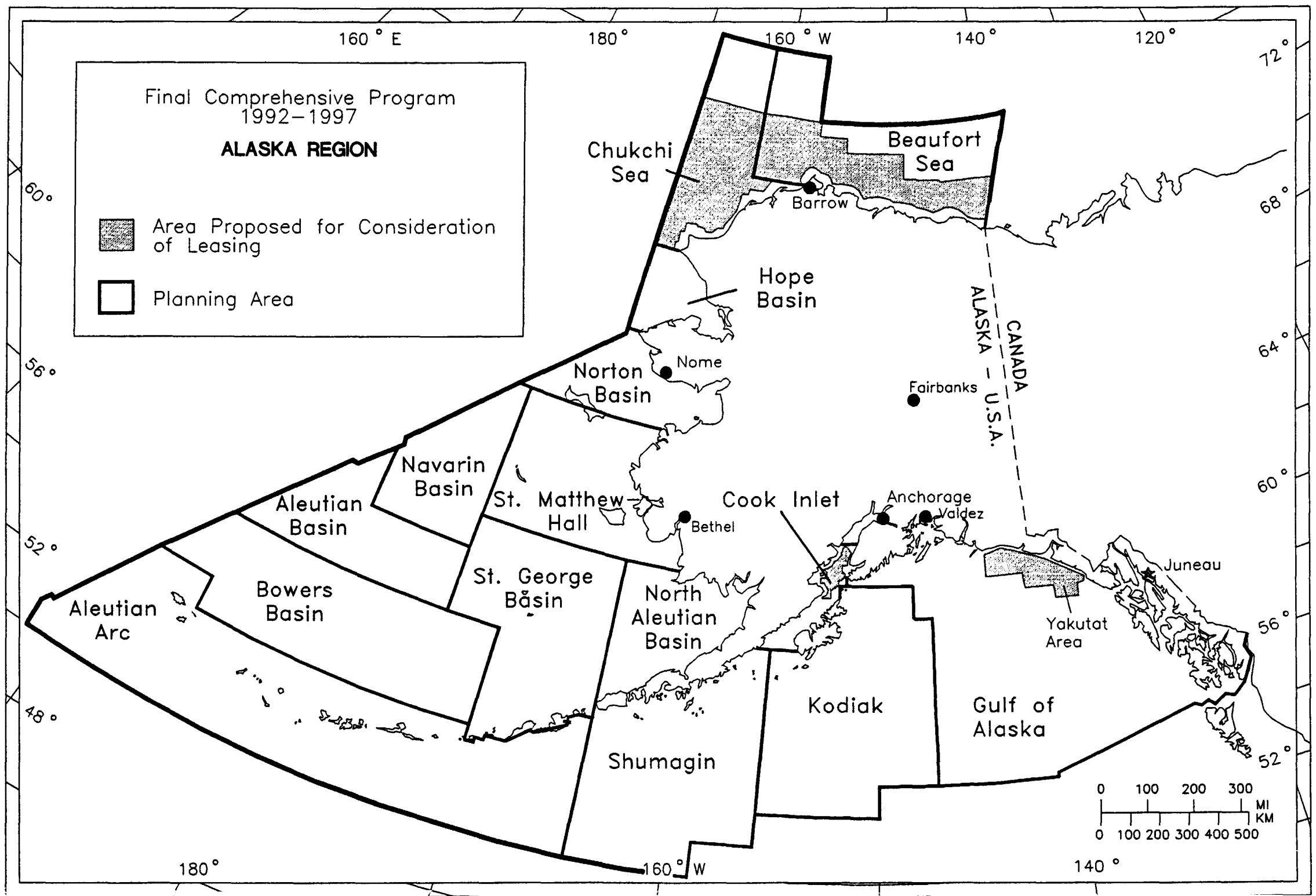

Figure 8. Areas proposed by the MMS for future lease sales or geologic and environmental studies, 1992-1997. Information current to January 1, 1994. 
and the Chukchi Sea (June 1997). Leasing in the Saint George Basin and the Hope Basin, which had been considered for the 1992-1997 program, will probably be delayed into the next 5-year (1997-2002) program.

No leasing will be considered for the remaining planning areas, but studies are planned for Gulf of Alaska (Middleton Island area), Kodiak, Navarin Basin, North Aleutian Basin, Norton Basin, Saint Matthew-Hall, and Shumagin. The studies are intended to focus on the hydrocarbon potential and environmental characteristics of these areas.

\section{OIL AND GAS RESOURCE ASSESSMENT}

The MMS prepares estimates of the undiscovered, economically recoverable oil and gas resources on the OCS as part of the Federal National Oil and Gas Resource Assessment. The results of the 1987 assessment were released in Mast and others (1989). In late 1989, the MMS initiated a review of OCS undiscovered resource estimates to determine if newly available geologic and geophysical information would warrant an update. Based on information available as of January 1990, new data for three Alaskan OCS planning areas significantly changed the 1987 estimates; the revised estimates were released in MMS OCS Report 91-0051 (Cooke, 1991). The next complete national assessment is scheduled for 1995 .

\section{DATA ACQUISITION ON THE ALASKAN OCS}

Geophysical exploration on the Alaskan OCS, which had reached a 28-year low in 1991, rebounded in 1992 when the oil industry acquired 2,832 line-kilometers of seismic-reflection data in the Lower Cook Inlet and on the Beaufort Shelf. In 1993, data acquisition continued in these two areas, totaling 3,150 line-kilometers of data in Federal waters; an additional 400 line-kilometers of data were acquired on the Gulf of Alaska OCS. Seismic activity focused on areas adjacent to or extending shoreward into State waters and, on the Beaufort Shelf, over the 1992 Kuvlum discovery. No permits for regional gravity or magnetic surveys were issued by the MMS for the Alaskan OCS in 1993.

Several factors have affected Alaskan OCS exploration activity: (1) the relatively high cost of exploration and production in the offshore Alaska environment is prohibitive under the present oil and gas economic conditions; (2) initial investigations in Alaskan OCS waters have reached a mature stage, especially with respect to understanding the geologic framework and petroleum potential of individual sedimentary basins; and (3) no economic hydrocarbon discoveries have been made on the Alaskan OCS. Although ARCO Alaska announced in late 1993 that its 1992 Kuvlum discovery, which initially looked very promising, was not economic, the discovery still has given impetus to further seismic exploration on the Beaufort Shelf.
JOINT FEDERAL-STATE STUDIES

In 1975, the MMS (then Conservatior Division, USGS) and the State of Alaska initiated joirt geologic studies along certain coastal areas of Alaska where geologic data were of mutual interest and where such data promised insights into the petroleum potential of adjacent onshore and offshore areas. Subsequent collaborations have investigated the Gulf of Alaska, Cook Inlet, Kodiak Islands (Kodiak Shelf), Seward Peninsula-Y Kuskokwim drainage (Norton Basin), Pribilof Islands (Saint George Basin), Alaska Peninsula (North Aleutian Basin), Waring Mountains (Hope/Selawik Basins), and the northeastern Brooks Range (Kaktovik Basin). Since 1984, the cooperative work has been funded by grants from the MMS-sponsored Studies Related to Continental Margins Program (SRCMP). Studies funded under SRCMP are administered by the Bureau of Economic Geology, University of Texas at Austin, and performed by the ADGGS.

In recent years, SRCMP studies have focused on the geology of the Arctic Slope and the Arctic NW? . Detailed geologic mapping and fission track studies of this area have provided insight into the thermal evolution of the Beaufort continental margin, particularly as it baars on the maturation history of key source rock sequences (O'Sullivan, 1988; O'Sullivan and others, 1989; Clough and others, 1990). Phase II of this regional study was initiated in 1991 and focuses on glauconite radiometric dating of the Lower Cretaceous unconformity surface and bounding strata in the Prudhoe Bay area, in the Arctic I'WR adjacent to the coastal plain, and westward along the northern foothills of the Brooks Range.

\section{ENVIRONMENTAL STUDIES PROGRAM}

The Alaska Environmental Studies Program (AESP) was created by the DOI in 1974 in response to the Federal Government's decision to lease areas of Alaska's OCS for oil and gas development. The purpose of the AESP is to determine information needs and implement studies to assist in predicting, assessing, and managing potential effects of oil and gas exploration and development on the human, marine, and coastal environments of Alaska and the Alaskan OCS. Although the program is administered by the MMS, additional assessment informatior is provided to the AESP by the National Oceanic and Atmospheric Administration (NOAA) and through direct cortracts with private enterprises.

The initial objective of the AESP was to cbtain baseline information on the physical characteristics and biological resources of the Alaskan environment. These studies included basic oceanography and meteorology, investigations of geologic and sea-ice phenomena, and biological surveys of marine species. As the OCS leasirg program was accelerated in the late 1970's and early 1980's, the 
emphasis of AESP studies shifted to the potential effects of oil contamination on biological resources and to the probable transport and dispersion of oil that might be spilled in the marine environment.

As the Alaskan OCS leasing program matures, and significant exploration activity declines, the mission of the AESP has been to conduct postlease studies to monitor the possible effects of oil and gas exploration and drilling activities on the OCS environment and its resources. AESP studies can be categorized into several broadly defined subjects: living resources, endangered species, environmental geology, ecosystems, pollutant transport, environmental monitoring, oil spill fate and effects, and social and economic studies. Descriptions of ongoing and proposed AESP studies in Alaska are presented in the Alaska Regional Studies Plan (Minerals Management Service, 1992).

\section{U.S. GEOLOGICAL SURVEY}

Research on the North Slope, gas hydrates, thermal history of Alaska, and the assessment of undiscovered oil and gas resources are the principal USGS activities directed at an improved understanding of onshore oil and gas resources in Alaska. These projects are funded by the Onshore Oil and Gas Investigations, the Climate Change, and the Alaska Mineral Resource Surveys programs. During 1993, USGS scientists conducted fieldwork on the North Slope, analyzed samples collected in the field, prepared several maps and reports, and held preliminary assessment meetings. Highlights from these projects were presented during 1993 at various technical meetings, including the American Association of Petroleum Geologists, the American Geophysical Union, the Rocky Mountain Association of Geologists, and the American Chemical Society. All papers listed in the following four sections on USGS oil and gas research are catalogued in appendix 1 under the USGS heading.

\section{NORTH SLOPE}

The major USGS energy study in Alaska is focused on the Arctic North Slope, an area with large amounts of Federal land and major oil and gas resources. Analysis of tectonic subsidence in the Colville foreland basin utilizes well and seismic data from the National Petroleum Reserve-Alaska (NPRA) and is designed to elucidate the response of the basin to the tectonic influence of the Brooks Range and the rift margin of the Canadian basin. A preliminary report on these studies was prepared in 1993 (Cole, Bird, and Howell, 1994). Burial histories of lithologies from wells in this area also provide data for thermal modeling of the North Slope.

During July, a month-long helicopter-supported field study was conducted in the south-central part of the
NPRA, mostly in the Killik River and Howarc Pass quadrangles. As the second of five planned traverses, this study was designed to improve evaluations of hydrocarbon potential in the Brooks Range foothills. Fieldwork focused on structural interpretations, methane sampling to test controls on gas occurrence, and rock sampling for thermal maturity, organic geochemistry, and sandstone (reservoir) petrography. A report describing some of the work accomplished along the first transect was published (Schenk and Bird, 1993).

During 1993, a collaborative reservoir stıdy was initiated with the ADGGS. This study in northwertern Alaska focuses on Early Cretaceous reservoir sandstones that are similar to the Kuparuk reservoir, from the Brooks Range to offshore areas. USGS work will concentrate on the subsurface realm using seismic and well data.

Preliminary findings of an ongoing study of the Sagavanirktok Formation, the youngest part of the foreland basin and the reservoir rock for the Kuvlum discovery, were presented (Fouch and others, 1993). A 10-day field investigation of Sagavanirktok outcrops is planned for 1994.

\section{GAS HYDRATES}

The North Slope Gas Hydrate Project has documented, by the use of well logs, the occurrence of natural gas hydrates in multiple sandstone reservoirs at shallow depth in the region overlying the Prudhoe Bay and Kuparuk River oil fields. The volume of natural gas in these hydrates is estimated at about 1.13 trillion cubic meters, an amount equivalent to the total volume of gas in all known conventional oil and gas fields on the North Slope. A major synthesis report on these findings was published (Collett, 1993a). Reports were also published, and talks presented, on production of gas from hydra ${ }^{+}$es (Collett, 1993b, 1993c), geochemistry of natural gas hydrates (Collett, 1993d), gas hydrates in permafrost (Collett and Bird, 1993a; Collett, Bird, and Magoon, 1993), gas hydrates as a source of atmospheric methane (Collett and Cunningham, 1993; Collett and Kvenvolden, 1993a; Kvenvolden and Collett, 1993; Kvenvolden, Collett, and Lorenson, 1993), a gas hydrate seismic reflector on the North Slope (Collett and Bird, 1993b), and the occurrence of hydrates in the MacKenzie Delta of Canada (Collett and Kvenvolden, 1993b). The North Slope Gas Hydrato Project is funded by the Onshore Oil and Gas Investigations Program, the Climate Change Program, and the DOE.

\section{OIL AND GAS RESOURCE ASSESSMENT}

As part of the current Federal National Oil and Gas Resource Assessment, considerable effort was devoted during 1993 to the assessment of undiscovered oil and gas resources in Alaska. Results of the national assessment are 
to be reported in early 1995 . During 1993 , numerous meetings and workshops were held to determine assessment procedures and methodology and to identify petroleum plays. A map showing the onshore Alaska provinces being assessed was published (Dolton and others, 1993). The economic aspects of the previous 1987 Alaskan assessment were also published (Attanasi, Bird, and Mast, 1993).

THERMAL MATURITY MAP OF ALASKA

USGS scientists completed a generalized thermal maturity map of Alaska in early 1992 (Johnsson and Howell, 1993). The completed map utilizes nearly 10,000 vitrinite reflectance and conodont color-alteration-index determinations from some 3,500 outcrop localities and 214 wells across Alaska to portray the thermal maturity of rocks exposed at the surface. For the North Slope and Cook Inlet regions, the map also shows the configuration of the top of the zone of oil generation. The map and data, in a Geographic Information System (GIS) format, will provide clues to the tectonic history and hydrocarbon potential throughout the State. A report describing some of the more salient features of the map was published (Johnsson, Howell, and Bird, 1993).

\section{BUREAU OF LAND MANAGEMENT}

The BLM has authority over all onshore Federal lands in Alaska for mineral leasing, economic evaluation of minerals, and inspection and enforcement of statutes governing minerals development. In addition, Federal statutes require that mineral potential information be included in the BLM's Resource Management Plans and that Federal lands be studied for the potential effect on Federal resources by activities occurring on adjacent, non-Federal leaseholdings. To support these activities, BLM geologists and geophysicists continually analyze data from Federal and State agencies to assess the mineral potential of BLM lands. BLM scientists often publish the resultant nonproprietary minerals studies as open-file reports. All papers listed in the following three sections on BLM research are catalogued in appendix 1 under the BLM heading.

\section{RESOURCE EVALUATION}

In 1993, BLM earth scientists and economists completed the minerals appraisals for two large land exchanges with Alaska Native corporations. These exchanges will allow the FWS to consolidate holdings and mineral rights within two wildlife refuges. In addition, the BLM Division of Minerals developed a Monte-Carlo-type mineral-resource estimate and economic evaluation model to use in future appraisals and bonus bidding situations. The model was developed using commercially available software and is currently being tested.

Several studies were initiated to better ilentify the oil and gas potential of NPRA. These studies in lude (1) a geologic analysis of reservoir potential of th: Nuiqsut Sands in northeastern NPRA, (2) the petrogra?hy of the Nuiqsut Sands in the Colville Delta area, and $(\hat{)})$ the geology of Breakup Sequence sandstones in western NPRA. This last study is in cooperation with the ADGGS as part of a larger study to identify new areas of oil and gas potential. These studies will be published as open-file reports in 1995.

Industry continues to express a moderate interest in an oil and gas lease sale in NPRA; however, due to low oil prices, all tract selection and tract evaluat'on studies related to such a sale have been suspended. These tract studies could be reinstituted following a rise ir oil prices or if there were favorable results from the aforementioned studies of the Nuiqsut Sands and Breakup Sequence sandstones. The BLM has received the seismic data shot during the winter of 1992-93 in northeastern NPRA, and industry has applied for another permit to gather data in the same area during the winter of 1993-94. Dise to limited funding, no oil and gas studies were initiated in 1993 in conjunction with BLM Resource Management F'ans.

Industry and public interest in the oil and gas potential of the Arctic NWR 1002 Area was greatly diminished in 1993. However, BLM geologists and geophyicicists continue to respond to inquiries as needed. To fulfill the requirements of Section 1002 of ANILCA, industr' continues to submit reprocessed data from the 1983-85 Arctic NWR exploration programs.

BLM geologists have been studying geologic information derived from the Aurora exploratory oil well in the Beaufort Sea, offshore from Arctic NWR. Two papers reporting research results were presented at the American Association of Petroleum Geologists Convention (Banet, 1993b; Mowatt and Banet, 1993), and a third paper was released as a BLM-Alaska Technical Report (Banet, 1993a). Other Aurora well studies completed in 1993 will be published in 1994 (Banet 1994d; Mowatt \& Banot, 1994a). Additional reports included papers on the petroliggy of outcrop samples in Arctic NWR (Mowatt and Banet, 1994b), the geochemistry of oils from the Chukchi Sea (Banet, 1994a, 1994c), and North Slope crude oil chemistry (Banet 1994b).

\section{LEASE OPERATIONS}

Royalty revenues from Alaska's onshore Federal oil and gas production ranked tenth in the United States.

The BLM's I\&E Program governs operations associated with the exploration, development, and production of oil and gas deposits from Federal leases in Cook Inlet. The I\&E strategy prioritizes the relative importance of 
various factors pertaining to leasehold operations, such as production volume, other resources, and operator compliance with health and safety, environmental, and legal requirements; the Automated Inspection Record System tracks field inspection data. The Sterling gas unit on the Kenai Peninsula will start producing in early 1994, and production of rental gas from the Swanson River field will also start in early 1994 . The BLM anticipates further development activities due to growing demand for natural gas in the Cook Inlet area.

The Branch of Lease Operations within the BLM's Division of Mineral Resources has developed a computer program that will retrieve data from the Petroleum Information Data Base, then export the information to other analytical and mapping software programs. This new data base retrieval program is available and applicable for similar uses by all BLM field offices. The Branch has also initiated use of a sophisticated well-log-analysis computer program to determine subsurface stratigraphy and structural geology for the purpose of assessing the hydrocarbon potential of various Federal lands offered for lease or exchange. In conjunction with the I\&E Program, the Branch has cooperated with the Alaska Department of Environmental Conservation (ADEC) in reviewing, assessing, and closing out various plugged and abandoned wells drilled on Federal lands throughout Alaska, including NPRA.

In establishing and implementing an oil and gas leasing program as required by Section 1008 of ANILCA, the BLM has made land available for noncompetitive oil and gas leasing in four areas south of latitude $68^{\circ} \mathrm{N}$. (fig. 9). Both the Minchumina and the Denali-Tiekel-Slana areas were opened in 1982, the Seward Peninsula in 1983, and the Iditarod-George area in 1990. As of September 30, 1993, the BLM had 749 nonproducing leases in these areas. The BLM also maintains 34 producing leases on the Kenai Peninsula. Except for the NPRA, all BLM-administered oil and gas estates in Alaska are now handled under the leasing system established by the Federal Onshore Oil and Gas Leasing Reform Act of 1987 and the Energy Policy Act of 1992. Drilling and production operations on BLM leases are administered through the BLM's Branch of Lease Operations.

\section{PIPELINE MONITORING}

The Branch of Pipeline Monitoring is part of the BLM's Division of Mineral Resources. The Branch's principal function is to ensure compliance with the terms and conditions of the Right-of-Way Grant issued to Alyeska Pipeline Service Company for the TAPS; Alyeska Pipeline is the operating company for TAPS. To fulfill this responsibility, the Branch works with the State/Federal Joint Pipeline Office (JPO) to develop and implement a coordinated monitoring program. The new requirements of the oil-spill contingency plan have been implemented, and a heightened awareness of oil-spill effects and remedies is evident throughout TAPS.

The Subcommittee on Oversight and Investigations, Committee on Energy and Commerce, U.S. House of Representatives, held a hearing on July 14, 1993, regarding Federal oversight of the TAPS and Alyeska Pipoline. As a result of the hearing, the BLM was directed to increase its oversight monitoring and auditing activity. The BLM responded by doubling its pipeline inspection force, and the JPO/BLM have contracted for consulting services concerning technical and procedural audits.

Work continues on wetlands mapping ard processing of the Federal Energy Regulatory Commission application for the Anderson Bay liquified-natural-gas facility near Valdez. Activities regarding the Trans- $A$ laska Gas System project were scaled back when the s'artup date was postponed. For a copy of the Annual Report of the Branch of Pipeline Monitoring, contact the BLM Public Affairs Office in the Federal Building in Anchrage (222 W. 7th Street, Box 13, Anchorage, AK 99513).

\section{NATIONAL PARK SERVICE}

The NPS provided comments to the State of Alaska and to the MMS on proposed oil and gas lease sales that were scheduled near National Park units, especially those sales in the Copper River basin and the Gulf of Alaska. Comments were specific to potential environmental impacts which might directly or indirectly affect park or wilderness values.

\section{U.S. FISH AND WILDLIFE SERVICE}

\section{KENAI NATIONAL WILDLIFE REFUGE}

The Kenai NWR is the only refuge in Alaska where commercial oil and gas production currently is permitted. Surface operations are regulated by the FWS, and subsurface activities by the BLM. Data for 1993 production from the refuge's Swanson River and Beaver Creel oil fields are included in table 2.

In 1992, refuge personnel and other FWS staff reviewed an environmental assessment prepared by ARCO Alaska for their proposed Stormy Lake East exploratory well and road south of the Swanson River field. In 1993, a right-of-way permit was issued to ARCO for the road and drill pad; however, development plans for the well have been deferred indefinitely.

At the Swanson River oil field, an aromatic hydrocarbon spill was discovered in the pipe and supply yard in 1990 . Initial efforts to remove the hydrocarbons with an air-stripping unit were successful, and site remediation is expected to continue until established cleanup levels are achieved. Unocal currently operates the Swanson River field. 


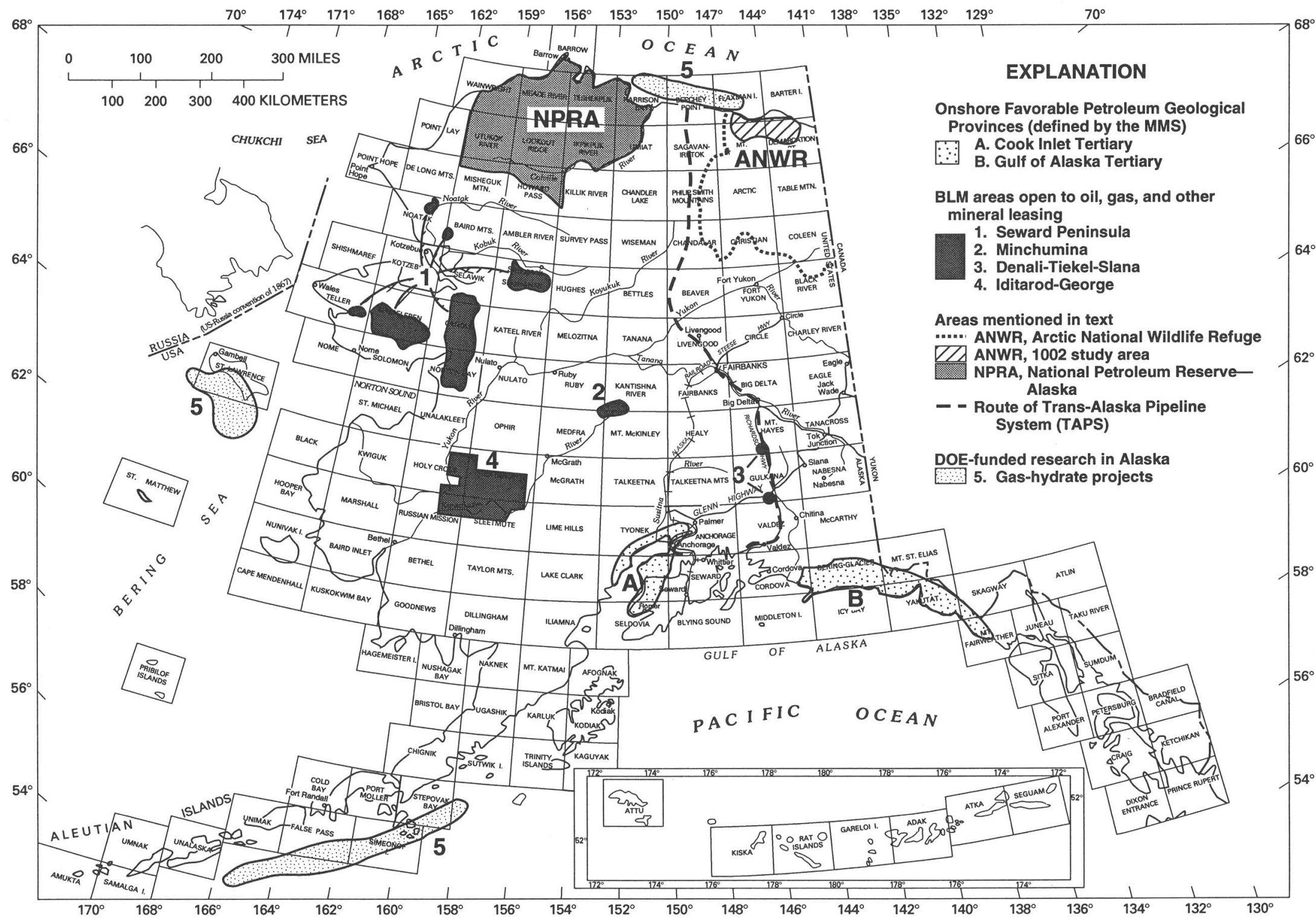

Figure 9. Onshore favorable petroleum provinces, land units referred to in text, and locations of DOE-funded research in 1993. 1:250,000-scale quadrangles are outlined and labeled. 
A diesel fuel spill was discovered in 1990 in the Beaver Creek field, which is operated by Marathon Oil; the company's remediation plan should be ready for agency review in early 1994. Marathon Oil also intends to drill a new well in the field in 1994.

In 1991, then-owner ARCO Alaska completed an environmental audit of chronic crude oil spills and leaks at tank settings and flare pits throughout the Swanson River field. A remediation pilot project was initiated in 1992 at one of the seven tank settings, and project results will be used to develop a comprehensive strategy in 1994. As the field's new operator, Unocal also plans to begin gas production in 1994.

In late 1993, the FWS issued a special-use permit to ARCO Alaska to test the effectiveness of various seismic techniques. Above-ground and hole-drilled charge tests were conducted in this segment of their seismic program.

\section{ARCTIC NATIONAL WILDLIFE REFUGE}

Section 1002 of the ANILCA sets out specific management constraints on a 6,070-square-kilometer strip within the coastal plain of the 78,914-square-kilometer Arctic NWR; this coastal strip is frequently referred to as the 1002 area (fig. 9). The FWS was designated as principal coordinator for a resource assessment required under Section 1002 and subsequently conducted a baseline study of the area's fish, wildlife, and habitats. The ANILCA also mandated a Report to Congress, which was prepared under the provisions of a 1983 interagency Memorandum of Understanding among the FWS, BLM, and USGS. The report (Clough and others, 1987) summarized the area's fish, wildlife, and hydrocarbon resources; described the development scenario and potential impacts of any future petroleum exploration and production; and outlined recommendations regarding possible oil and gas operations in the 1002 area, should they occur. However, the ANILCA prohibits oil and gas activities on the 1002 area unless authorized by an act of Congress, and the present Administration is opposed to opening the area to oil and gas exploration and development.

The FWS continues to pursue biological studies in the area. The goal of these studies is to achieve a better understanding of the area's natural dynamics, the altered ecosystem dynamics that might result from oil and gas activities, any associated adverse impacts, and the means to avoid, minimize, or rectify those adverse impacts. In 1992, the FWS completed and produced an interim report for the initial 5-year study program (McCabe and others, 1992). During 1993, studies relating to caribou productivity and habitat use, seismic impacts, snow goose staging habitat, musk oxen, polar bears, fisheries, weather data, and water resources were continued in order to address additional information objectives. Reports recently released on the 1002 area (see appendix 1, FWS section) include a vegetation map (Joria, 1992) and a study of grizzly bear preda- tion on musk oxen (McCabe and others, 1993). In 1993, the FWS also continued to respond to public and Congressional inquiries about the Arctic NWR coastal plain.

\section{ACTIVITIES UNDER SECTION 1008 OF ANILCA}

Section 1008 of the ANILCA provides for oil and gas studies on refuges in Alaska to gather information for use in future land-management decisions. In 1993, nine special-use permits were issued for minerals activities on the following national wildlife refuges (number of permits in parentheses): Alaska Peninsula/Becharof-surface geology (1), temporary transponder placement (1); Arcticsurface geology by government agencies (2), surface geology by universities (2), temporary navigation towers (1), helicopter VIP tours (1); Kanuti-surface geology by government agency (1). All special-use permits include specific stipulations to ensure that the permitted activities remain compatible with the purposes of the refuges and to protect refuge resources and refuge users. Commercial permittees must post bonds. Copies of all data gathered from refuge activities must be submitted to the FWS. After review by the FWS, the data are provided to the BLM for confidential storage.

\section{RESOURCE ACTIVITY IMPACT ASSESSMENT}

Permitting.-In 1993, the FWS commented on 19 individual Section 404 Clean Water Act Public Notices dealing with oil and gas activities off refuges. Activities covered by these Public Notices included oilfield activities at the Prudhoe Bay, Kuparuk, Endicott, Lisburne, Milne Point, and Point McIntyre fields, as well as the TAPS.

Lease sales.-The FWS reviewed and commented on Federal OCS Lease Sale 149 in Cook Inlet and on 11 proposed State oil and gas lease sales.

Monitoring.-The FWS conducts onshore and offshore environmental monitoring of contaminants introduced to fish and wildlife habitat from oil and gas activities. On the Kenai NWR, contaminant monitoring on six projects continued through 1993. The FWS also conducted water quality monitoring of migratory bird habitat in the Prudhoe Bay and Kuparuk oil fields.

Reclamation.--On the Arctic NWR, FWS personnel continued to monitor the progress of revegetation efforts at the Kaktovik Inupiat Corporation's exploratory well.

Regulation.-In December 1991, BP Exploration petitioned the FWS for promulgation of regulations that would allow the incidental, but not intentional, take of small numbers of (1) Pacific walrus and polar bears in the course of oil and gas exploration activities during the open-water season in State waters and on the Beaufort Sea OCS adjacent to the coast of Alaska, (2) polar bears in the course of oil and gas exploration activities in arctic Alaska 
(onshore and offshore) during the ice-covered period of the year, and (3) polar bears and walrus in the course of oil and gas development and production activities and associated vessel operations in arctic Alaska on a year-round basis. The FWS reviewed the petition and prepared a draft environmental assessment in conjunction with the proposed rule. The three-part petition was combined into one action that proposed regulations to authorize for 5 years the incidental and unintentional take of small numbers of polar bears and walrus during oil and gas exploration, development, and production activities year-round in the Beaufort Sea and adjacent northern coast of Alaska. The coast along the boundary of the Arctic NWR is excluded from the petition and regulations. The environmental review process led the FWS to conclude that the projected takings would have a negligible impact on the species populations and would not have an unmitigable adverse impact on the availability of such populations for subsistence uses. On December 30, 1992, the FWS published the proposed rule, notice of public meeting, and request for comments on BP Exploration's petition in the Federal Register.

The final ruling to authorize and govern the incidental, unintentional take of small numbers of polar bears and walrus during oil and gas industry operations (exploration, development, and production) year-round in the Beaufort Sea and adjacent northern coast of Alaska was issued on November 16, 1993. The regulation became effective on December 16, 1993, and will remain in effect until June 16, 1995. The final rule contains a provision that the FWS will develop and begin implementing a polar bear habitat protection strategy within 18 months of the effective date. This provision is in response to public comments on the proposed rule and is in agreement with the 1973 International Agreement on the Conservation of Polar Bears. If the Secretary of the Interior determines that the FWS has successfully developed and implemented the strategy, the regulation may be extended for a period not to exceed 5 years.

\section{DEPARTMENT OF ENERGY}

A primary petroleum target on Alaska's North Slope is the gas-hydrate reservoirs, which contain gas in a solid, icelike form. The DOE is investigating the technology for characterizing and developing this resource as part of its Natural Gas Technology Research subprogram. The study strives to delineate and define the geophysical and mechanical properties of hydrates and their reservoirs. Using both in-house and contractors' facilities, scientists conduct laboratory tests on natural and synthetic gas hydrates to characterize the pressure and temperature conditions necessary for their formation and dissociation. In addition, arctic research studies to determine in-place conditions of gas-hydrate deposits have been initiated by the DOE in cooperation with the USGS, ARCO Alaska, PP Exploration, Exxon, and Conoco (fig. 9). A study of the hydrate potential of the Walakpa gas field in northwestern Alaska has been published (Glenn and Allen, 1992).

\section{EXXON VALDEZ OIL SPILL}

The oil tanker T/V Exxon Valdez ran aground on Bligh Reef on March 24, 1989, spilling 41.6z million liters (262,000 barrels) of Prudhoe Bay crude oil into eastern Prince William Sound. Containment efforts failed, and oil from the tanker eventually impacted large areas of coastline in Prince William Sound, the Gulf of Alaska, the Kodiak Archipelago, and the Alaska Peninsula. Exxon spent over $\$ 2$ billion on cleanup operations in 3 years and was ordered in October 1991 to pay over $\$ 1$ billion in fines ( $\$ 25$ million), restitution ( $\$ 100$ million), and civil damages ( $\$ 900$ million) to the Federal and State governments. Exxon has paid the fine and restitution monies and will pay installments on the civil settlement until the year 2001.

Although most of the oil spilled is no longer obvious, toxic oil continues to be found in some environmentally important areas such as mussel beds. The long-term effects of the spill will continue to be a topic cf study and controversy. The U.S. Coast Guard (USCG), as the Federal on-scene coordinator, and the State of Alaska's on-scene coordinator officially announced on June $14,1 \div ? 2$, that the response phase of the Exxon Valdez oil spill cleanup was completed satisfactorily.

At the request of Exxon, the Alaska Maritime NWR issued a special-use permit to the oil company to allow sampling of the intertidal areas of Afognak Island in 1993. The intertidal zone was sampled for surface oi relating to the Exxon Valdez oil spill.

\section{ACTIVITY BY FEDERAL AGENCIES}

\section{MINERALS MANAGEMENT SERVICE}

While the MMS had no direct responsibility for oil spill response or damage assessment, the agency provided staff to assist the cleanup and monitoring efforts; an additional $\$ 300,000$ was directed to fund studies to assess the effects of the spill. MMS staff helped develop damage assessment programs, assisted in surveys and rehabilitation of seabirds and marine mammals, participated as members of a Resource Advisory Team, and provided technical expertise and assistance to the FWS and the Ala ka Department of Fish and Game (ADFG). Funding was provided for a study on the weathering of crude oil in seawater, for studies on the effects of oil on different species of fish and 
crustaceans, for surveys of sea otters and seabirds, and for collection of sediment samples for hydrocarbon analysis. In addition, support was provided for monitoring the performance of satellite-tracked surface oil drifters, for overflights of the spill, and for studies to determine the social impact of the spill on Native and non-Native communities adjacent to the spill's path. The MMS/NOAA research vessel \#1273 was provided for use as a field sampling platform. Funding from the MMS National Studies Program enabled the USGS to deploy the Gloria Project survey ship M/V Farnella in 1989 and the smaller USGSowned R/V Karluk in 1990 to collect bottom-sediment samples.

The Social and Economic Studies Unit (SESU) of the Environmental Studies Section of the Alaska MMS OCS Region is presently involved in collecting information on the long-term social, economic, and cultural consequences of the Exxon Valdez oil spill for a number of communities in the Gulf of Alaska region. The SESU modified an existing contract, the Social Indicators Study, to allow the collection of information during calendar years 1989 through 1991. In addition, the SESU signed a cooperative agreement in 1991 with the Subsistence Division of the ADFG to investigate the long-term subsistence and social consequences of the spill; this research is in progress.

\section{NATIONAL PARK SERVICE}

The Exxon Valdez oil spill impacted three National Park units: Kenai Fjords National Park, Katmai National Park and Preserve (NP\&P), and Aniakchak National Monument and Preserve. In these parks several hundred kilometers of shoreline and the resources and services supported thereon were affected by the oil and its cleanup. No cleanup operations have been undertaken on NPSmanaged lands over the past 2 years, but an oil-persistence survey conducted by the NPS in 1992 determined that small amounts of oil remained at more than 20 locations in these parks. In Katmai NP\&P, the oil still had the appearance of fresh mousse and produced a sheen when disturbed.

Damage assessment activities by the NPS ended in late 1991 after the settlement was reached in the criminal oil-spill litigation against Exxon. State and Federal trustees secured combined settlement revenues totaling more than $\$ 1$ billion. In accord with the settlement agreement, the focus of governmental spill-related activities in 1992 changed from damage assessment to restoration of injured resources. The NPS provided DOI representation to four groups: (1) the Restoration Team, (2) the Public Participation working group, (3) the Habitat Protection working group, and (4) the Restoration Planning work group. The NPS also chaired the DOI interagency working group that prepared a prospectus for a subsistence injury study. In 1993, the NPS served as Federal lead for the group that completed the draft Exxon Valdez Oil Spill Restoration Plan for the Trustee Council. Cooperative w'ork with NOAA on the oiled mussel restoration study was initiated in 1992 and continued in 1993.

Although the United States case against Exxon was settled, civil litigation by private plaintiffs is perding. The NPS continues to provide documents and records to litigants as a result of subpoenas filed in conjunction with these civil lawsuits.

\section{U.S. FISH AND WILDLIFE SERVICE}

During the fifth year following the Exxon Valdez oil spill, the FWS remained actively involved with natural resource damage assessment and restoration planning. Investigations by FWS personnel focused on migratory birds and sea otters, the trust resources most affected by the oil spill. Reports listed in appendix 1, FWS section, detail the results of studies on murres (Nysewander and others, 1993) and sea otters (Bodkin, Mulcahy, and Lensink, 1993; Garrott, Eberhardt, and Burn, 1993; Lipscomb and others, 1993). As in previous years, the FWS provided information on the location of bald eagle nests and seabird colonies to the USCG and the Alaska Departmert. of Natural Resources to protect them during beach inspections and clean-up operations.

The FWS participated in a restoration worl ing group that developed a plan to guide the future spending of settlement funds. The Restoration Plan was completed in November 1993 and approved by the Trustee Corncil. The plan provides a framework in the form of general policies that guide the types of projects that can be funded with restoration monies. The policies are: (1) target restoration activities to all injured resources and services, (2) pursue an ecosystem approach to restoration, (3) conduct restoration activities within the spill area, (4) emphasize restoration activities for resources and services that have not recovered, (5) administer projects that restore or enhance human use consistent with the character and public use of the area, (6) encourage competitive proposals for restoration projects, (7) submit projects to independen+ scientific review before approval, (8) actively solicit meaningful public participation in restoration decisions, and (9) only fund agencies for restoration work that they do not normally conduct.

The FWS also participated in an interagency habitat working group that developed a mechanism for evaluating and ranking large parcels of privately owned land within the oil spill area for protection. Eighty-one large parcels were evaluated and ranked. The working group also will develop a system for evaluating and ranking small parcels of privately owned land. 
Table 8. Mining production in Alaska, 1990-1993.

[Data from Bundtzen and others, 1994. Values calculated from 1993 price averages of gold, silver, platinum, zinc, and lead; other values directly supplied by mine operators. kg, kilograms; $\mathrm{g}$, grams; NR, no report; $\mathrm{W}$, information withheld by mine operators]

\begin{tabular}{|c|c|c|c|c|c|c|c|c|}
\hline & \multicolumn{4}{|c|}{ Volume } & \multicolumn{4}{|c|}{ Value $(\times \$ 1,000)$} \\
\hline & 1990 & 1991 & 1992 & 1993 & 1990 & 1991 & 1992 & 1993 \\
\hline Zinc (metric tons) & 164,350 & 252,346 & 248,978 & 243,774 & $\$ 253,680$ & $\$ 278,221$ & $\$ 301,958$ & $\$ 236,517$ \\
\hline Gold (kg) & 7,206 & 7,585 & 8,163 & 5,946 & 89,204 & 88,292 & 88,463 & 68,641 \\
\hline Silver $(\mathrm{kg})$ & 315,199 & 281,382 & 283,500 & 175,994 & 50,675 & 39,114 & 34,913 & 24,333 \\
\hline Lead (metric tons) & 40,106 & 63,119 & 62,278 & 34,667 & 30,954 & 33,404 & 31,585 & 13,759 \\
\hline Tin $(\mathrm{kg})$ & 25,855 & 3,084 & 680 & 9,526 & 200 & 22 & 6 & 51 \\
\hline Platinum (g) & NR & 465 & $\mathrm{~W}$ & 95 & NR & 5 & W & 1 \\
\hline $\begin{array}{l}\text { Sand and gravel } \\
\text { (million metric tons) }\end{array}$ & 13.6 & 12.8 & 13.2 & 12.3 & 40,822 & 45,449 & 42,200 & 39,650 \\
\hline $\begin{array}{l}\text { Building stone } \\
\text { (million metric tons) }\end{array}$ & 2.9 & 2.7 & 2.6 & 3.1 & 22,100 & 22,500 & 22,971 & 24,695 \\
\hline $\begin{array}{l}\text { Jade and soapstone } \\
\text { (metric tons) }\end{array}$ & W & 14.5 & 1.4 & 2.4 & W & 12 & 30 & 20 \\
\hline Coal (metric tons) & $1,429,000$ & $1,396,780$ & $1,389,340$ & $1,439,223$ & 44,990 & 39,000 & 38,300 & 38,104 \\
\hline Peat (cubic meters) & 49,699 & 57,345 & 53,552 & 55,051 & 400 & 450 & 400 & 445 \\
\hline TOTALS $\ldots$ & $\ldots$ & $\ldots \ldots \ldots$ & $\ldots$ & - & $\$ 533,025$ & $\$ 546,469$ & $\$ 560,826$ & $\$ 446,216$ \\
\hline
\end{tabular}

\section{COAL AND PEAT RESOURCES}

\section{OVERVIEW OF INDUSTRY ACTIVITY}

Alaska's 1993 coal production, valued at $\$ 38.1$ million, rose 3.6 percent over 1992 levels to 1.44 million metric tons (table 8). This contrasts with a 4.1-percent decrease in total estimated domestic output to 868 million metric tons (Coal News, January 17, 1994). All commercial Alaskan coal was produced at the Usibelli Mine near Healy, the only active coal mine in the State (fig. 10). Approximately one-half of the coal is used for in-State power generation, and the other half is exported to South Korea from a coal terminal in Seward. Undeveloped coal resources include the Aluaq Mine in the western Brooks Range, Beluga near Cook Inlet, and Wishbone Hill in the Matanuska Valley.

Abundant coal resources exist on the western North Slope of Alaska (Stricker, 1991), and the Arctic Slope Regional Corporation is actively pursuing the development of coal as an alternative to fuel oil. Their proposed Aluaq Mine, located 145 kilometers north of the Red Dog zinc mine, has received from the Alaska Department of Natural Resources a surface-mining permit to mine 45,360 metric tons of coal over a 5-year period (Callahan, Denton, and Imm, 1993). The three principal coal seams at the mine reach a maximum combined thickness of 11.6 meters, and coal from the thickest bed has an average heat value of 7,270 kilocalories per kilogram, moisture content of 3.26 percent, and total sulfur content of 0.23 percent. Burning this coal produces sulfur dioxide emissions that are less than one-quarter of the standard limits set by the U.S. Environmental Protection Agency (EPA). By establishing a domestic market for Aluaq coal, the Arctic Slope Regional
Corporation hopes to accelerate development of the mine in order to attract international markets.

The Alaska Department of Environmental Conservation issued a State air-quality permit for the Healy Clean Coal Project in early 1993 (Anchorage Daily News, March 11, 1993); this was one of the last permits that the Golden Valley Electric Association (GVEA) of Fairbanks needed to begin construction of its proposed 50-megawatt power plant. The new facility will be built next to GVEA's existing 25-megawatt plant, adjacent to the Usibelli coal mine and 16 kilometers northeast of the entrance to Denali NP\&P. Trustees for Alaska, an environmental law firm, protested the permit, predicting a deterioration of air quality in the park from plant emissions (Anchorage Daily News, April 17, 1993). The GVEA agreed to reduce emissions at its present plant so that combined emissions from the two plants working together would not exceed present levels (Fairbanks Daily News-Miner, November 10, 1993). Trustees for Alaska has also appealed the State Superior Court ruling in November 1993 that upheld the project's operating license from the Alaska Public Utilities Commission (Anchorage Daily News, December 17, 1993). The Healy Clean Coal Project is part of a national program to demonstrate methods of burning coal without emitting pollutants such as sulfur dioxide and nitrogen oxides, the major contributors to acid rain. The subbituminous coals mined at Healy already have some of the lowest reported sulfur values for any coal being mined in the United States (Stricker, 1991).

The Alaska Industrial Development and Export Authority (AIDEA) approved a \$6.9-million investment in Suneel Alaska's Seward coal terminal, allowing the exporter to refinance debts incurred by terminal construction (Anchorage Daily News, November 12, 1993); the money 


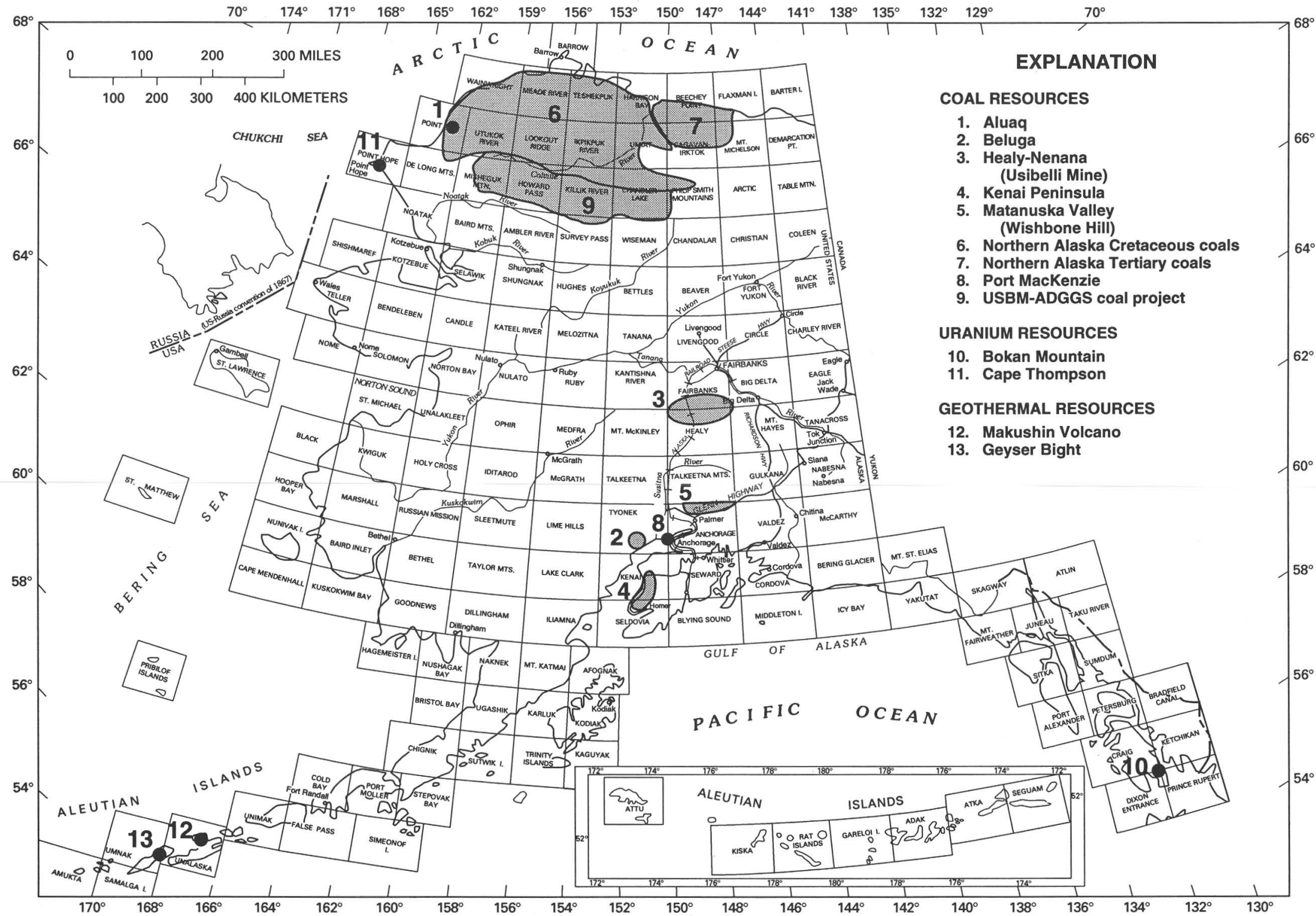

Figure 10. Areas of potential coal, uranium, and geothermal resources mentioned in text. 1:250,000-scale quadrangles are outlined and labeled. 
is to be repaid by the company over a period of 10 years. In addition, Anchorage is exploring the potential for developing a coal-exporting facility: an agreement was signed for a 1-year lease option on 0.4 square kilometers of tidelands near the existing Port of Anchorage (Alaska Journal of Commerce, February 8, 1993). A coal terminal at Anchorage would significantly lower transportation costs for central Alaska's coal.

An innovative technology that creates a coal-slurry fuel will be tested in Alaska. In a process developed at the DOE Energy and Environmental Research Center in North Dakota, low-rank coal/water fuel can be produced by high-temperature and high-pressure cooking of subbituminous coals; the resultant product can be burned in industrial boilers in place of heavy oil. Low-rank coal/water fuel is low in sulfur, easy to transport, and cheaper to produce than fuel oil. The Alaska Science and Technology Foundation has asked the AIDEA to oversee a pilot project to test the economic feasibility of the process (Alaska Journal of Commerce, December 13, 1993).

By year's end, status of the Alaska Mental Health Lands litigation still had not been resolved. The U.S. Congress created the 4,047-square-kilometer land trust in 1956 to provide funding for mental health programs; significant coal deposits in interior and south-central Alaska were included in this trust. The State legislature dissolved the trust in 1978, but mental-health advocates sued to reconstitute the trust in 1982. Consequently, all State land conveyances, permits, and leases on trust lands have been in abeyance since 1990. Legislation introduced in 1993 was not considered before the end of session, but a court ruling may occur by mid-1994 (Alaska Journal of Commerce, November 29, 1993). Two coal projects affected by the land entanglement are Wishbone Hill, which was to have begun production in 1992, and Beluga. Development work at these sites was being maintained in anticipation of the case's settlement.

Peat mined in Alaska is used primarily in agriculture and greenhouses as a soil conditioner; minor amounts are burned locally in villages for heat. Peat production increased in 1993 to 55,051 cubic meters, up 2.8 percent from 1992 (Bundtzen and others, 1994). Alaska has one of the world's largest peat resources, estimated to be five times the energy potential of Prudhoe Bay.

\section{ACTIVITY BY FEDERAL AGENCIES}

\section{U.S. GEOLOGICAL SURVEY}

Branch of Coal Geology personnel investigated the coal-bearing Tyonek and Beluga Formations of the Kenai Group during the summer of 1993 . They measured $63 \mathrm{sec}-$ tions between Homer and Anchor Point along the eastern shore of the Cook Inlet (fig. 10). They also measured 10 sections of the Tyonek Formation along the Chuitna River at the southern end of the proposed Diamond Chuitna Coal project, located 72 kilometers west of Anchorage. Papers published as a result of this work are listed in appendix 1, USGS section (Flores and Stricker, 1994a, 1994b; Flores, Stricker, and Roberts, 1994).

\section{U.S. BUREAU OF MINES}

The USBM contracted the ADGGS to digitize and calculate the coal resources of the Colville Mining District and southwestern NPRA (fig. 10). This work was done with assistance from the USGS as part of the USBM's Colville Mining District study. The results of the evaluation will be published in 1994 .

\section{NATIONAL PARK SERVICE}

The AIDEA has proposed building a 50-megawatt coal-fired power plant, the Healy Clean Coal F-oject, less than 6.5 kilometers from the eastern boundary of Denali NP\&P. Denali is the only national park in Alaska that has been designated as a Class I area under the Cle^n Air Act, and the DOI has an affirmative responsibility to protect the air-quality-related values of Class I areas. Due to potential adverse impacts to Denali NP\&P, the DOI recommended that the State deny the project's air quality permit, but the State issued the permit on March 10, 1993. The DOI and Trustees for Alaska requested a State adjudicatory hearing to re-evaluate the permit and engaged in intensive discussions with the DOE and other project proponents. These discussions culminated in a mitigation agreement that was signed in November 1993, and the DOI withdrew from the adjudicatory proceeding. The agreement requires retrofit of the existing Healy power plant with new emissions-control technology, strict emission limitations for both power plants, and a provision to renegotiate the agreement if plumes or haze from either power plant impairs visibility inside Denali NP\&P. The project was evaluated under the National Environmental Policy Act.

Subsequent to the reporting period of this document, a Record of Decision was signed in March 1994 by the DOE approving $\$ 110$ million in Federal fund ng for the construction and operation of the clean coal technologies to be demonstrated by the Healy Project. The Trustees for Alaska settled their grievance in June 1994 in an agreement that calls for air-quality monitoring, control of fugitive road dust, extended camera-based visibility monitoring, and a program to both reduce electrical demand and study alternative energy systems.

\section{DEPARTMENT OF ENERGY}

Plans for the new and innovative 50-megawatt coalfired power plant at Healy have moved into the final design 
and engineering phase. Using advanced combustion and flue-gas-cleanup technologies, the plant is intended to demonstrate the combined removal from stack emissions of particulate matter and the nitrogen-oxide compounds and sulfur dioxide that contribute to acid rain. Proposed construction is sited adjacent to the existing GVEA's Healy Unit 1.

The Alaska Public Utilities Commission gave its approval to the Healy Clean Coal Project on September 3, 1992, and recommended that the AIDEA be granted the "certificate of public convenience and necessity" needed for the project to move forward. The commission also approved a power sales agreement between the AIDEA and the GVEA, the new plant's operator and primary customer. A final Environmental Impact Statement (EIS) was prepared for the project by the DOE in December 1993 (Pittsburgh Energy Technology Center, 1993).

The new plant is being financed by a $\$ 110$-million Clean Coal Technology cooperative agreement monitored by the DOE's Pittsburgh Energy Technology Center; the agreement was awarded on April 11, 1991. A consortium headed by the AIDEA will provide the remaining $\$ 117$ million for the project's completion. The DOE funding for this project is part of a national program to demonstrate the new and clean methods of burning coal while limiting the emission of pollutants commonly cited as the causes of acid rain.

\section{URANIUM RESOURCES}

\section{OVERVIEW OF INDUSTRY}

The U.S. uranium mining industry continues to decline. The last conventional open-pit uranium mine closed in March 1992 (Odell, 1993). A few in-situ leach plants and by-product plants remain in operation, but domestic production was only 1.35 million kilograms of uranium. The conversion of highly enriched weapons uranium to nuclear fuel in both the United States and the Commonwealth of Independent States could require up to 40 years for depletion of stockpiles (Pool, 1994). Domestic nuclear power plants currently use about 16.5 million kilograms of uranium annually to produce 21 percent of the Nation's electrical energy (Chenowith, 1993; Pool, 1991). The uranium used for energy production comes mostly from stockpiles and imports.

The Secretary of Energy declared the domestic uranium industry to be nonviable for the ninth straight year. The surplus of uranium on world markets has pushed its unrestricted spot price to a near-record low of $\$ 13.09$ per kilogram, more than $\$ 5.00$ per kilogram less than domestic prices. The U.S. Department of Commerce has restricted certain imports of uranium until domestic prices rise (Chenowith, written commun., 1993).

No money was spent on uranium exploration in Alaska in 1993.

\section{ACTIVITY BY FEDERAL AGENCIES}

\section{U.S. GEOLOGICAL SURVEY}

The uranium/radon research program in the USGS was significantly reduced in 1993 and will end on September 30,1994 . A new energy program will emphasize the environmental aspects of energy minerals and may fund continued research on natural and man made radionuclide dispersement in the environment.

\section{U.S. FISH AND WILDLIFE SERVICE}

An environmental assessment was written by the Alaska Maritime NWR for the remediation of radiation contamination at the Project Chariot site (fig. 10) near Cape Thompson (Alaska Maritime National Wildlife Refuge, 1993). International Technology Corporation (ITC), a DOE contractor, carried out the remediation project. In June and July of 1993, a site reconnaissance, aerial photographic survey, and aerial gamma survey were completed. In August, the project focused on removal of th $\%$ disposal mound, a radiological survey of the test plot areas, and the sampling and analysis of surface waters and sediments in Ogotoruk and Snowbank Creeks. Background and biota sampling of nearby Kisimilok Valley was also accomplished. Due to specified weight limitations for all equipment on the tundra, ITC utilized special mats and uni-mats for mobilizing their heavy equipment to the removal sites. All soil removed was placed in 61 containers, sealed, barged to Seattle, and trucked to the Nevada Te ${ }^{\text {st Site for }}$ final placement. Biota analyses were performed at the ITCSt. Louis laboratory and were completed by mid-December. The total on-site assessment and remediation work lasted 38 days. The ADEC, FWS, Foster-Wheel 9 r Enviresponse (contractor for the Native people), and local representatives were all present for project oversight.

Of the original 26 millicuries of radioactive isotopes taken to the site in 1962, iodine and strontium were no longer detectable at concentrations greater than background levels. However, cesium was found at levels exceeding 50 millicuries per gram in some areas. The disposal mound had the expected amount of 3 millicuries per gram of cesium-137, and one cesium plot was found that ccntinued to emit radiation greater than background levels. Plant and animal samples showed no indication of man mate sources of radioactivity from the 1962 tracer study, but there were indications of man made radioactivity present from worldwide fallout.

The ADEC approved closure of the site in late August 1993. Disturbed areas were revegetated with Alaskan seed. A site inspection will occur in 1994 to determine the success of the revegetation effort; if needed, the area will be reseeded. Public meetings will be held in Foint Hope and Kivalina to present the final results of the sampling. 


\section{GEOTHERMAL RESOURCES}

Hot springs occur throughout Alaska and historically have been used locally for recreation, space heating, and agriculture. Widespread active volcanism in the Aleutian Islands, the Alaska Peninsula, and the Wrangell Mountains has created the potential for commercial geothermal energy production to serve selected population centers. The identification of Makushin Volcano and adjacent area (fig. 10) remains under review by the AIDEA as a potential source of power for the neighboring communities of Dutch Harbor and Unalaska, centers of the fishing industry in the northwestern Pacific Ocean. The ADGGS has estimated that the geothermal resource of the Geyser Bight geothermal area on Umnak Island could provide 246 megawatts of electrical power over a period of 30 years (Motyka and others, 1993).

No Federal research was funded for geothermal studies in Alaska in 1993.

\section{NONFUEL-MINERAL RESOURCES}

\section{METALLIC MINERALS}

The locations of mineral deposits, mines, and areas discussed in the following review of 1993 industry activity are shown on figure 11 .

\section{ECONOMIC OVERVIEW}

The total value of Alaska's mineral industry, measured by the value of mineral production plus exploration and development expenditures, dropped significantly in 1993 when metallic-mineral production dropped to $\$ 343$ million, a 25-percent decrease from 1992 values (table 8). Factors causing this decline include depressed base-metal prices, closure of the Greens Creek silver-lead-zinc mine, and reduced production at the Valdez Creek gold placer. Exploration and mineral development also experienced minor declines in spending, dipping 6 percent to $\$ 28$ million, and 8 percent to $\$ 27$ million, respectively.

Although zinc remains the most valuable ore commodity in Alaska, and 1993 production was only 2 percent below 1992 output, depressed base-metal prices dropped the value of mined zinc to $\$ 236$ million, 22 percent below 1992 levels. The Red Dog Mine in northwestern Alaska is the largest zinc producer in North America, producing 64 percent of domestic zinc (Bundtzen and others, 1994). Lead production and prices suffered a fate similar to zinc's, dropping 44 percent in amount and 56 percent in value. Gold continues its second-place role in ore commodity value, comprising 20 percent of metallic-mineral produc- tion. Improved precious-metal prices slightly mitigated the decreased production of gold and silver. Tin proved to be the year's surprise commodity: as a by-prodict of gold placer operations in Tofty and Ruby, Alaska's modest tin production increased 14-fold over 1992 output. Primary tin mining in Alaska ceased when Lost River Miring's Cape Creek placer mine on the Seward Peninsula clos?d in 1989.

The number of active mining claims in A laska continues to drop. Preliminary estimates for 1993 show 20,705 Federal mining claims and 27,469 St`te mining claims, down from 20,933 Federal claims and 2?,116 State claims in 1992. The new $\$ 100$-per-claim rental fee for mining claims on Federal lands went into effert in 1993. Claims are considered abandoned if the rental fees are not paid.

The settlement of Alaska State and Native land claims is changing the context of minerals exploration in Alaska. Much of the non-Federal land in Alask minerals exploration. The State of Alaska reopsned 2,250 square kilometers of its lands to mineral entry in November 1993 , bringing to 388,500 square kilometers the amount of State land open to mining (Northern Miner, Dicember 6, 1993). In addition, the Alaska Regional Native c orporations own more than 178,000 square kilometers of lend and are actively seeking joint ventures with mining companies.

\section{PRECIOUS METALS}

Tricon Mining, the operating subsidiary of Silverado Mines, is investigating buried placer gravels at Nolan Creek in northern Alaska's Koyokuk Mining District. Drilling there has revealed a gold-bearing alluvial channel, known as the Thompson Pup paystreak; reserves have been estimated by Tricon at 465,000 to 620,000 grams of gold (Mining Journal, February 12, 1993). Drift mining began in late 1993.

FreeGold Recovery and AMAX Gold signed an option/joint venture agreement for development of FreeGold's Golden Summit project, 32 kilometers north of Fairbanks (Mining Journal, April 30, 1993). Al MAX spent $\$ 500,000$ in 1993 for drilling, geochemical sampling, mapping, and airborne geophysical surveys, then returned the property to FreeGold in early 1994.

Fairbanks Gold Mining, the operating suhsidiary of AMAX Gold, spent $\$ 8$ million in 1993 to develop the Fort Knox gold-silver property (Bundtzen, written commun.), located 24 kilometers northeast of Fairbanks in the Fish Creek drainage. The projected open-pit mine will operate on a year-round basis and is expected to produc 9 million grams of gold annually from the prophyry-tyse deposit; total reserves contain an estimated 128 million grams of gold (Bundtzen and others, 1994). Gold recovery will utilize conventional extractive technologies to treat 32,000 to 45,000 metric tons of ore per day. The project has an estimated capital cost of $\$ 220$ million to $\$ 240$ million and 


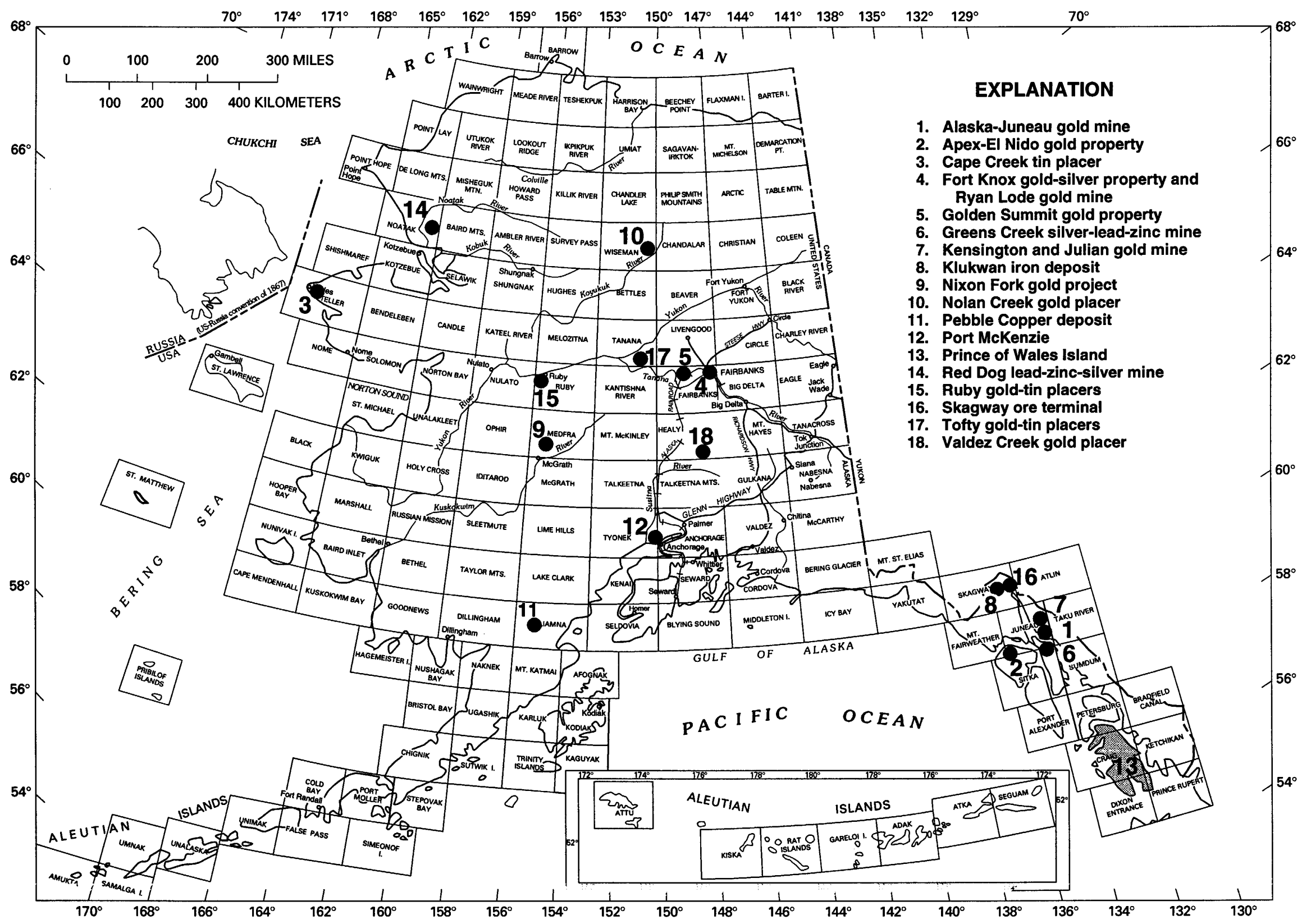

Figure 11. Areas of significant industry activity involving metallic minerals (excluding uranium) in 1993, and mine and deposit locations referred to in text. 1:250,000-scale quadrangles are outlined and labeled. 
plans to employ 250 workers. The company is currently working to obtain the necessary permits; subsequent construction will require 18 to 24 months.

La Teko Resources announced certified, mineable reserves of over 10.3 million metric tons of ore containing 25.5 million grams of gold at its Ryan Lode Mine on Ester Dome near Fairbanks, (Mining Journal, July 23, 1993; Bundtzen and others, 1994). Exploration programs in 1993 included drilling, geologic sampling, and geochemical soil surveys. A total of 4,000 meters was drilled in 37 holes; 21 holes had intercepts averaging 20.7 meters of true vein thickness, grading 3.2 grams of gold per metric ton.

In west-central Alaska, Consolidated Nevada Goldfields, the U.S. subsidiary of Australian-based Gwalia Consolidated, acquired the Nixon Fork gold project from the Nixon Fork Joint Venture for \$7 million (Mining Journal, September 3, 1993). The new owners conducted drilling, trenching, and environmental studies in 1993. Proven and probable reserves are estimated at 85,000 metric tons of ore grading 48 grams of gold per metric ton; underground mining methods could produce up to 1.87 million grams of gold annually (Bundtzen and others, 1994). The company expects to find more reserves during mine development.

The Kensington gold project, a joint venture between Echo Bay Alaska and Couer Alaska, is located about 64 kilometers north of Juneau on Lynn Canal. The Record of Decision for the final EIS on the project was issued in January 1992, and various administrative appeals filed in opposition to the Decision have been decided in favor of the project proponent. In November 1992, the Juneau Planning Commission voted to issue a large-mine permit for the project, and an appeal filed in opposition to this permit was rejected by a unanimous vote of the Juneau Assembly in February 1993. Following this action, a lawsuit was filed in State Superior Court to block the permit's approval. In March 1994, the Court found in favor of the proponent and the City and Borough of Juneau. The mine's reserves are calculated at 10.4 million metric tons grading 4.9 grams of gold per metric ton; annual production would yield 6.2 million grams of gold (Wells, 1992). As of December 1992, about $\$ 80$ million had been spent on the Kensington project (Northern Miner, May 31, 1993).

Coeur Alaska obtained controlling interest in the Jualin Mine, located near the Kensington project. The mine has been dormant since 1917 but is estimated to have more than 12.4 million grams of gold reserves (Anchorage Daily News, July 22, 1993).

Echo Bay Alaska started a new phase of exploration at its Alaska-Juneau (A-J) gold mine in the State's capital city. The $\$ 15$-million program of drilling and tunneling is scheduled to last 18 months and is expected to increase the mine's known reserves by 20 to 30 percent (Northern Miner, May 31, 1993). The mine previously had proven, probable, and inferred reserves of 91 million metric tons of ore containing 162 million grams of gold. The company anticipates that 20,400 metric tons of ore will be mined daily (Alaska Journal of Commerce, May 31, 1993) and expects to employ 450 people to operate the mine during its minimum estimated lifespan of 13 years (Anchorage Daily News, May 2, 1993). Echo Bay has proposed to begin mine construction in the summer of 1994 and production in 1997; the company has already spent $\$ 54$ million on mine development.

In May 1993, the Juneau Planning Commission authorized a large-mine permit for the A-J Mine. Project opponents appealed the Commission's decision to the Juneau Assembly, which dismissed the appeal on September 22, 1993. Echo Bay Alaska must still obtain 21 State and Federal permits in order to put the mine into produrtion. The most crucial of those are the water-discharge permits that would allow Sheep Creek to be dammed for tailings storage (Anchorage Daily News, May 1, 1993); t $?$ permits would require that any water released from $\mathrm{tl}:$ tailings ponds meet Federal water-quality standards. A c zalition of environmental groups has filed suit against the EPA and the ACE, claiming that the reservoirs created by the tailings dams should be classified as waste-treatmert facilities and that incoming water also needs to meet Federal waterquality standards (Juneau Empire, December 21, 1993). The EPA and ACE determined in October 1992 that permits were not required for dumping waste rocl or water behind tailings dams; the coalition claims that this decision was in violation of the Federal Clean Water Act. In addition to the permits, the Juneau Planning Commission wants the A-J Mine developer to carry insurance coverage of $\$ 50$ million in general liability and $\$ 30$ million in environmental liability (Anchorage Daily News, April 5, 19ऽ3).

The Alaska Division of Mining is performing reclamation work at the century-old Treadwell Mine on Douglas Island west of Juneau. Under the Abandoned Mine Lands program, five shafts will be capped and sealed with concrete, and a 15-meter fence will be constructed at the entrance of the mine's Glory Hole, a huge open pit from which more than 5 million tons of ore was removed. The project is expected to cost $\$ 200,000$. The Tread vell Mine opened in 1896 and reached peak production in 1915 (Anchorage Daily News, July 26, 1993).

On February 16, 1993, the Kennecott Gresns Creek Mining Company announced that the Greens Creek silverlead-zinc mine in southeastern Alaska would close for an unspecified period of time; the company ascribed the closure to depressed metals prices. A small work force was retained to maintain the mine and equipment, conduct environmental monitoring, and continue some unterground exploration. Greens Creek was the largest silver mine in North America and, in the first 3 months of 1993, produced 53,550 kilograms of silver (worth $\$ 7.4$ million), 8,606 metric tons of zinc ( $\$ 8.35$ million), 228 kilograms of gold ( $\$ 2.63$ million), and 3,186 metric tors of lead ( $\$ 1.26$ million). Mineable reserves have been estimated at 
11.34 million metric tons of ore, sufficient for a mine life of 30 years (Mining Journal, February 19, 1993). Final cost of mine development was estimated at $\$ 106$ million; annual payroll was about $\$ 12$ million. The mine was $\mathrm{Ju}-$ neau's largest private-sector employer.

On Chichagof Island, Apex-El Nido Mining has asked the ACE for a permit to build a dock near its claims on an abandoned gold mine, which the company hopes to revive. The Juneau-based company wants to sink a barge for use as a loading platform for exploration equipment. The mine was active between 1924 and 1935, producing more than 7,250 metric tons of ore containing 553,642 grams of gold. Based on recent exploration, the company estimates an average of 34 grams of gold per metric ton of ore (Fairbanks Daily News-Miner, January 27, 1993). The mine is on USFS land, and the agency is preparing an environmental assessment of the company's proposal.

\section{OTHER METALS}

The Red Dog Mine in northwestern Alaska is the largest zinc producer in North America. Owned by the NANA Regional Corporation and operated by Cominco Alaska, it is the largest operating lode mine in Alaska. The mine's zinc production in 1993 of 422,400 metric tons of zinc concentrate was the highest in the mine's history. The mine pays the Northwest Arctic Borough nearly $\$ 2$ million in taxes annually, about 80 percent of the borough's budget (Anchorage Daily News, March 8, 1993); the mine operator also makes annual payments to the mine owner. Cominco Alaska has appealed to the borough to accept reduced tax payments for the next 2 years in order to reduce its operating costs and offset depressed metals prices. The company estimates a breakeven zinc price of at least $\$ 1.21$ per kilogram; zinc prices had declined to approximately $\$ 0.97$ per kilogram, from roughly $\$ 1.70$ per kilogram when Red Dog's production began in the late 1980's (Alaska Journal of Commerce, October 18, 1993). The mine and infrastructure employ 385 people.

A $\$ 300,000$ exploration program of mineral test drilling near Lake Iliamna has turned up no new commercial deposits at Cominco's Pebble Copper deposit, about 320 kilometers southwest of Anchorage. Previous infill drilling of the deposit's higher grade core confirmed a resource of 60 million metric tons averaging 0.5 percent copper and 0.5 grams of gold per metric ton, which is contained within the overall deposit's probable resource of 455 million metric tons averaging 0.35 percent copper and 0.4 grams of gold per metric ton (Northern Miner, May 31, 1993; Anchorage Daily News, October 13, 1993). The 1993 exploration program revealed that, outside of the high-grade zone, copper and gold are evenly distributed throughout the rest of the porphyry-style deposit. The Peb- ble Copper claims are on Alaska State land and are held 100 percent by Cominco. Low metal prices do not justify the high costs of the mine's development.

Base-metal exploration was active on Prince of Wales Island in southeastern Alaska. American Copper and Nickel had programs at Hetta Inlet on the southwestern coast of the island, on land owned by Sealaska, a Native regional corporation (Northern Miner, May 31, 1993). Lac Minerals also conducted an exploration program of drilling, ground geophysics, and mapping at the I'iblack Anchorage massive-sulfide deposit on the southeastern coast of the island (Bundtzen and others, 1994).

The Midrex Corporation, an American subsidiary of Japan's Kobe Steel, issued a prospectus for a \$200-million iron-ore-reduction plant in south-central Alaska near the proposed Port MacKenzie in Upper Cook Irlet (Alaska Journal of Commerce, August 30, 1993). The plant would use natural gas as a chemical feed stock to create highgrade iron for steel production in the Far East. The AIDEA is studying the proposal for possible State funding (Alaska Journal of Commerce, April 5, 1993).

Klukwan Iron Ore planned to donate 6.5 square kilometers of iron-rich land in southeastern Alaska to The Nature Conservancy. After examination of the land by three large steel companies, the corporation has determined that it would be too expensive to develop the 907-million-metric-ton iron deposit. The patented mining claim s ultimately will be turned over to the State under protectec' status, and the land will be opened for public use (Anchrrage Daily News, December 9, 1993).

In southeastern Alaska, Skagway's ore terminal was shut down, and most of its workers were laid off, after a decision by Curragh Resources to shut down the Faro and Sa Dena Hes Mines in the Yukon Territory of Canada, mines from which lead and zinc ores were trucked to Skagway for shipping. The Toronto-based company also announced that it would seek Canadian court. protection that is the equivalent of a Chapter 11 bankrup+cy filing in the United States (Anchorage Daily News, Mry 7, 1993). Curragh had leased the Skagway terminal and adjoining fuel facilities from the AIDEA until the year 2023 and owes the AIDEA about \$22 million (Alaska Journal of Commerce, May 10, 1993). The Yukon government has offered to back a $\$ 29$ million loan to Curragh to keep the two mines operating (Alaska Journal of Commerce, March 29, 1993).

\section{ACTIVITY BY FEDERAL AGENCIES}

\section{U.S. GEOLOGICAL SURVEY}

All reports listed in the following eight sections on USGS activities are catalogued in appendix 1 under the USGS heading. 


\section{ALASKA MINERAL RESOURCE ASSESSMENT PROGRAM}

AMRAP studies are conducted at four progressively more detailed levels to produce comprehensive assessments of the mineral and energy resources of Alaska. Level I studies are statewide in scope, and published maps are generally at a scale of 1:2,500,000. A new State of Alaska Mineral Resource Assessment Program (SAMRAP) has been initiated to compile geologic and mineralresource data. The purpose of the assessment is (1) to prepare tables of significant lode and placer deposits by revising data from the MRDS into an Alaskan Resource Data File (ARDF); (2) to prepare regional maps, with data tables, showing permissive mineral-resource assessment tracts; and (3) to prepare quantitative estimates of the undiscovered resources of copper, lead, zinc, gold, and silver in selected mineral-deposit types for selected tracts. There are presently 2,380 records in the ARDF. SAMRAP involves members of the Branches of Alaskan Geology, Geophysics, Geochemistry, and Resource Analysis.

Level II studies address large parts of the State, and resultant maps are generally published at a scale of $1: 1,000,000$. Level II studies of geology and mineral resources are ongoing on the Alaska Peninsula and in the eastern Alaska Range.

Level III studies consist of multidisciplinary evaluations involving team studies of selected 1:250,000-scale quadrangles (fig. 12); these continue to be the primary focus of AMRAP. Areal assessments are based on the integration of geologic, geochemical, and geophysical data to estimate the probability of occurrence of certain mineral resources within delineated tracts of geologic favorability. Favorability is ranked as low, medium, or high, based on an evaluation of geologic features and attributes present within each tract. Fieldwork is complete, and reports are in preparation or in press, for the Baird Mountains, Bethel, Chandler Lake, Craig/Dixon Entrance, Goodnews Bay/ Hagemeister Island, Gulkana, Iditarod, Killik River, Lime Hills, Livengood, Port Moller/Stepovak Bay/Simeonof Islands, and Survey Pass quadrangles. Fieldwork will continue, as funding permits, in the Atlin/Juneau/Skagway/ Taku River, Howard Pass, Sitka, and Sleetmute (fig. 13) quadrangles. A new geologic map of the Livengood quadrangle in east-central Alaska serves as an up-to-date interpretation of the geology in support of the mineral resource assessment (Weber and others, 1992). A preliminary geologic map of the Bethel and southernmost Russian Mission quadrangles was released in 1993 (Box and others, 1993). To date, Level III AMRAP assessments have been completed for 34 quadrangles. There now have been approximately 715 reports published under AMRAP.

Level IV studies consist of areal mineral-resource assessments, framework or process studies, and exploration geochemistry; projects incorporate detailed mapping (1:63,360 or larger scale), sampling of individual mineral deposits or mining districts, and related field and laboratory research. Ongoing Level IV activities in Alaska (fig. 14, table 9) include four projects that are statewide in scope; four studies of general geology, mineral resources and deposits, and metamorphic terranes in the central and western Brooks Range; a study of lode-gold veins on the Seward Peninsula; five studies of mineral resources and the geologic evolution of eastern and south-central Alaska; four studies of general geology and mineral resources in southwestern Alaska; and six studies of precious- and base-metal deposits in southeastern Alaska.

The annual report on USGS field and laboratory studies of mineral and energy resources and the geology of Alaska has been issued for 1992 (Dusel-Bacon and Till, 1993). Mineral-resource studies in this publication include reports on metallic-mineral resources in the Horn Mountains,

Table 9. Level IV studies of the USGS Alaska Mineral Resource Assessment Program and related projects active in 1993.

[Project chiefs are listed in parentheses. Projects marked by asterisk are of statewide scope; other locations shown on figure 14]

Areal mineral-resource assessments

Alaska Peninsula, geology and mineral resources (F.H. Wilson)

Aleutian Islands, geology and mineral resources (F.H. Wilson)

Chugach Special Study Area, geology and mineral resources (S. Nelson, USGS; G. Sherman, USBM)

Eastern Alaska Range, metallogenesis (W.J. Nokleberg)

Fortymile Mining District, placer gold deposits (W.E. Yeend)

Juneau Gold Belt, lode gold deposits (R.J. Goldfarb)

NPRA/Colville Mining District, geology and mineral resources (J.H. Dover, USGS; S. Fechner, USBM)

Norton Bay-Unalakleet area, geology and mineral resources (W.W. Patton, Jr.)

* Placer gold deposit studies (W.E. Yeend)

Western Brooks Range, mineral deposits (J.M. Schmidt)

Framework or process studies

* Alaska mafic and ultramafic rocks (R.A. Loney)

* Alaska metamorphic-facies map (C. Dusel-Bacon)

Central Alaska metamorphic studies and structural analysis (J.H. Dover)

Chugach massive sulfide deposits, geochemistry (S.W. Nelson)

Greens Creek lead-zinc-silver massive-sulfide deposit (R.S. Newberry and D.A. Brew)

Groundhog Basin-Glacier Basin silver-tin-lead-zinc (R.J. Newberry and D.A. Brew)

Jualin and Kensington low sulfide gold-quartz-vein deposits (R.S. Newberry and D.A. Brew)

Northwestern Alaska crustal study (A.B. Till)

* Paleomagnetism of accreted terranes (C.S. Gromme)

Salt Chuck platinum-palladium deposits (R.A. Loney)

Seward Peninsula gold veins (B.M. Gamble)

\section{Exploration geochemical studies}

Western Brooks Range, stratabound base-metal deposits (K.D. Kelley) Southwestern Alaska, epithermal mercury deposits (J.E. Gray)

Admiralty Island geochemistry (C.D. Taylor) 


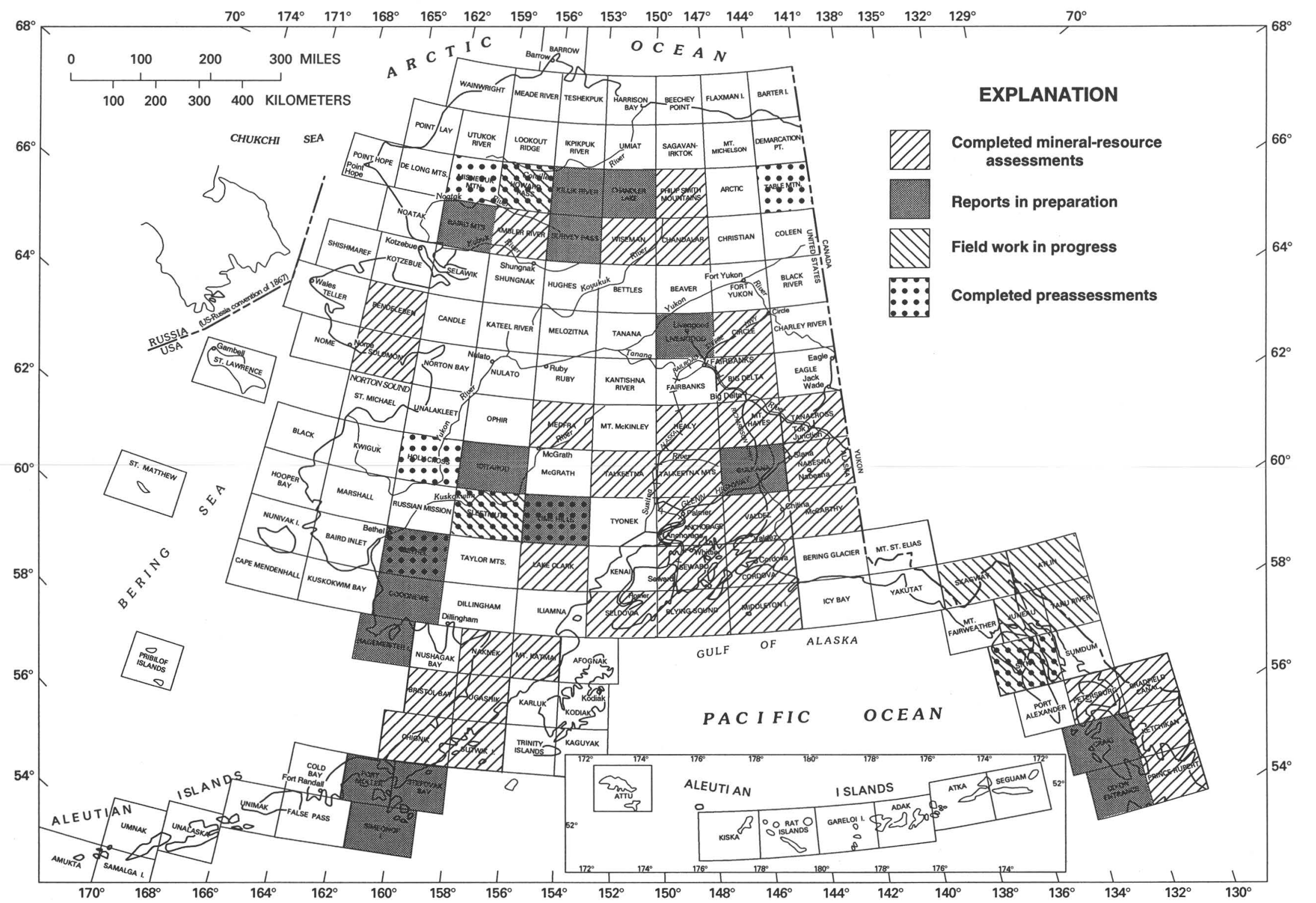

Figure 12. Status of USGS level III AMRAP quadrangle studies as of January 1994. 1:250,000-scale quadrangles are outlined and labeled. 
Sleetmute quadrangle (Gray and others, 1993); gold and cinnabar in stream-sediment samples from the Lime Hills quadrangle (Eppinger, 1993); ore deposition in the Chugach and Prince William terranes (Haeussler and Nelson, 1993); a geochemical evaluation of stream-sediment data from the Bering Glacier and Icy Bay quadrangles (Goldfarb and Borden, 1993); newly discovered molybdenite occurrences at Dora Bay on Prince of Wales Island (Philpotts and others, 1993); and rubidium-strontium isotopes in vein minerals in the Juneau Gold Belt (Kistler, Newberry, and Brew, 1993).

PRECIOUS METALS

USGS geologists are involved in two studies of precious-metal occurrences in Alaska. A comprehensive study of the Fortymile Mining District covers placer geology,

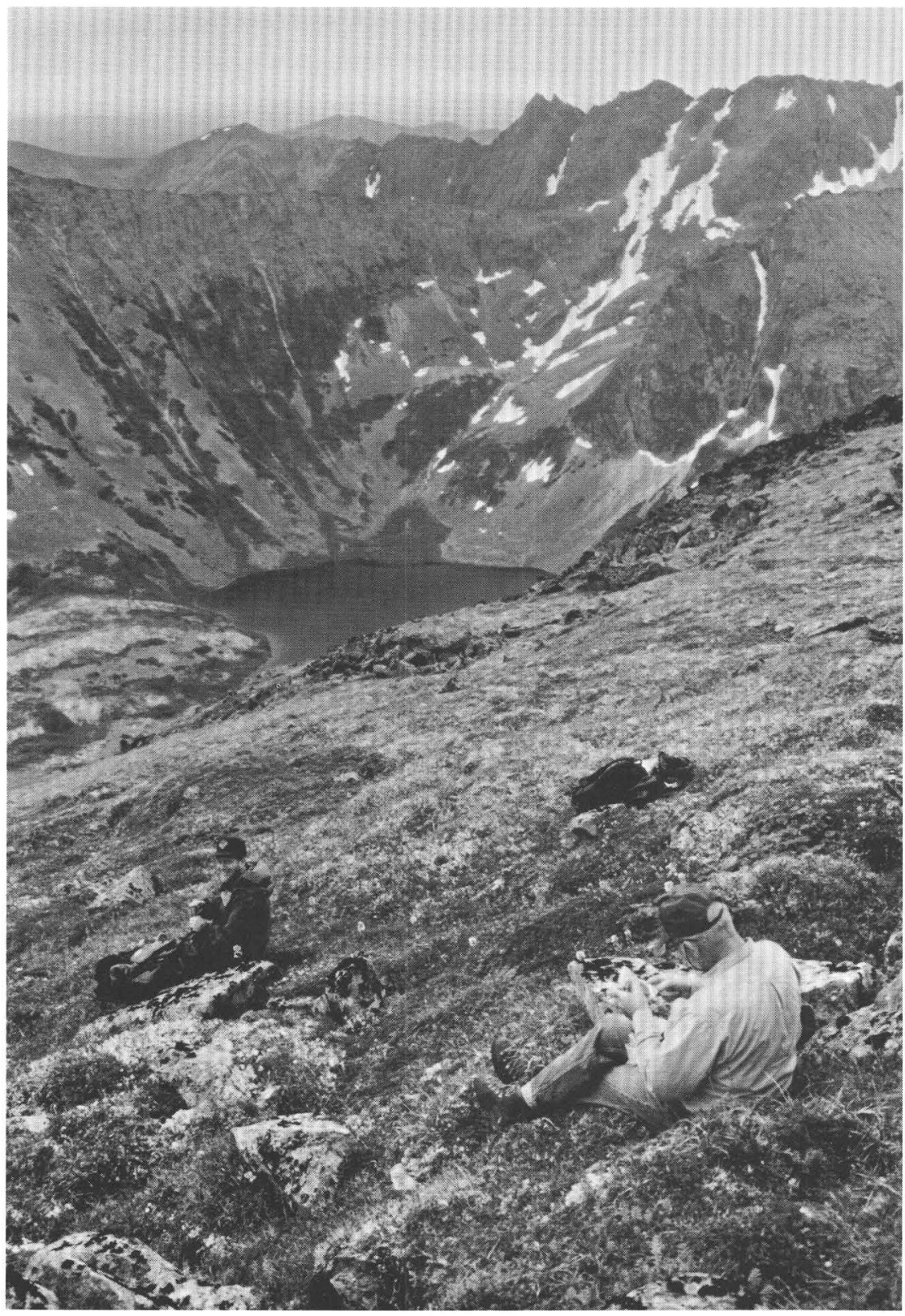

Figure 13. USGS geologists map rugged terrain of Kiokluk Mountains in the Sleetmute quadrangle of southwestern Alaska as part of level III AMRAP studies. Photograph by M. Miller. 


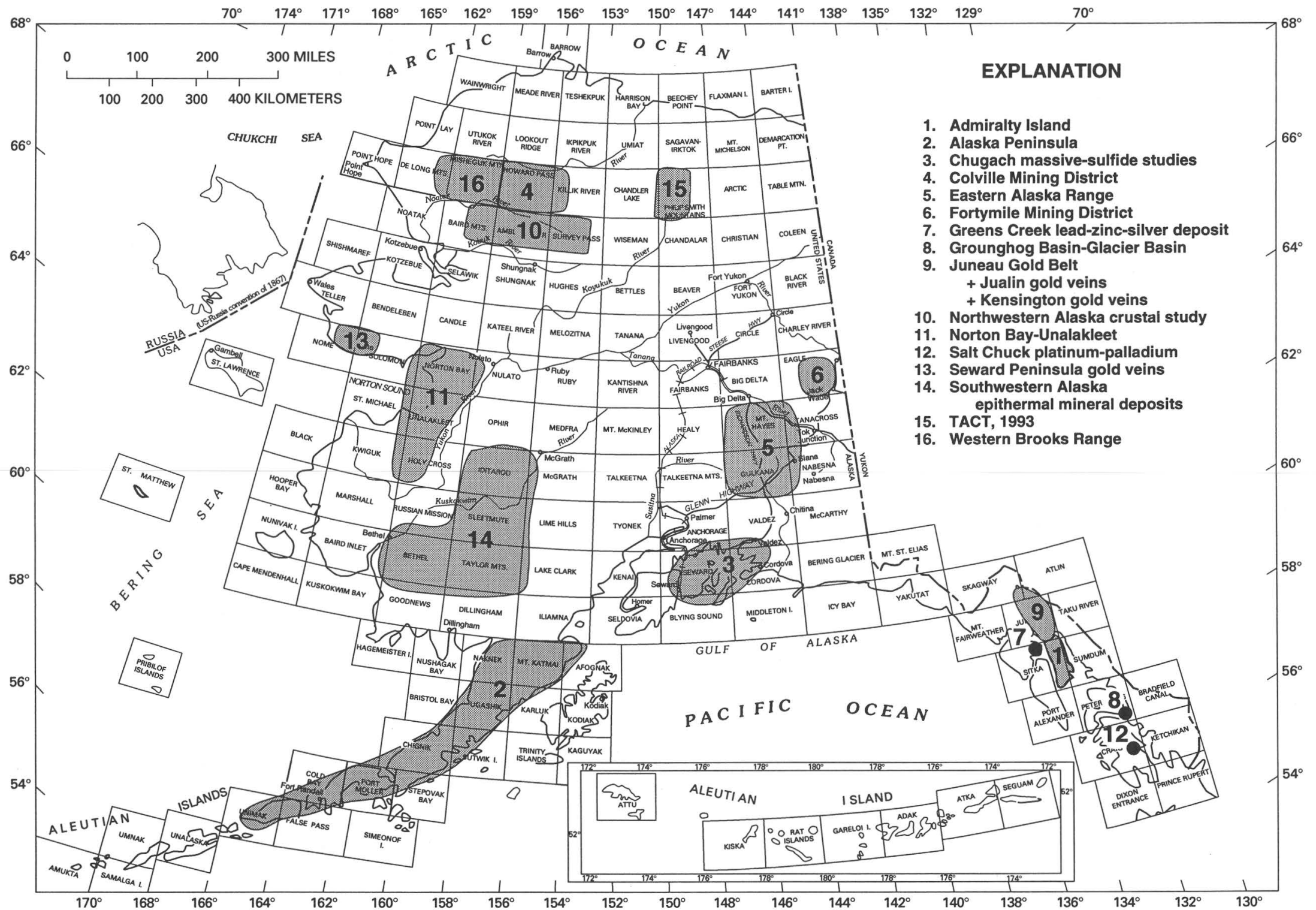

Figure 14. Locations of USGS level II and level IV AMRAP metallic-mineral studies and TACT studies in 1993. 1:250,000-scale quadrangles are outlined and labeled. 
heavy minerals, bedrock geology, stream and terrace profiles, gold source and resource, and current mining operations, as well as a history of mining in the region on a creek-by-creek basis (fig. 15); the report is completed and in review. A second study focuses on the structure, tectonic setting, and origin of turbidite-hosted lode-gold deposits in the Kenai and Chugach Mountains.

\section{STRATEGIC AND CRITICAL MINERALS}

Current research on the occurrence of undiscovered strategic and critical minerals in Alaska includes studies of mafic and ultramafic rocks and their associated deposits of platinum-group metals (PGM), chromium, nickel, and cobalt.

\section{ENVIRONMENTAL STUDIES}

Because mercury is highly toxic both in its elemental state and as organic compounds, hazards related to natural occurrences of mercury are being investigated as part of the Sleetmute AMRAP in southwestern Alaska. The Sleet- mute quadrangle contains the Red Devil Mine, Alaska's largest mercury mine, and lies within a regionally extensive belt having a naturally elevated mercury content. The mercury occurs primarily in cinnabar (mercury sulfide), but native mercury has been reported from three prospects and locally forms pools in the stream beds below mineralized outcrops. A man made mercury hazard may also have developed as a result of gold-placer mining in the region: mercury can be used to physically trap small particles of gold during the mining process, and some placer sites may have been contaminated with unrecovered mercury from this operation. Geochemical analyses of soil and stream sediments are being performed to pinpoint areas of high mercury levels, but in some cases, it may not be possible to determine whether the hazard is natural or man made.

\section{COOPERATIVE PROGRAMS WITH FOREIGN SCIENTIFIC AGENCIES}

The governments of the United States, Russia, and Canada have undertaken a cooperative study to decipher and characterize the metallogenesis and tectonic history of the Russian Far East, Alaska, and the Canadian Cordillera.

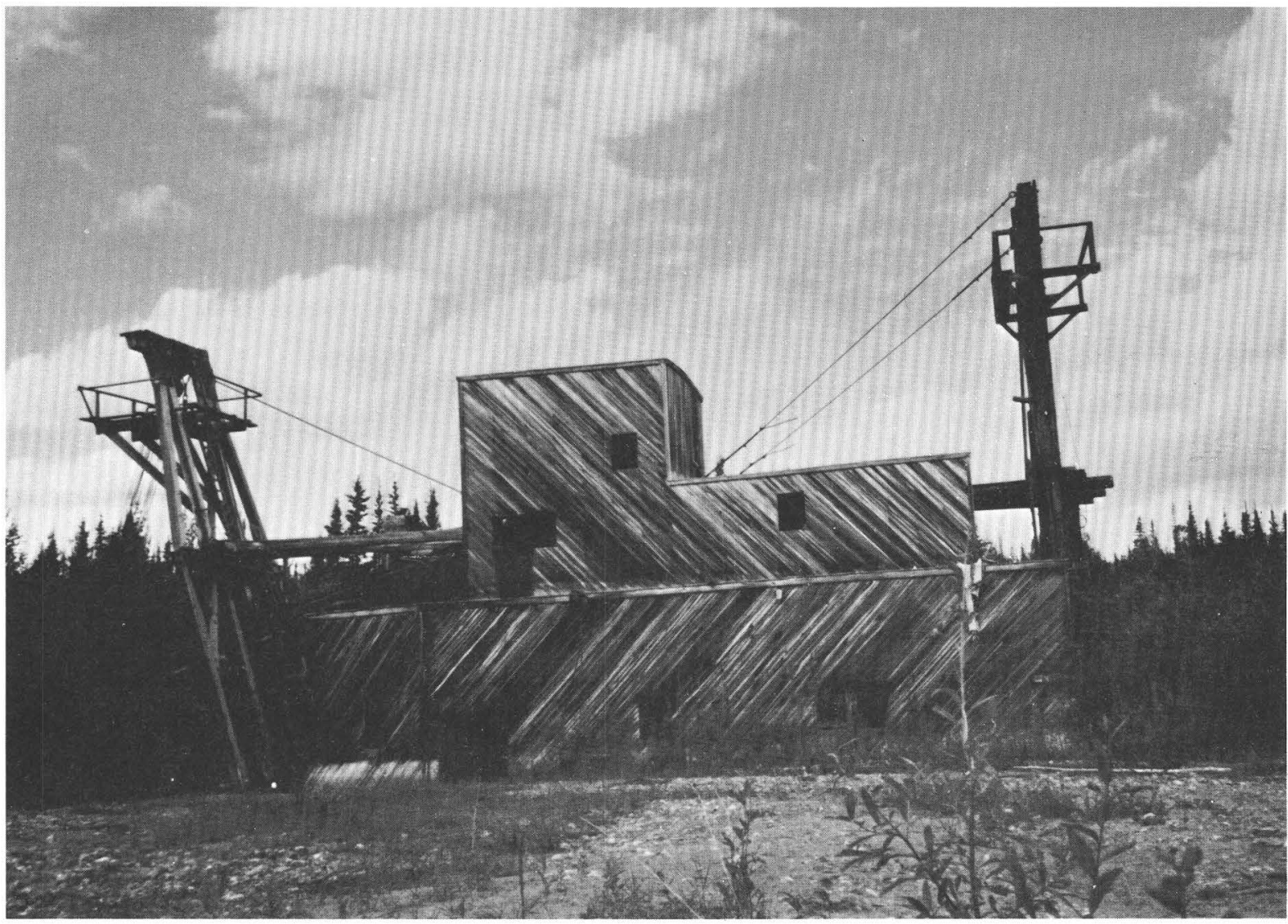

Figure 15. Abandoned dredge in Fortymile Mining District. Photograph by W. Yeend. 
Work on the project began in 1989 and continues to the present. A report on the metallogenesis of mainland Alaska and northeastern Russia (Nokleberg, Bundtzen, and others, 1993 ) is the first in Western literature to document the significant mineral deposits of the Russian Northeast and to correlate Russian mineralized belts with similar belts in Alaska. The report provides (1) location maps and detailed tabular summaries of the significant lode deposits and placer districts in Alaska and the Russian Northeast, (2) summaries of the mineral deposit types or models that occur in the two regions, and (3) an interpretative synthesis of the origin of the metallogenic belts and their relation to host rocks. As a scientific collaboration among the USGS, the ADGGS, the Russian Academy of Sciences, and the Geological Committee of Northeastern Russia, this publication is notable because the Russian mineral data previously had been classified as state secrets by the Soviet government. The Russian Northeast holds great potential for the discovery of new mineral deposits and for the employment of Western technology in developing new mines, reprocessing old mine dumps, and cleaning up abandoned mine sites.

The U.S. State Department awarded an $\$ 84,000$ grant to the project in 1993 (1) for the development of a three-dimensional time-space model for the metallogenesis and tectonic history of the Russian Far East, Alaska, and the Canadian Cordillera, (2) for the purchase of computer equipment and software at four Russian institutes to facilitate publication of the reports and maps in Russian, and (3) for project work and travel to scientific meetings. The North American team traveled to the Russian Far East in August for map compilation and mine field trips, and seven Russian team members attended and presented papers at the Northwest Mining Association's annual meeting in Spokane, Washington.

A collaborative study of the ophiolitic terranes in Alaska and northeastern Russia is also ongoing. In Alaska, the study includes ophiolites of the western Brooks Range, Yukon-Koyukuk basin, Yukon-Tanana crystalline block, Goodnews Bay region, Border Ranges fault zone, and Gulf of Alaska coastal areas; in northeastern Russia, the study encompasses the Koryak Uplands, the Annyui region, and eastern Chukotka. A synthesis map of ophiolitic terranes in both regions will be published at a scale of 1:2,500,000, and tables will summarize the geologic setting, petrography, geochemistry, and mineral deposits of the terranes. The geologic map showing ophiolite complexes of the Koryak Highland, Chukotka, and the South Anyuy suture zone in northeastern Russia was recently issued (Khanchuk, Palandzjan, and Panchenko, 1994); the Alaskan components of the project were released in 1992 (Schneider, 1993).

\section{TRANS-ALASKA CRUSTAL TRANSECT (TACT)}

The TACT program is an integrated, multidisciplinary study of the Earth's crust along a transect from the
Gulf of Alaska to the Arctic Ocean. The program combines data from geologic and geophysical surveys to decipher the deep-crustal structure of Alaska. Research includes (1) geologic mapping, (2) specialized structural, isotopic, geochemical, and paleontologic studies, (3) seismic reflection and passive seismic studies, (4) magnetotelluric studies, and (5) gravity and magnetic surveys. Although mainly a deep-crustal structure program, results from the TACT program are used for mineral-resource assessment studies, formulation of tectonic models of mineralization, and minerals exploration by private industry. Synthesis and interpretation of geophysical data continued in 1993, and three papers were published (Beaudoin and others, 1993; O'Sullivan and others, 1993; Pavlis and others, 1993).

\section{COLVILLE MINING DISTRICT}

At the request of the BLM, a cooperative 4-year investigation of the nonfuel-mineral resources in the Colville Mining District, located in the southern half of NPRA, was initiated by the USGS and the USBM in 1990. The study will evaluate the mineral potential of the district in order to aid the BLM in its land-planning decisions. The evaluation will include USGS estimates of undiscovered mineral resources and a USBM compilation of data on known deposits. Fieldwork in 1993 included detailed geologic mapping, structural analysis, geochemical and paleontologic sampling, and stratigraphic investigations.

\section{CHUGACH NATIONAL FOREST SPECIAL STUDY AREA}

At the request of the USFS, the USGS and USBM are collaborating in an estimation of the undiscovered and discovered mineral endowment of a selected area in the Chugach National Forest between Unakwik Inlet and the Columbia Glacier in Prince William Sound. The investigation includes geologic mapping, prospect evaluation, rock and stream geochemistry, structural analysis, geochronology, and isotopic studies. Two reports have been published (Haeussler and Nelson, 1993; Nelson, 1993), and a map is planned for release in late 1994 . The study results will be incorporated into the Chugach National Forest Management Plan, a part of which seeks to develop and maintain an inventory of all resources, including mineral values.

\section{U.S. BUREAU OF MINES}

The USBM's AFOC is responsible for conducting four programs under the USBM's Directorate of Information and Analysis and for coordinating work with other USBM field and research centers throughout the United States. The USBM's Research Directorate was responsible 
for several projects in Alaska during 1993, through both the Mineral Institute Program and the nine USBM research centers. All reports listed in the following five sections on USBM activities are catalogued in appendix 1 under the USBM heading.

\section{MINERALS AVAILABILITY PROGRAM}

Submarine tailings disposal.-In many coastal mining situations, the submarine burial of ore tailings may be the preferred method of disposal from an environmental standpoint. In 1991, the USBM initiated studies to assess the technology, environmental aspects, and current regulations relating to this method of tailings disposal, and to project effects on the availability of minerals from domestic sources if this disposal technique were permissible in the United States. Published reports include: (1) an overview and bibliography of submarine tailings disposal (Baer, Sherman, and Plumb, 1992), (2) a compilation of case studies of North American submarine disposal sites (Poling and others, 1993), (3) the regulatory aspects of the 14-year attempt to obtain operating permits for submarine tailings disposal at the proposed Quartz Hill Mine (Hesse and Reim, 1993), and (4) an analysis of mineral deposits whose development could benefit economically from the use of submarine tailings disposal (Coldwell and Gensler, 1993). Seven known mineral deposits on Alaska's southern coast are described in this last publication. Future USBM reports will cover the technology and environmental aspects of submarine tailings disposal, a compilation of examples of submarine disposal outside North America, and a literature review of the biological effects related to submarine disposal.

Alaskan cost factors.-The USBM developed a comprehensive set of cost escalation factors for use in performing development feasibility studies on Alaskan mineral deposits. The factors allow for the escalation of capital and operating costs from Denver-based values to reasonable cost estimates for any region in Alaska (Balen and Allen, 1993).

Ore characteristics.-The USBM is compiling a data set outlining ore mineral characteristics that are specific to mining and milling scenarios for a given commodity; information on costs and engineering is also included. These data will provide for the rapid analysis of mineralrelated issues and policies.

Public information.-The MAS data base was enhanced by the entry of information from the Ketchikan Mining District and the Commonwealth of Independent States (CIS). A report describing the major CIS mineral deposits, arranged by commodity, is scheduled for publication in 1994. A system of generating commodity maps was developed using a GIS and should be adaptable to any region, including Alaska. Mineral data were provided in digital format and as map overlays and deposit reports to the State of Alaska, the USFS, mineral consultants, and private individuals.

\section{POLICY ANALYSIS}

Mine permitting in Alaska and British Columbia.Canada and the United States both have well-developed regulatory systems for permitting a mine; part of the process evaluates the anticipated environmental imparts of the proposed operation. Objectives of the USBM study are (1) the compilation of detailed case studies of mine rermitting requirements and processes, and (2) a comparative analysis of the environmental regulatory structures and permitting required for mine development in Alaska and British Columbia. The USBM recently released the international comparative analysis (Cocklan-Vendl and Hemming, 1993) and a case study of permitting for the Greens Creek Mine (Andrews, 1993). Other case studies and a preliminary analysis of the effects of environmental regulation on mines in southeastern Alaska were released in 1992 ( $\$$.hneider, 1993).

Ecosystem-based regulation and the mining industry.-Federal land management agencies are inccrporating the concepts of ecosystem management into th sir landplanning and management efforts. The USBM is developing an analytical framework for evaluating the miningrelated implications of these proposed polisies and regulations. An initial study was undertaken to determine the effect that ecosystem management concepts have had on the environmental permitting process for maior mines in Alaska; a generalized flow chart of the mines' permitting was developed (Plumb and Gensler, 1993). A second study, to be released in 1994, used environmental data from the USFS and impact analysis models from other agencies to model a GIS description of the ecosystem surrounding the Greens Creek Mine in southeastern Alaska.

STATE MINERAL ACTIVITIES

The annual preliminary "Mineral Industry Survey of Alaska in 1992" summarized significant nonfuel-mineral activity. State legislative and executive actions cf interest to the mineral industry were monitored and reported throughout the USBM on a monthly basis. News items were prepared for the weekly "Mineral Alerts" and for the bimonthly survey "Minerals and Materials." Mineral briefing profiles were prepared for DOI and USBM officials as required. Mineral news of interest to USBM staff and its commodity specialists was forwarded to them weekly.

Minerals information and analysis are provided through a series of scheduled and unscheduled publications and reports and through responses to inquiries from State and Federal agencies, industry, and the public. One priority is the identification and evaluation of issues, prob'sms, and 
trends, in order to provide the USBM additional opportunities for constructive action in the minerals field.

\section{MINERAL LAND ASSESSMENT}

USBM mining district studies (fig. 16, table 10) are designed to determine the mineral-development potential of each district by inventorying mineral resources and reserves, evaluating the probability that more resources exist, and determining the feasibility of mining certain deposit types. Site-specific evaluations are undertaken when the presence of significant minerals is noted. The studies are done in cooperation with Federal and State agencies, and summary reports are issued annually (Bittenbender and others, 1993; Meyer, Kurtak, and Hicks, 1993). In 1993, the USBM investigated the Colville and Ketchikan Mining Districts, the Gulf of Alaska, the Chugach National Forest, and two BLM planning units. The USBM also is assessing abandoned mine hazards for the USFS.

Colville Mining District.-The Colville Mining District is located in northern Alaska and includes the southern part of NPRA. During 1993, the third and final year of the field program, the USBM investigated the area from the Dalton Highway to Chandler Lake. Reconnaissance work investigated previously identified drainages containing anomalous metal values, and detailed mapping and sampling were conducted at known mineral sites. A total of 487 rock, soil, and stream-sediment samples were collected. Quartz veins were found containing sphalerite, ga-

Table 10. USBM study areas in 1993.

[Locations shown on figure 16. REE, rare-earth elements; PGM, platinum-group metals]

\begin{tabular}{lc}
\hline \multicolumn{1}{c}{ Area of study } & Deposit or element of major interest \\
\hline \multicolumn{1}{c}{ Mining Districts } \\
\hline $\begin{array}{l}\text { A. Colville Mining District } \\
\text { B. Ketchikan Mining District }\end{array}$ & $\begin{array}{c}\text { Lead, zinc, barite, phosphate, coal } \\
\text { Placer and lode gold, massive sul- } \\
\text { fide, chromium, REE, PGM }\end{array}$ \\
\hline Site-Specific Mineral Investigations \\
\hline $\begin{array}{l}\text { C. Gulf of Alaska } \\
\text { Chugach National Forest }\end{array}$ \\
\hline \begin{tabular}{l} 
D. Abandoned-mine land hazards \\
\hline
\end{tabular}
\end{tabular}

BLM Planning Units

F. Fortymile River/Black River units lena, and chalcopyrite; sphalerite-bearing concretions were discovered in the Kayak Shale; and phosprate-bearing rocks were mapped in the Alapah Limestone of the Lisburne Group. Some phosphate samples contain ad up to 30 percent $\mathrm{P}_{2} \mathrm{O}_{5}, 119$ parts per million (ppm) uranium, and 2,000 ppm vanadium; samples from one 7-meter-thick bed averaged 22 percent $\mathrm{P}_{2} \mathrm{O}_{5}$. Bulk samples from two zinclead-silver veins and two phosphate occurrences were sent to USBM research facilities for beneficiation and characterization studies.

Ketchikan Mining District.-Fieldwork concluded in the Ketchikan Mining District of southeastern Alaska. Studies indicate that the district is endowed with a diverse array of lode deposits that include gold, silver, copper, lead, zinc, molybdenum, tungsten, PGM, rari-earth elements (REE), iron, chromium, and titanium. The USBM examined 155 mineralized localities, collected 880 samples, and mapped 6,297 meters of underground and surface workings in 1993. Three metallurgical test samples were collected. The work delineated (1) a highly anomalous platinum area on Mt. Burnett, (2) porphyry molybdenum mineralization in Ketchikan that is similar in character to the world-class Quartz Hill deposit, and (3) ban ted sulfides in the Hyder area that resemble those found at the nearby, highly productive Premier Gold Mine (fig. 17).

Site-specific mineral investigations.-Through field studies, deposit modeling, and beneficiation and metallurgical testing, the USBM conducts site-specific in"estigations to locate, characterize, and quantify deposits that contain strategic and critical minerals and advanced materials. The USBM has investigated occurrences of chromium, cobalt, gallium, germanium, indium, manganese, niobium, PGM, REE, tantalum, tin, vanadium, yttrium, and zirconium at nearly 300 sites in Alaska. Currently, the USBM is evaluating the development potential of Alaska's indium and titanium resources. A report on indium in hydrcthermal tin deposits in Alaska is due in 1994.

During 1992 and 1993, the USBM and the USGS cooperatively investigated the titanium resource? of onshore marine placer deposits along the Gulf of Alaska. More than 8 metric tons of hand-auger, power-auger, stream-sediment, and channel samples were collected from modern and former shoreline deposits. Results of the 1992 work have been released (Fechner and others, 1993), and laboratory studies of chemical analyses, flotation tests, and mineral characterizations will be published in 1994.

Unakwik mineral occurrences.-The USFS requested the USGS and the USBM to conduct geologic investigations in an area of the Chugach National Forest between Unakwik Inlet and Prince William Sound (fig. 18). Fieldwork was completed in 1992, and a summary report describing mineral occurrences and sample results is scheduled for publication in 1994. The results of the joint study will be used in the revision of the Chugech National Forest Management Plan. 


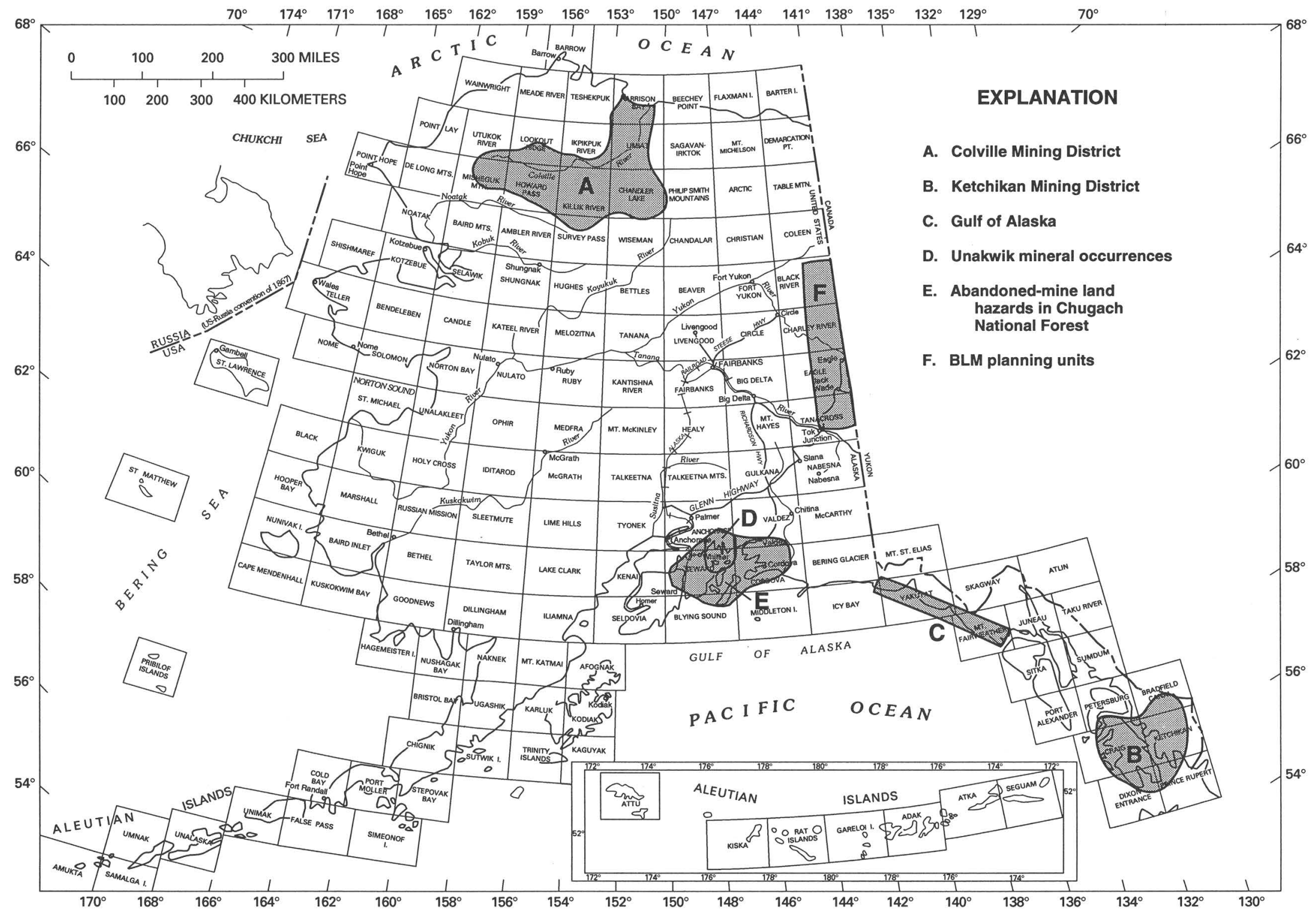

Figure 16. Locations of 1993 USBM study areas listed in table 10. 1:250,000-scale quadrangles are outlined and labeled. 
BLM planning studies.-The BLM requested the USBM to conduct a mineral-resource inventory of the Fortymile River and Black River planning units; the inventory will be incorporated into the units' Resource Management Plans. The USBM conducted literature research and fieldwork in 1993, the first year of the 3-year study. Most of the known mineral properties were examined, and 460 samples were collected. Results of the 1993 work will be released in 1994.

Abandoned-mine land inventory.-In 1989, the USFS requested the USBM to locate and assess the physical and environmental hazards associated with abandoned mines in the Chugach National Forest. Potential hazards at abandoned-mine sites include explosives, underground workings, collapsed structures, and process chemicals. A cursory evaluation of the mine sites indicated that 100 properties contained potentially serious hazards. The USBM visited 9 high-priority sites in 1993, and a formal agreement with the USFS increased the number of sites to be visited in 1994 to 60 . The USBM also is developing a computerized data base of the abandoned-mine sites and their hazards. An inventory of hazards in the Tongass National Forest is slated to begin in 1995 (frontispiece).

\section{MINERALS RESEARCH}

Mine closure in arctic and alpine environments.The goal of this research was the development of reclamation technology for placer mines situated in fragile environments. The project concentrated on field evaluations of emerging technologies and innovative methods that deal with the reclamation problems associated with placer mines: stream diversion, slope recontouring and revegetation, habitat enhancement, and mining for maximum resource recovery in order to avoid future disturbance once an area is reclaimed. Many of the techniques were developed by small mine operators, regulatory agencies, and equipment entrepreneurs. The research has been completed, and final reports are in progress. The work was done in cooperation with the BLM, USFS, Alaska Division of Mining, Montana Bureau of Mines, Oregon Division of Geology, and Alaska Miner's Association.

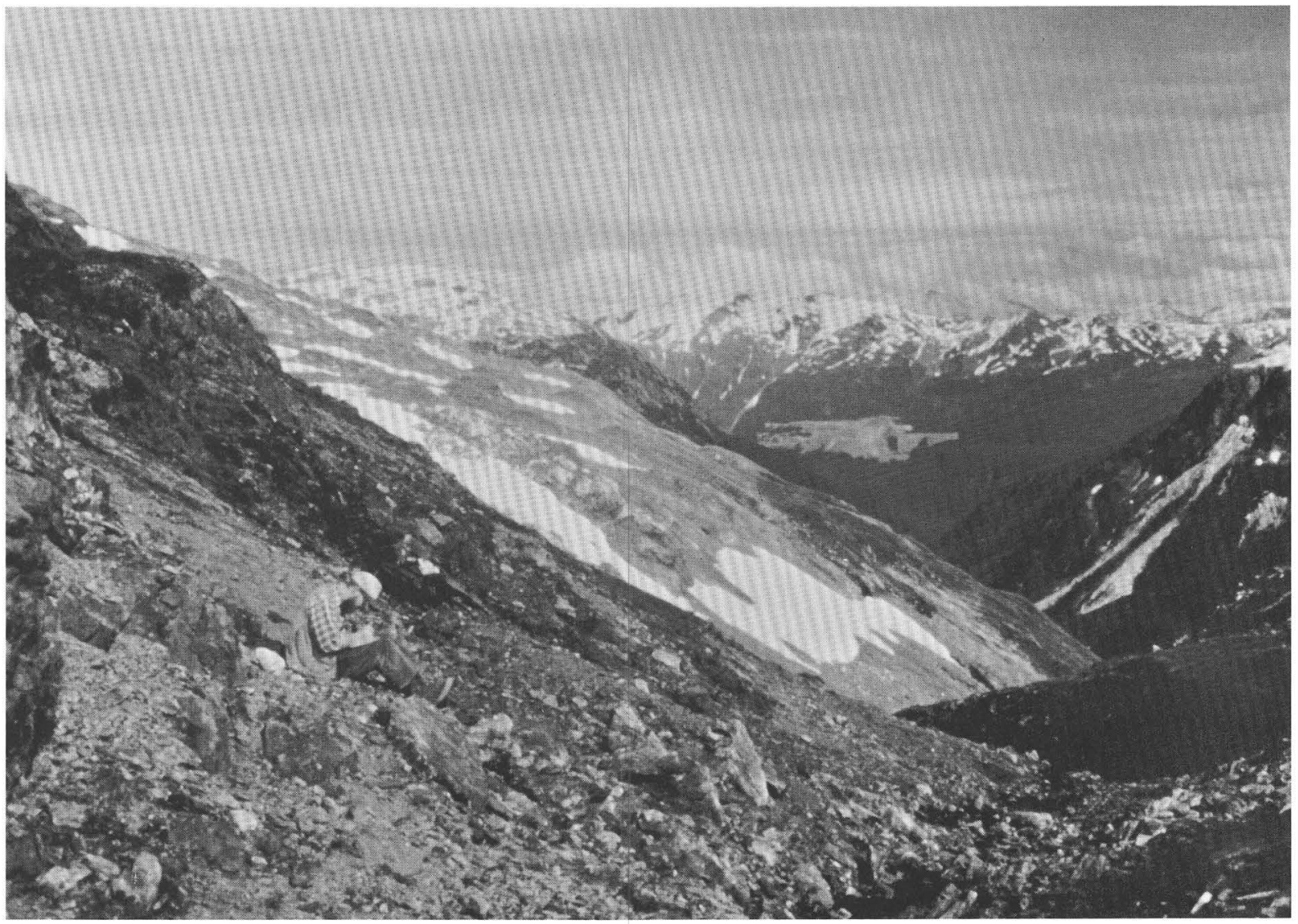

Figure 17. USBM geologist examines banded-sulfide mineralization in Hyder area of Ketchikan Mining District. The mineralization is similar in type and age to that found at Premier Gold Mine in British Columbia, Canada, visible in center background of picture. Photograph by J. Still. 
Subaqueous disposal of mining wastes.-This project addresses the environmental feasibility of disposing mineral-processing wastes into a marine environment. Most research indicates that the environmental viability of subaqueous disposal is ore-specific and that oxidation of sulfide minerals and acid production are minimized. However, some minerals can be sparingly, yet unacceptably, soluble. For research purposes, samples were collected of tailings from which all sulfide minerals had been removed as part of a proposed beneficiation procedure. The samples were placed in aquariums, covered with seawater to simulate submarine disposal, and subjected to variable physicochemical conditions. With the exception of minor amounts of manganese, no contaminants were released into the surrounding water. During 1994, pore water from within these samples will be analyzed to determine any dissolved metal contents, and toxicity tests will be conducted. If results are negative, a site test would place similar tailings samples in a real marine environment in order to study pore-water chemistry, toxicity, and recolonization characteristics.

Analysis of underground mining.-The goal of this project is the evaluation of new mining technologies as applied to mining in Alaska for maximum resource recovery and minimal waste and environmental impact. Computer-generated mining simulations are used to evaluate alternative mining methods without costly field development and testing. Ultimately, these modeling techniques will be used to design mines that optimize resource recovery, ensure workers' health and safety, and minimize environmental impact. Geotechnical data is being gathered from the Greens Creek Mine in southeastern Alaska to verify the computer simulations.

Mining in permafrost.-This project strives to develop safe, economic, and environmentally sound techniques for mining in permafrost. To study the structural stability of underground openings excavated in frozen ground, instruments were installed in a room-and-pillar section of the Dome Creek drift mine, a small underground placer operation near Fairbanks. Preliminary results have demonstrated that (1) the instruments and data acquisition system functioned properly despite the subfreezing temperatures, (2) vertical displacement of the mine roof was dependent on the span of the underground opening and proximity to active mining, and (3) significant stress changes occurred

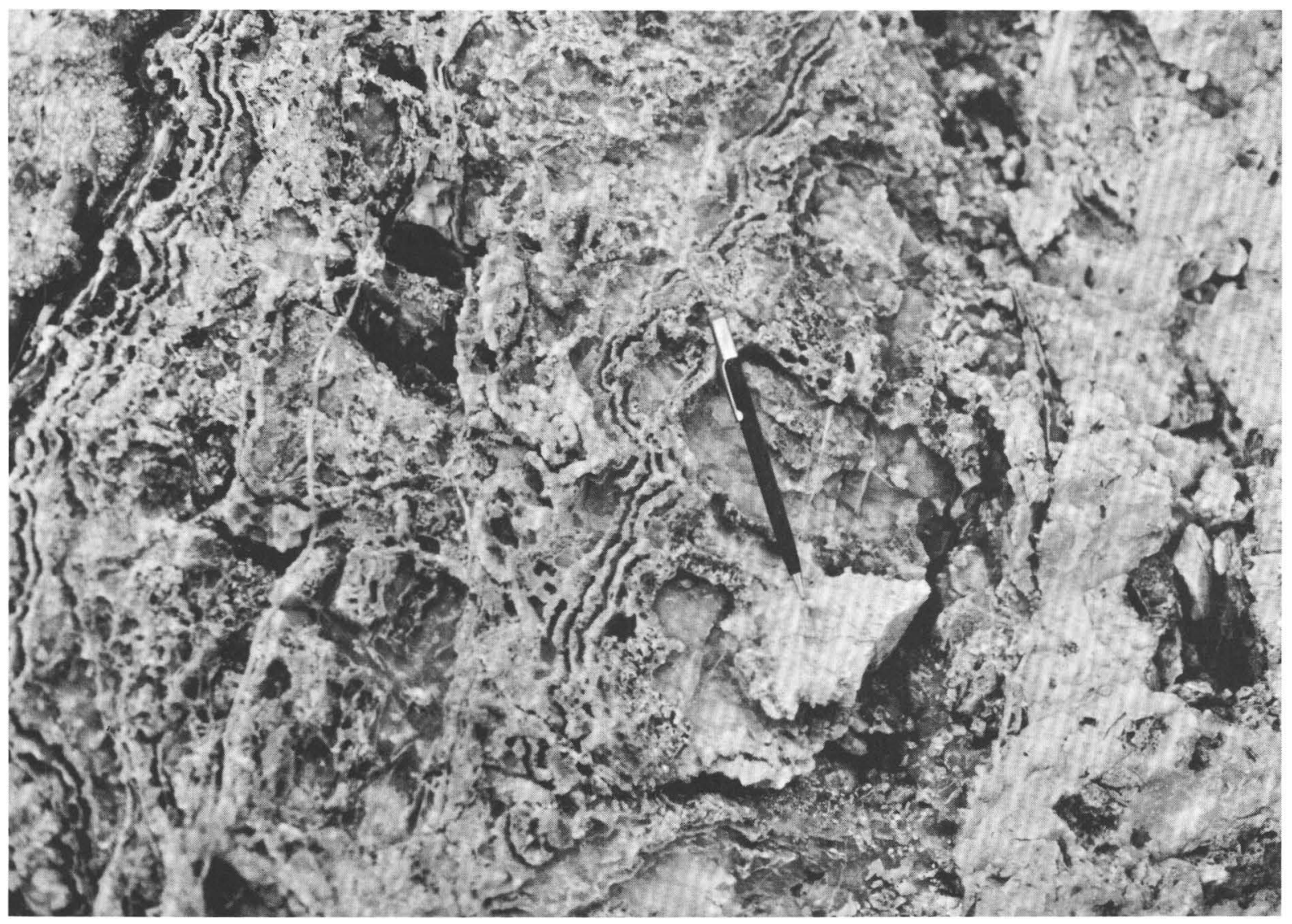

Figure 18. Quartz-fluorite vein, Chugach National Forest special study area. USBM and USGS geologists evaluated the mineralresource potential of this area for the U.S. Forest Service. Photograph by S. Nelson. 
in permafrost gravel, even though this material has a low modulus of deformation and exhibits a creep-type behavior. Researchers are continuing to analyze the field data collected from these instruments.

Borehole slurry mining.-The 1992 Alaska field test of a prototype Borehole Placer Mining System revealed a problem caused by cobbles clogging the slurry inlet pipe. In 1993, a redesigned borehole miner was tested under full-scale simulated mining conditions in gold-bearing frozen gravels at the USBM's Minnesota research facility. The tests were successful, and plans were made to test the borehole miner near Fairbanks in the summer of 1994.

Frozen tailings as backfill material.-Disposal of frozen tailings and waste rock as backfill material in underground mining operations is being assessed. Chemical stability of the fill material is a factor in evaluating its potential for long-term deposition. Cyclic freeze-thaw tests were conducted on placer gravel samples to simulate the seasonal temperature variations that could affect frozen backfill. Test results showed minimal mobilization of the samples' residual metals, nor did the presence of dissolved salts in the saturation solution affect the freezing of the material or the solubility of the metals. Continuing research will investigate the effect of acidity on the chemical stability of frozen fill materials.

Process mineralogy of Alaskan resources.-More than 8 metric tons of beach sands was analyzed in an investigation of titanium-bearing placers along the eastern Gulf of Alaska from Cape Yakataga to Cape Spencer. Detailed characterization revealed that ilmenite, zircon, and rutile grains from the Cape Yakataga area contain intergrowths of calcium- and magnesium-bearing minerals that could interfere with the $\mathrm{TiO}_{2}$-producing chlorination process. Current research is focused on the Yakutat area, where the heavy-mineral content of the beach sand is higher, and the beaches are broader, than the Cape Yakataga area.

Mineral characterization and beneficiation studies were completed on samples from the Story Creek leadzinc deposit in the Colville Mining District (Summers, Larson, and Werdon, 1993). Mineralogical studies of the Ivotuk Hills phosphate samples show that the rock is approximately 73 percent apatite, and chemical studies show that vanadium tends to concentrate in the earthy-appearing areas of ooliths and also in dolomitic calcite, both between and within the phosphatic ooliths.

Evaluation of Alaskan strategic and critical resources.-Four precious-metal ores from Prince of Wales Island were evaluated for recovery of by-product iron and copper. Magnetic separation produced commercial-grade magnetite concentrates containing 63 percent iron and iron recoveries of 90 to 94 percent. The copper mineral chalcopyrite was recoverable by conventional froth flotation. Two other samples from Prince of Wales Island were studied for amenability of gold and silver recovery by cyanidation.

\section{BUREAU OF LAND MANAGEMENT}

In the 1993 assessment year (September 1992 to September 1993), there were filings/recordings on a total of 11,212 Federal mining claims in Alaska. The rental fee was paid on 9,779 claims, and Small Miner Exemptions were filed on 1,433 claims. The number of active operations on BLM-administered land included 153 Notices and 97 Plans of Operations. Decisions will be issued resulting in the closure of 9,771 claims. Four mineral patent applications were adjudicated to completion, and 2 mineral patents covering 18 claims were issued. One mineral patent application covering two claims was rejected.

\section{NATIONAL PARK SERVICE}

The papers listed in the following sections on NPS minerals activities and research are catalogued in appendix 1 , NPS section.

\section{MINING CLAIM ACTIVITIES}

Mining Plans of Operation.-In Bering Land Bridge National Preserve, one mining Plan of Operations is currently under environmental review. In Denali NP\&P, the NPS initiated review on one new proposed Plan of Operations, completed environmental review on a second plan, and continued boundary definition work on a third plan. No active mining occurred in Denali NP\&P in 1993. In Kenai Fjords National Park, one proposed Plan of Operations was submitted for review. Two mining operations were active in Wrangell-St. Elias NP\&P, but no new plans were received for that unit. No other mining occurred in Alaskan park units during 1993.

Mineral validity examinations.-The NPS mineral validity program determines the validity of all unpatented Federal mining claims in Alaska park units. Validity determination is a necessary component of mining plan review and acquisition. In 1993, NPS mineral examiners completed 63 field examinations for all remaining placer claims and most of the remaining lode claims in Denali NP\&P. Mineral reports for these examinations should be completed within 2 years. In 1993, the BLM approved 1 NPS Denali mineral report and was in the process of reviewing or revising 3 others; another 3 reports are in final draft form, and 16 reports are in progress.

There were 916 administratively active Federal mining claims in Alaska park units prior to the August 31, 1993, rental fee deadline. Rental fees were not paid on approximately 35 percent of these claims.

Mining claim acquisition.-Since 1991, Congress has appropriated $\$ 11.8$ million for mining claim acquisition in Denali NP\&P. During 1993, hazardous-waste-survey recertifications were completed for 7 patented and 16 
unpatented mining properties, and inspections for real estate appraisal were completed on 3 patented and 7 unpatented properties. Offers were made for five properties in the Kantishna Hills area, and two purchases were completed. A bid tour was conducted to obtain estimates for the relocation of personal property from seven mining properties. One owner of a patented property relocated his personal property and was reimbursed for his expenses under the authority of the Uniform Relocation Assistance and Real Property Acquisition Policies Act.

\section{ABANDONED MINERAL LANDS RECLAMATION}

Within the NPS, abandoned mineral lands are managed under a multiphase Mineral Land Restoration (MLR) program, which consists of eight major components: (1) Inventory, (2) Explosives Removal, (3) Hazard Signing and Reduction, (4) Hazardous Material Removals; (5) Debris Removals, (6) Tailing and Acid Mine Drainage Remediations, (7) Recontouring and Revegetation, and (8) Floodplain Restoration. The MLR program is designed to eliminate or mitigate health and safety hazards, preserve significant cultural features, and re-establish natural environmental processes on NPS lands. In 1993, MLR activities took place in four park units.

Denali NP\&P.-Cleanup activities on seven former or inactive mining sites were completed. Items removed from the park included 300 large fuel drums, 55 lead-acid batteries, 7,570 liters of waste fuels and oils, 6.5 metric tons of garbage, 3 wrecked pickup trucks, a large washplant, and a flatbed trailer. In addition, over 16.9 metric tons of scrap steel was shipped for recycling, and 61 cubic meters of scrap plywood and lumber was burned.

Glacier Bay National Park.-One former hard-rock mine site was cleaned. Six-and-one-half metric tons of steel and four cubic meters of garbage were removed from the site, and several cubic meters of scrap lumber was burned. Concrete was transported to the site in preparation for adit closure and hazardous fluid removal work in 1994.

Wrangell-St. Elias NP\&P.-An old all-terrain vehicle, 37 large fuel drums, 49 smaller containers, and 0.04 cubic meters of contaminated soil were removed from 4 sites. At the Kennecott mill complex, the Kennecott Corporation extracted asbestos from plumbing and electrical equipment in buildings and heating-system utilidors. Approximately 38 cubic meters of asbestos was removed.

Yukon-Charley Rivers National Preserve.-An investigation was completed at the Coal Creek site, a former floating bucket line dredge operation. The ACE is managing this investigation under an Interagency Agreement with the NPS. Following the initial site examination, a field sampling program was instituted to detect possible mercury and petroleum contamination. Over 200 soil, sediment, and water samples were analyzed using immuno- assay-absorbent test kits; this new technology produces on-site analytical results, thereby allowing field screening of sample localities.

\section{RECLAMATION RESEARCH}

During 1993, the NPS completed its fiftl year of reclamation studies on an abandoned placer mine on Glen Creek in the Kantishna Hills of Denali NP\&P. Studies have focused on the techniques of tailings stabilization, flood-plain and stream-channel design and stabilization, and revegetation. In 1993, data were collected tc evaluate the performance of reconstructed flood plains and the revegetation program.

Hydraulic capacity and shear-stress equations were applied to determine stream and flood-plain geometries for Glen Creek's reconstruction. The design employed incorporated a 1.5-year (bankfull) stream-channel capacity and a 100-year flood-plain discharge capacity. Single stream channels were established in areas of unnatural braided flow, and flood plains were broadened to reduce cut-bank erosion and to provide the proper topography for natural flood-plain processes. Storm events in 1992 and 1993 provided performance data on channel design, stal lity, and flood-plain erosion. Successful performance d ring the storm events was due, in large part, to manmade brush bars that were constructed by anchoring horizortal aldersapling bundles in the stream bed perpendicular to the channels; these artificial bars facilitated sediment deposition and stabilized the newly constructed flood plain (Karle and Densmore, 1994).

The success of natural revegetation varied in accordance with water and soil availability (Densmore, 1994). In areas where groundwater or respread overburden provided adequate moisture and proper seed-bed conditiors, natural revegetation was relatively rapid, and supplemental plantings, seeding, or fertilization did not significartly speed succession. In areas of reshaped, coarse placer tailings that contained little organic material, natural revegetation was poor and had low species diversity. On these sites, supplemental actions were necessary to match the higher natural revegetation rates of the more propitious sites. One supplemental action evolved from a study on alder growth, which showed that hand-planted alder seedlings performed well on sites with poor seed beds. Establishment of these alders improved seeding conditions, which then enabled willows and spruce to root and establish themselves. Natural revegetation and subsequent succession on pcor-quality sites was much slower in areas where alders hac not been transplanted.

In the fall of 1993, a report was preparec to document the costs of certain phases of the project. Within the 0.11-square-kilometer project area, 91 metric tons of debris was removed and 91,747 cubic meters $c^{f}$ tailings 
was recontoured at a cost of $\$ 78,000$; greenhouse-propagated alder seedlings were hand-planted in selected areas at a cost of $\$ 5,000$; and the channel and flood plain were reconstructed at a cost of $\$ 77,000$. Total project costs ran $\$ 440,000$. Costs for other sites would be dependent upon reclamation objectives, ease of access, preplanning during the active mining phase, and environmental conditions.

\section{OTHER ACTIVITIES}

AMRAP authorizations.-As mandated in Section 1010(b) of ANILCA, the NPS has regulations to control AMRAP activities within park units. During 1993, eight AMRAP projects were approved in seven park units. The USGS worked in Gates of the Arctic NP\&P and Noatak National Preserve, Kenai Fjords National Park, and Lake Clark NP\&P; the USBM conducted studies in Glacier Bay NP\&P, Gates of the Arctic NP\&P, and Wrangell-St.Elias NP\&P; and the MMS operated in Katmai NP\&P and Lake Clark NP\&P.

Cultural resources mining inventory.-The Cultural Resources Mining Inventory and Monitoring Program continued to ensure that all mining-related activities in Alaska's national parks are in full compliance with Federal historic and cultural resource protection laws and regulations. Field crews conducted surveys in Denali NP\&P, Gates of the Arctic NP\&P, Glacier Bay NP\&P, WrangellSt. Elias NP\&P, and Yukon-Charley Rivers National Preserve; 30 historic mining sites were documented.

One site recorded in the Bremner River valley may be the oldest placer-mining site in Wrangell-St. Elias NP\&P. The area was first prospected in 1901, and mining began in 1902. Elaborate hand-piled stone walls attest to the labor-intensive mining methods employed at the turn of the century. Several well-preserved 1930's-era lode mines located in the vicinity were also examined.

Land surveys.-The NPS conducts land surveys to determine the locations of unpatented mining claims and claim boundaries within park units. In 1993, the NPS conducted surveys on 39 claims in Denali NP\&P and on 6 claims in Wrangell-St. Elias NP\&P. Computer-generated topographic maps for those claims were produced by the NPS at a scale of 1:1,200 and a contour interval of 61 meters. The NPS also contracted a cadastral survey of the Kennecott mines area. The contractor produced over 30 sheets at a scale of 1:2,400. The maps are currently used for numerous projects related to minerals and resource management and claim acquisition, including validity examinations, review and analysis of Plans of Operation, hazardous waste surveys, reclamation projects, and property appraisals.

The NPS also produced approximately 3,000 individual computer-generated cartographic, graphic, and engineering products in support of its management programs. Over 25 percent of those products was supplied to the pri- vate sector, including mining claimants, consultants, concessionaires, and other interested parties. The NPS land survey section also contracted for complete arrial photographic coverage of the Klondike Gold Rush National Historic Park.

\section{U.S. FISH AND WILDLIFE SERVICE}

Valid mining claims on lands established as national wildlife refuges by the ANILCA in 1980 remain valid if they are kept active. In 1993, there were 127 claims on 8 of the 16 refuges in Alaska: 70 claims in the Alaska Peninsula NWR, 2 in the Arctic NWR, 1 in the Becharof NWR, 2 in the Innoko NWR, 4 in the Tetlin I'WR, 35 in the Togiak NWR, and 13 in the Yukon Delta NWR. A mill-site claim and six placer claims in the A rctic NWR were recently disallowed by the BLM for non sonforming uses of a mining claim, lack of activity, and failure to pay filing fees; the disallowance, which is subject to appeal, was the result of a request to the claimant to either relinquish the claims or prove their validity.

The FWS prepared reports of contaminant monitoring on the Innoko, Koyukuk, Nowitna, and Sela vik National Wildlife Refuges where placer mining occu's upstream of the refuges, but did no fieldwork in 1993. Th" FWS also reviewed 21 ACE permits or permit modificatic ns for mining-related activities. The FWS monitored the Greens Creek silver mine and participated in investigations, planning, and permit review of the proposed A-J ard Kensington gold mines in Juneau and Berners Bay, respectively.

Togiak NWR issued a special-use permit to Utah State University's Department of Geology to conduct research on glacier fluctuations and sea level changes in northeastern Bristol Bay. Small sediment and organic material samples were collected from 100,000-year-old deposits. The samples will be analyzed to describs the nature of the sediments and their stratigraphic succession.

\section{U.S. FOREST SERVICE}

The USFS oversees minerals exploration and development on 93,000 square kilometers of National Forest lands in 14 Ranger Districts in Alaska (table 1). Mineralsrelated work in national forests requires USFS authorization via approved Notices of Intent or approvad Plans of Operation. There was a marked increase in the number of requests filed with the USFS in 1993: 51 Notises and 76 Plans, up from 29 Notices and 64 Plans in 1992. Most of the increase is attributed to the greater number of locators seeking to qualify for the small-miner exemption from the annual \$100-per-claim filing fee. This exemption waives the filing fee for persons with 10 or fewer mining claims in exchange for annual assessment work on the claims; an affidavit of work documents the required assessment work. 
MINERALS DEVELOPMENT IN TONGASS NATIONAL FOREST

Admiralty Island National Monument.-Although Greens Creek was the largest producing silver mine in the United States, low metals prices forced closure of the mine in April 1993; no definite plans for resuming operations have been announced. However, in anticipation of higher prices, Kennecott Greens Creek Mining has installed a new telecommunications system, has completed the construction of a wastewater treatment facility, and is performing underground development work. The USFS has approved an additional waste-rock storage site at the mine.

Juneau Ranger District.-The final EIS has been completed for the Kensington gold project, which continues to await permit issuance by a variety of government agencies. The Jualin gold project's claims lie adjacent to the Kensington claims, and both projects are exploring the geologic structure known as the Jualin Shear Zone. Couer d'Alene Mines purchased a two-thirds interest in Curator American's lease on the Jualin project. Current mineral exploration has been active since 1980; gold was originally discovered on the property in 1895 .

The USFS cooperated with the BLM in the preparation of the EIS for the A-J project, located near downtown Juneau. In the project's final EIS, Sheep Creek was identified as the preferred alternative for tailings disposal. A lawsuit has been filed by an environmental coalition to prevent the exemption of the proposed tailings dam from regulation by the Clean Water Act (Juneau Empire, December 21, 1993). If the Sheep Creek site selection is eventually overruled in court, the new preferred alternative might be one of three sites located on National Forest lands. The USFS would then have to approve the selection before any tailings disposal could occur; approval would be extended through a Plan of Operations or a special-use permit.

\section{MINERAL PATENTS}

Admiralty Island National Monument.-The Pyrola Partnership application involves four lode claims at Pyrola, a barite-bearing lead-zinc-silver massive-sulfide deposit on Admiralty Island. The field examination on this case was conducted in July 1993, and completion of the report is expected in July 1994.

Juneau Ranger District. - The Tracy Partnership applied for patent on three lode claims at the Tracy zinccopper-silver deposit (fig. 19), located in the Tracy ArmFords Terror Wilderness Area. The mineral report on this case is nearing completion.

Thorne Bay Ranger District.-The Newman application sought patent for 2 millsite claims and 11 lode claims covering the Poorman magnetite-copper-gold deposit on the Kasaan Peninsula, Prince of Wales Island. The USFS mineral report, completed in September 1993, recommended patent approval for only two of the lode claims, rejecting the remaining lode claims and millsites.

\section{EXPLORATION ON NATIONAL FOREST LANDS}

Craig Ranger District.-Exploration continues for various metals in this area: base-metal volcanogenic massive sulfides at Trocadero Bay, copper and zinc on the Ruby Tuesday claims in Cholmondeley Sound, zinc-copper-lead at the Lucky Nell Mine, and gold on Lancaster Peninsula. Red Dotson continues to maintain mining claims at the Bokan Mountain uranium and rare-earth deposits (fig. 10).

Hoonah Ranger District.-Assessment work on the Apex-El Nido gold property across Lisianski Inlet from Pelican consisted of surveying boundaries and access road alignment. Hyak Mining searched for gold on the east side of Chichagof Island in the vicinity of East Point.

Juneau Ranger District.-Echo Bay carried out limited surface drilling and sampling at the Kensington gold mine, while Kennecott performed helicopter-supported surface drilling in the Gold Fork area south of Juneau. Limited sampling and assessment work was done at the Alaska Empire gold property on Admiralty Island's Mansfield Peninsula.

Misty Fjords National Monument.-The development of the Quartz Hill molybdenum deposit, purchased several years ago by Cominco, remains in hiatus; a ruling on the appeal filed by the Sierra Club Legal Defense Fund on behalf of a variety of environmental and commercial fishing organizations awaits a decision by the Chief of the Forest Service.

Sitka Ranger District.-Activities include gold prospecting near the head of Silver Bay and jade exploration in the vicinity of Blue Lake.

Yakutat Ranger District.-Assessment work was conducted on two placer gold mining claims in the Russell Fjord Wilderness.

Ketchikan Mining District.-The USBM completed their fieldwork for the Ketchikan Mining District study, which spreads out over several USFS ranger districts in southeastern Alaska. This study, together with USGS AMRAP work, should, when completed, spur mineral exploration activity on Prince of Wales Island. In addition to having a substantial mineral endowment, Price of Wales Island is an attractive exploration target because it has an established infrastructure.

\section{INDUSTRIAL MINERALS}

\section{OVERVIEW OF INDUSTRY ACTIVITY}

Production of sand, gravel, and building stone has remained at fairly constant levels for the past 7 years, both in value and quantity. In 1993, 12.3 million metric tons of sand and gravel was valued at $\$ 39.65$ million, and 3.1 million metric tons of building stone was valued at $\$ 24.7 \mathrm{mil}-$ lion (table 6). The value of jade and soapstone fluctuates yearly due to the varying quantities of raw and processed materials sold. 


\section{ACTIVITY BY FEDERAL AGENCIES}

\section{U.S. GEOLOGICAL SURVEY}

Seven barite deposits were discovered by the USGS and USBM in the central part of the Howard Pass quadrangle during the 1990, 1991, and 1992 field mapping seasons (Kelley and others, 1993). The USBM estimates that there is about 45 million metric tons of barite in these deposits, which increases known domestic reserves of this commodity by 50 percent. Development of this resource for use as a drilling-mud component could provide a closer and cheaper supply of this material for North Slope oil fields than the present barite sources in Nevada.

\section{U.S. BUREAU OF MINES}

The Ketchikan Mining District contains high-purity limestone and significant gravel resources. The USBM ex-

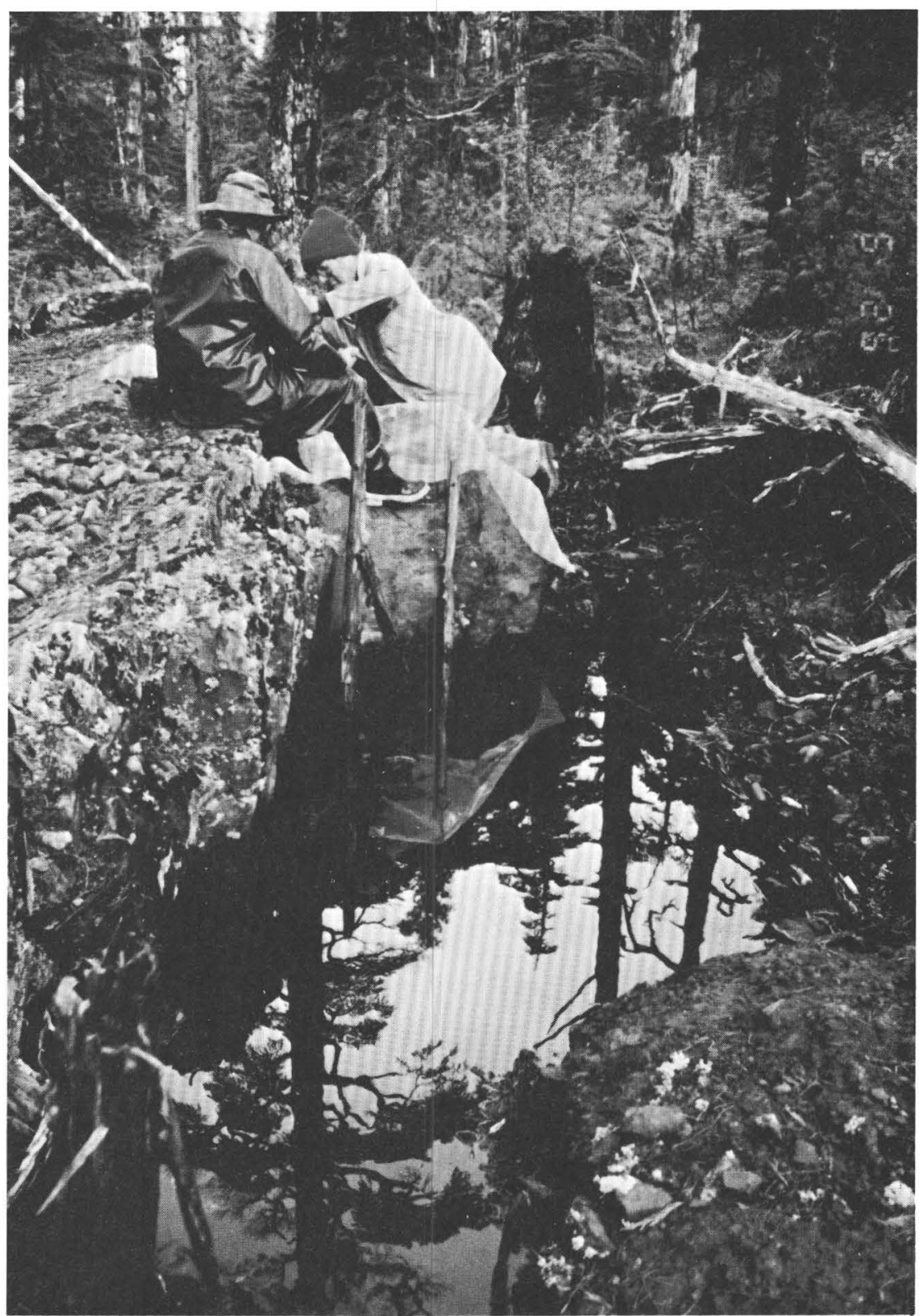

Figure 19. USFS mineral examiner and geologist sample collar of shaft at the Tracy claim block for the Tracy Partnership mineral patent application, Tracy Arm-Fords Terror Wilderness, Tongass National Forest, southeastern Alaska. Photograph by G. Grove. 
amined and sampled these industrial minerals as part of their studies in the district. In the Colville Mining District, the ADGGS cooperated with the USBM in compiling and generating maps of industrial mineral localities.

\section{BUREAU OF LAND MANAGEMENT}

By the end of fiscal 1993, the BLM had made 48 sand and gravel sales.

\section{U.S. FISH AND WILDLIFE SERVICE}

When compatible with refuge purposes, the FWS issues special-use permits for the sale and extraction of sand and gravel to support development activities in rural communities. In 1993, Izembek NWR sold gravel at Cold Bay and False Pass, and Yukon Delta NWR sold gravel in the Kuskokwim River near Bethel. The Aleutian Islands Unit, Alaska Maritime NWR, is processing an application for a gravel sale at Atka.

\section{U.S. FOREST SERVICE}

The USFS annually issues permits for the removal of many thousands of tons of sand, gravel, and stone from National Forest lands. Much of this material is used in the construction of timber-sales roads. Lesser amounts are used by State and local governments for the construction and maintenance of breakwaters, airports, and roads.

Approximately 765,000 cubic meters of sand, gravel, and shot rock was sold from the Chugach National Forest in 1993; one-quarter of this material was extracted and used for road construction on Montague Island in Prince William Sound. Large reserves of generally high-quality sand and gravel exist in Portage Valley, 80 kilometers southeast of Anchorage. This material, administered by the Glacier Ranger District, serves as a primary source for aggregate in the Girdwood area. The Portage Valley gravelextraction sites are reclaimed mainly for fish enhancement.

\section{REFERENCES CITED}

Alaska Business Monthly [published monthly by Alaska Business Publishing Company, Box 241288, Anchorage, AK 99524-1288].

Alaska Journal of Commerce [published weekly by OCA Publishing, 3710 Woodland Drive, Suite 2100, Anchorage, AK 99517].

Alaska Maritime National Wildlife Refuge, 1993, Environmental assessment of the proposed radioactive soil removal from the Project Chariot site at Cape Thompson: U.S. Fish and Wildlife Service, 37 p., plus appendixes.
Alaska Oil and Gas Conservation Commission Bulletin [published monthly by the State of Alaska, Alaska $C: 1$ and Gas Conservation Commission, 3001 Porcupine Drive, Anchorage, AK 99501].

Alaska Report [published weekly by Petroleum Information Corporation, P.O. Box 2612, Denver, CO 80201-2612].

American Society for Testing and Materials, 1980, S andard for metric practice: Philadelphia, Pennsylvania, American Society for Testing and Materials, E380-79 [PCN 06-50380741], 42 p.

Anchorage Daily News [published daily by Anchorage Daily News Incorporated, 1001 Northway Drive, Ancl orage, AK 99508].

Bundtzen, T.K., Swainbank, R.C., Clough, A.H., Henring, M.W., and Hansen, E.W., 1994, Alaska's mineral industry 1993Summary: Alaska Division of Geological and Geophysical Surveys, Information Circular 39, 11 p.

Callahan, J.E., Denton, S.W., and Imm, T.A., 1993, Western Arctic coal: Alaska Miner, v. 21, no. 3, p. 10, 11, 17, 19.

Chenowith, W.L., 1993, Uranium: unpublished manuscript.

Clough, J.G., Patton, P.C., and Christiansen, A.C., eds., 1987, Arctic National Wildlife Refuge, Alaska, coastal plain resource assessment-Report and recommendation to the Congress of the United States and final legislative Environmental Impact Statement: Washington, DC, U.S. Fish and Wildlife Service, U.S. Geological Survey, and Bureau of Land Management, 2 volumes, $208 \mathrm{p}$.

Coal News [published weekly by National Coal Association, 1130 17th Street N.W., Washington DC 20036].

Fairbanks Daily News-Miner [published 6 days a week by the Fairbanks Publishing Company, 200 North Cushman, Fairbanks, AK 99701].

Glenn, R., and Allen, W.W., 1992, Geology, reservoir engineering, and methane-hydrate potential of the Walakpa gas field, North Slope, Alaska: Department of Energy/Morgantown Energy Technology Center, DOE/MC/28131-3334 (NTIS DE93000271), $26 \mathrm{p}$.

Juneau Empire [published 6 days a week by Southeastern Newspapers Corporation, 3100 Channel Drive, Juneau, AK 99801-7814].

Kelley, J.S., Tailleur, I.L., Morin, R.L., Reed, K.M., Harris, A.G., Schmidt, J.M., Brown, F.M., and Kurtak, J.M., 1993, Barite deposits in the Howard Pass quadrangle and possible relations to barite elsewhere in the northwestern Brooks Range, Alaska: U.S. Geological Survey Open-File Report 93-215.

Kirschner, C.E., 1988, Map showing sedimentary basins of onshore and continental shelf areas, Alaska: U.S. Geological Survey Miscellaneous Investigations Series Map I-1873, one sheet, scale 1:2,500,000.

Leonard, K.R., and Huber, D.F., 1987, Status of Alaska Mineral Resources Data System, in Hamilton, T.D., and Galloway, J.P., eds., Geologic studies in Alaska by the U.S. Geological Survey during 1986: U.S. Geological Survey Circular 998, p. 15-18.

McCabe, T.R., B. Griffith, N.E. Walsh, and D.D. Young, eds., 1992, Terrestrial research-1002 area, Arctic National Wildlife Refuge, Interim Report 1988-1990: Anchorage, Alaska, U.S. Fish and Wildlife Service, 432 p.

Mining Journal [published weekly by The Mining Journ?l Limited, 60 Worship Street, London EC2A 2HD, United Kin đdom]. 
Motyka, R.J., Nye, C.J., Turner, D.L., and Liss, S.A., 1993, The Geyser Bight geothermal area, Umnak Island, Alaska: Geothermics, v. 22, p. 301-327.

Northern Miner [published weekly by Northern Miner Press Limited, 7 Labatt Avenue, Toronto, Ontario, M5A 3P2, Canada].

Odell, R.D., 1993, North American uranium activity, in Rocky Mountain Scout: Casper, Wyoming, R.D. Odell, 24 p.

Oil and Gas Journal, 1993a, Big equipment sealift headed for Alaskan N. Slope: Oil and Gas Journal, v. 91, no. 30, p. 40.

1993b, TAPS to draw closer government scrutiny: Oil and Gas Journal, v. 91 , no. 30, p. 32-35.

Pittsburgh Energy Technology Center, 1993, Final Environmental Impact Statement for the proposed Healy Clean Coal Project: Pittsburgh Energy Technology Center, DOE/EIS-0186, 1100 p.

Pool, T.C., 1991, Uranium: Engineering and Mining Journal, v. 192 , no. 3 , p. $57-60$.

1994, Uranium: Engineering and Mining Journal, v. 195, no. 3 , p. 60-63.

Rintoul, Bill, 1993, Alaska drilling and production: Pacific Oil World, v. 85 , no. 1 , p. 52-57.

Schneider, J.L., ed., 1993, 1993 annual report on Alaska's mineral resources: U.S. Geological Survey Circular 1102, 70 p.

Stricker, G.D., 1991, Economic Alaskan coal deposits, in Gluskoter, H.J., Rice, D.D., and Taylor, R.B., eds., Economic Geology-U.S., v. P-2 of Geology of North America: Boulder, Colorado, Geological Society of America, Decade of North American Geology series, p. 591-602.

Weast, R.C., ed., 1974, Handbook of chemistry and physics, 55th edition: Cleveland, Ohio, CRC Press, 2,279 p.

Wells, Ken, compiler, 1992, The Kensington gold project, southeast Alaska: Alaska Geology, v. 21, no. 8, p. 1, 7.

\section{APPENDIX 1.-ALASKA MINERAL REPORTS RELEASED DURING 1993 AND EARLY 1994}

The following selected publications contain pertinent information about energy resources and other minerals in Alaska released during 1993 or early 1994; these are in addition to the reports listed in the "References Cited" section. This listing is only a selection of relevant reports from the publications of any agency. Reports by Federal or State agencies can generally be obtained from the agency offices in Alaska, or are available at the Alaska Resources Library, Federal Building, $701 \mathrm{C}$ Street, Anchorage, AK 99513-7599.

The USGS publishes a monthly listing of its own releases, "New Publications of the U.S. Geological Survey," available free from the U.S. Geological Survey, 582 National Center, Reston, VA 22092. These listings are also compiled into an annual volume, "Publications of the U.S. Geological Survey, 1993." Information about the prices and sources of listed reports is given in these two publications and is also available from the USGS Earth Science Information Centers.

The USBM's central distribution office is the Branch of Production and Distribution, 4800 Forbes Avenue, Pittsburgh, PA 15213. Many USBM reports are available from the U.S. Government Printing Office in Washington, D.C., or from the National Technical Information Service (NTIS) in Springfield, VA 22161.
USBM reports listed here are available from the USBM library in Juneau; for further information, contact the Chief, Alaska Field Operations Center, $3301 \mathrm{C}$ Street, Suite 525, Anchorage, AK 99503.

MMS publications may also be purchased from NTIS, which issues listings of all available MMS volumss. A limited number of complimentary reports are available at th MMS Public Information Office, Alaska OCS Region, Mine-als Management Service, 949 East 36th Avenue, Room 603, Archorage, AK 99508-4302; phone (907) 271-6070.

\section{DEPARTMENT OF THE INTERICR}

\section{U.S. GEOLOGICAL SURVEY}

List includes Federal and non-Federal publications by USGS authors:

Attanasi, E.D., Bird, K.J., and Mast, R.F., 1993, Eronomics and the National Oil and Gas Assessment-The case of onshore northern Alaska: American Association of Petroleum Geologists Bulletin, v. 77, no. 3, p. 491-504.

Beaudoin, B.C., Christensen, N.I., Lutter, W.J., Money, W.D., Moore, T.E., and Nokleberg, W.J., 1993, TACT refraction/ wide angle reflection profiling of the Yukon-Tanana Uplands, east-central Alaska [abs.]: Geological Society of America Abstracts with Programs, v. 25, no. 2, p. 8.

Belkin, H.E., and Sparck, H.M., 1993, Mercury, arsenic, antimony, and selenium contents of sediment from the Kuskokwim River, Bethel, Alaska, USA: Environmental Geology, v. 22, no. 2, p. 106-110.

Box, S.E., Moll-Stalcup, E.J., Frost, T.P., and Murphy, J.M., 1993, Preliminary geologic map of the Bethel and southern Russian Mission quadrangles, southwestern Alaska: U.S. Geological Survey Miscellaneous Field Studies Map MF2226-A, 20 p., 1 sheet, scale 1:250,000.

Brew, D.A., 1993, Bedrock-geologic and geophysic?l research in Glacier Bay National Park and Preserve-Unique opportunities of local to global significance [abs.]: Glacie- Bay Science Symposium, Third, Gustavus, Alaska, Septenber 15-18, 1993, Program and Abstracts, unpaged. [U.S. National Park Service and Friends of Glacier Bay, Box 135, Gustavus, AK 99826].

1993, Regional geologic setting of mineral resources in southeastern Alaska, in Godwin, L.H., and Smith, B.D., eds., Economic mineral resources of the Annette Islands Reserve, Alaska: U.S. Department of the Interior, Bureau of Indian Affairs, Division of Energy and Mineral Resol'res publications, p. 13-20.

Brew, D.A., and Ford, A.B., 1993, Regional distribution and geologic context of volcanic-rock-hosted massive-sulfide deposits in southeastern Alaska and adjacent parts of British Columbia [abs.]: Alaska Miner's Association, Conference Juneau 1993, Juneau, Alaska, April 21-23, 1S93, Abstracts of Professional Papers, p. 33-34.

1993, Regional distribution and geologic context of volcanic-rock-hosted massive-sulfide deposits in southeastern Alaska and adjacent parts of British Columbia [abs.]: Alaska Miner, v. 21, no. 8, p. 11. 
Bultman, M.W., Force, E.R., Gettings, M.E., and Fisher, F.S., 1993, Comments on the "three-step" method for quantification of undiscovered mineral resources: U.S. Geological Survey Open-File Report 93-23, 59 p.

Bundtzen, T.K., Miller, M.L., Goryachev, N.A., and Nokleberg, W.J., 1993, Late Cretaceous and early Tertiary igneous-related metallogenic belts, Russian Northeast and western Alaska [abs.]: Northwest Mining Association Annual Meeting, Abstracts, p. 28.

Cathrall, J.B., Arbogast, B.F., VanTrump, G., Jr., and McDanal, S.K., 1993, Geochemical maps showing the distribution of selected elements in stream-sediment samples from the Craig, Dixon Entrance, and western edges of the Ketchikan and Prince Rupert quadrangles, southeast Alaska: U.S. Geological Survey Miscellaneous Field Studies Map MF-2217-A, 2 sheets, scale 1:250,000.

Cathrall, J.B., McDanal, S.K., VanTrump, G., Jr., Arbogast, B.F., and Grybeck, D., 1993, Geochemical maps showing the distribution and concentration of selected elements in nonmagnetic heavy-mineral-concentrate samples from stream sediment from the Craig, Dixon Entrance, and western edges of the Ketchikan and Prince Rupert quadrangles, southeast Alaska: U.S. Geological Survey Miscellaneous Field Studies Map MF-2217-B, 2 sheets, scale 1:250,000.

Cole, F., Bird, K.J., and Howell, D.G., 1994, Preliminary results of a tectonic subsidence analysis of the central North Slope, Alaska, in Till, A., and Moore, T.E., eds., Geologic studies in Alaska by the U. S. Geological Survey, 1993: U.S. Geological Survey Bulletin [in press].

Collett, T.S., 1993a, Natural gas hydrates of the Prudhoe Bay and Kuparuk River area, North Slope, Alaska: American Association of Petroleum Geologists Bulletin, v. 77, no. 5, p. 793-812.

1993b, Natural gas production from Arctic gas hydrates, in Howell, D.G., ed., The future of energy gases: U.S. Geological Survey Professional Paper 1570, p. 299-312.

1993c, Natural gas production from Arctic gas hydrates [abs.]: American Association of Petroleum Geologists Bulletin, v. 77 , no. 9 , p. 1614 .

1993d, Geochemistry of natural gas hydrates [abs.]: American Chemical Society National Meeting, Chicago, Illinois, August 22-27, 1993, Abstracts of Papers, Part 1, Abstract Number 81.

Collett, T.S., and Bird, K.J., 1993a, Unfrozen, high-salinity intervals within ice-bearing permafrost, North Slope of Alaska: 6th International Conference on Permafrost, Beijing, China, July 5-9, 1993, Offprint v. 1, p. 94-99.

1993b, Gas hydrate surface-simulating seismic reflector in the Prudhoe Bay-Kuparuk River region of northern Alaska [abs.]: American Association of Petroleum Geologists Annual Meeting, New Orleans, Louisiana, April 25-28, 1993, Proceedings, p. 87.

Collett, T.S., Bird, K.J., and Magoon, L.B., 1993, Subsurface temperatures and geothermal gradients on the North Slope of Alaska: Cold Regions Science and Technology, v. 21, p. 275-293.

Collett, T.S., and Cunningham, K.I., 1993, Natural gas hydratesA source of atmospheric methane [abs.]: Eos (Transactions of American Geophysical Union), v. 74, no. 43, p. 151-152.

Collett, T.S., and Kvenvolden, K.A., 1993a, Interrelations between gas hydrates of northern Alaska and atmospheric meth- ane [abs.], in Kelmelis, J.A., and Snow, K.M., eds., Proceedings of the U.S. Geological Survey global change research forum, Herndon, Virginia, March 18-20, 1991: U.S. Geological Survey Circular 1086, p. 77-78.

-1993b, The significance of natural gas hyd ates at the MacKenzie Delta drill site: The Nasen Icebreaker (Nasen Arctic Drilling Program Newsletter), no. 4, p. 1-8.

Crock, J.G., Beck, K.A., Fey, D.L., Hageman, P.L., Papp, C.S., and Peacock, T.R., 1993, Element concentratiors and baselines for moss, lichen, spruce, and surface soils, in and near Wrangell-Saint Elias National Park and Preserve, Alaska: U.S. Geological Survey Open-File Report 93-14, 98 p.

Crovelli, R.A., 1993, Probability and statistics for petroleum resource assessment: U.S. Geological Survey Ofen-File Report 93-582, $143 \mathrm{p}$.

Csejtey, Béla, Jr., Keith, W.J., Saltus, W.R., Morir, R.L., and Gray, J.E., 1993, Preassessment of the Holy Cross quadrange, west-central Alaska [abs.]: Geological Society of America, Abstracts with Programs, v. 25, no. 5, p. 25.

Dolton, G.L., Bird, K.J., Varnes, K.L., and Gautier, D.L., 1993, Onshore oil and gas resource assessment are?s-Alaska, 1993: U.S. Geological Survey Open-File Report 93-331, 1 sheet, scale 1:5,000,000.

Dusel-Bacon, Cynthia, and Till, A.B., 1993, Geologir studies in Alaska by the U.S. Geological Survey, 1992: U.S. Geological Survey Bulletin 2068, 250 p.

Eppinger, R.G., 1993, Gold and cinnabar in heavy-mineral concentrates from stream-sediment samples collected from the western half of the Lime Hills $1^{\circ} \times 3^{\circ}$ quadrangle, Alaska, in Dusel-Bacon, Cynthia, and Till, A.B., eds., Geologic studies in Alaska by the U.S. Geological Survey, 1992: U.S. Geological Survey Bulletin 2068, p. 91-100.

Flores, R.M., and Stricker, G.D., 1993, Early Cenozoic depositional systems, Wishbone Hill District, Matanuska Coal Field, Alaska in Dusel-Bacon, Cynthia, and Till, A.B., eds., Geologic studies in Alaska by the U.S. Geological Survey, 1992: U.S. Geological Survey Bulletin 2068, p. 101-117.

1993, Reservoir framework architecture in the Clamgulchian type section (Pliocene) of the Sterling Formation, Kenai Peninsula, Alaska in Dusel-Bacon, Cynthia, and Till, A.B., eds., Geologic studies in Alaska by the U.S. Geological Survey, 1992: U.S. Geological Survey Bulletin 2068, p. 118-129.

1994a, Interfluve-channel facies models in the Miocene Beluga Formation near Homer, south Kenai Peninsula, Alaska in Rao P.D., Focus on Alaska's coals '93: Fairbanks, Alaska, Mineral Industry Research Laboratory Report [in press]. 1994b, Responses of coal splitting and associated drainage pattern to syntectonism in the Paleocene and Eocene Chickaloon Formation, Matanuska Coal Field, Alaska in Rao P.D., Focus on Alaska's coals '93: Fairbarks, Alaska, Mineral Industry Research Laboratory Report [in press].

Flores, R.M., Stricker, G.D., and Roberts, S.B., 1991, Miocene coal-bearing strata of the Tyonek Formation-Braided stream deposits in the Chuit Creek-Chuitna River drainage basin, southern Alaska in Till, A.B., and Moore, T.E., Geologic studies in Alaska by the U.S. Geological Strvey, 1993: U.S. Geological Survey Bulletin [in press].

Ford, A.B., and Brew, D.A., 1993, Geochemical characteristics of Triassic and upper Paleozoic metavolcanic rocks of Wrangellia 
in northern southeastern Alaska, in Dusel-Bacon, Cynthia, and Till, A.B., eds., Geologic studies in Alaska by the U.S. Geological Survey in 1992: U.S. Geological Survey Bulletin 2068, p. 197-217.

Ford, R.C., and Snee, L.W., 1993, Age and structural setting of gold-bearing veins, Bluff area, southern Seward Peninsula, Alaska [abs.]: Eos (Transactions of American Geophysical Union), v. 74, no. 43, p. 695.

$1993,{ }^{40} \mathrm{Ar} /{ }^{39} \mathrm{Ar}$ thermochronology of white mica from the Bluff area, Alaska-The first ages for lode sources of placer gold deposits in the Seward Peninsula [abs.]: Geological Society of America, Abstracts with Programs, v. 25, no. 6, p. A469.

Fouch, T.D., Collett, T.S., Bird, K.J., Carter, L.D., and Frederiksen, N.O., 1993, The Cretaceous and Tertiary Sagavanirktok Formation, a major exploration target under the North Slope of Alaska and adjacent Beaufort Sea-Preliminary evaluation of exposures at Franklin Bluffs [abs.]: Society for Sedimentary Geology, Rocky Mountain Section, Newsletter, v. 18 , no. 2 , p. 1-2.

Gamble, B.M., and Till, A.B., 1993, Maps showing metallic mineral resources of the Bendeleben and Solomon quadrangles, western Alaska: U.S. Geological Survey Miscellaneous Field Studies Map MF-1838-D, 22 p., 3 sheets, scale 1:250,000.

Gautier, D.L., and Varnes, K.L., 1993, Plays for assessment in Region 1, Alaska as of October 4, 1993-1995 National Assessment of Oil and Gas: U.S. Geological Survey Open-File Report 93-596-A, 8 p.

Goldfarb, R.J., and Borden, J.C., 1993, Geochemical evaluation of stream-sediment data from the Bering Glacier and Icy Bay quadrangles, south-central Alaska, in Dusel-Bacon, Cynthia, and Till, A.B., eds., Geologic studies in Alaska by the U.S. Geological Survey, 1992: U.S. Geological Survey Bulletin 2068, p. 178-186.

Goldfarb, R.J., and Snee, L.W., 1993, Tectonic setting, high-T thermal events, and gold vein formation within metamorphic rocks of the Alaskan Cordillera [abs.]: Alaska Miners Association, Conference Juneau 1993, Juneau, Alaska, April 2123, 1993, Abstracts of Professional Papers, p. 21.

Gray, J.E., Theodorakos, P.M., Bradley, L.A., and Bullock, J.H. Jr., 1993, Favorable areas for metallic mineral resources in and near the Horn Mountains, Sleetmute quadrangle, southwestern Alaska, in Dusel-Bacon, Cynthia, and Till, A.B., eds., Geologic studies in Alaska by the U.S. Geological Survey, 1992: U.S. Geological Survey Bulletin 2068, p. 79-91.

Grybeck, D.J., 1993, Status of geology in the Craig and Dixon Entrance quadrangles, southeastern Alaska [abs.]: Alaska Miners Association, Conference Juneau 1993, Juneau, Alaska, April 21-23, 1993, Abstracts of Professional Papers, p. 11.

Haeussler, P.J., and Bradley, D.C., 1993, Map and compilation of structural data from lode-gold mineral occurrences in the Chugach-Prince William terrane of southern Alaska: U.S. Geological Survey Open-File Report 93-325, 53 p., 1 sheet, scale 1:506,880.

Haeussler, P.J., and Nelson, S.W., 1993, Structural evolution of the Chugach-Prince William terrane at the hinge of the orocline in Prince William Sound, and implications for ore deposits, in Dusel-Bacon, Cynthia, and Till, A.B., eds., Geologic studies in Alaska by the U.S. Geological Survey, 1992: U.S. Geological Survey Bulletin 2068, p. 143-162.
Howe, D.L., Streveler, G.P., and Brew, D.A., 1993, Bibliography of research and exploration in the Glacier Bay region, southeastern Alaska, 1798-1992: U.S. Geological S rvey OpenFile Report 92-596, 70 p.

Johnsson, M.J., Howell, D.G., and Bird, K.J., 1993, Thermal maturity patterns in Alaska-Implications for tectonic evolution and hydrocarbon potential: American Association of Petroleum Geologists Bulletin, v. 77, no. 11, p. 1874-1903.

Johnsson, M.J., and Howell, D.G., 1993, Thermal maturity map of Alaska: U.S. Geological Survey Miscellaneo's Investigations Series Map [in press].

Karl, S.M., 1993, Map and table of mineral deposits on Annette Island, Alaska: U.S. Geological Survey Open-File Report 92-690, 57 p., 1 sheet, scale 1:63,360.

Kayen, R.E., and Lee, H.J., 1993, Slope stability in regions of sea-floor gas hydrate-Beaufort Sea continental slope: U.S. Geological Survey Bulletin 2002, p. 97-103.

Kelley, J.S., Tailleur, I.L., Morin, R.L., Reed, K.M., Harris, A.G., Schmidt, J.M., Brown, F.M., and Kurtak, J.M., 1993, Barite deposits in the Howard Pass quadrangle and possible relations to barite elsewhere in the northwestern Brooks Range, Alaska: U.S. Geological Survey Open-File Report 93-215, 13 p., 9 pls., scale 1:63,360.

Kelley, K.D., Barton, H.N., Sutley, S.J., and O'Leary, R.L., 1993, Maps showing geochemistry of sediment samples from the southern part of Chandler Lake quadrangle, Alaska: U.S. Geological Survey Miscellaneous Field Studies Map MF2144-C, 2 sheets, scale 1:250,000.

Kelley, K.D., and Sutley, S.J., 1993, Maps showing geochemistry of sediment samples from the northern part of C" andler Lake quadrangle, Alaska: U.S. Geological Survey Miscellaneous Field Studies Map MF-2144-D, 2 sheets, scale 1:250,000.

Kelley, K.D., Sutley, S.J., and Frisken, J.G., 1993, Maps showing geochemistry and mineralogy of nonmagnetic heavy-mineralconcentrate samples from the southern part of the Chandler Lake quadrangle, Alaska: U.S. Geological Survey Miscellaneous Field Studies Map MF-2144-B, 2 sheets, scale 1:250,000.

Khanchuk, A.J., Palandzjan, S.A., and Panchenko, I.V., 1994, Geologic map of ophiolite complexes and associated volcanic arc and metamorphic terranes of northeastern Russia: U.S. Geological Survey Open-File Report 92-0020H, 1 sheet, scale $1: 250,000$.

Kilburn, J.E., Goldfarb, R.J., Griscom, A., and Box, S.E., 1993, Map showing metallic mineral resource potential in the Goodnews Bay, Hagemeister Island, and Nushagak Bay $1^{\circ}$ by $3^{\circ}$ quadrangles, southwest Alaska: U.S. Geological Survey Miscellaneous Field Studies Map MF-2228, 4 sheets, scale 1:250,000.

Kistler, R.W., Newberry, R.J., and Brew, D.A., Rubidium-strontium isotopic systematics of vein minerals in the Juneau Gold Belt, Alaska, in Dusel-Bacon, Cynthia, and Till, A.B., eds., Geologic studies in Alaska by the U.S. Geologinal Survey in 1992: U.S. Geological Survey Bulletin 2068, p. 236-240.

Kvenvolden, K.A., 1993, Gas hydrates-Geologica' perspective and global change: Reviews of Geophysics, v. 31, no. 2, p. 173-187.

Kvenvolden, K.A., Carlson, P.R., Threlkeld, C.N., and Warden, A., 1993, Possible connection between two Alarkan catastrophes occurring $25 \mathrm{yr}$ apart (1964 and 1989): Geology, v. 21, no. 9, p. 813-816. 
Kvenvolden, K.A., and Collett, T.S., 1993, Permafrost and gas hydrates as possible sources of atmospheric methane at high latitudes [abs.], in Kelmelis, J.A., and Snow, K.M., eds., Proceedings of the U.S. Geological Survey Global Change Research Forum, Herndon, Virginia, March 18-20, 1991: U.S. Geological Survey Circular 1086, p. 92-93.

Kvenvolden, K.A., Collett, T.S., and Lorenson, T.D., 1993, Studies of permafrost and gas hydrates as possible sources of atmospheric methane at high latitudes, in Oremland, R.S., ed., Biogeochemistry of global change: New York, Chapman and Hall, p. 487-501.

Kvenvolden, K.A., Lilley, M.D., Lorenson, T.D., Barnes, P.W., and McLaughlin, E., 1993, The Beaufort Sea continental shelf as a seasonal source of atmospheric methane: Geophysical Research Letters, v. 20, no. 22, p. 2459-2462.

Lange, I.M., Nokleberg, W.J., Newkirk, S.R., Aleinikoff, J.N., Church, S.E., and Krouse, H.R., 1993, Devonian volcanogenic massive-sulfide deposits and occurrences, southern Yukon-Tanana terrane, eastern Alaska Range, Alaska: Economic Geology, v. 88., no. 2, p. 344-376.

Light, T.D., Moll, S.H., Bie, S.W., and Lee, G.K., 1993, Reconnaissance guidelines for gold exploration in central Alaska: Journal of Geochemical Exploration, v. 47, no. 1/3, p. 89-108.

Madden-McGuire, D.J., and Tripp, R.B., 1993, Geochemical map showing the distribution of gold in the Anchorage $1^{\circ} \times 3^{\circ}$ quadrangle, Alaska: U.S. Geological Survey Miscellaneous Field Studies Map MF-2227, 1 sheet, scale 1:250,000.

Madden-McGuire, D.J., and Winkler, G.R., 1993, 'The Alaska Mineral Resources Assessment Program-Background information to accompany mineral-resource and geologic maps of the Anchorage quadrangle, south-central Alaska: U.S. Geological Survey Circular 1094, 23 p.

Menzie, W.D., and Singer, D.A., 1993, Grade and tonnage model of porphyry $\mathrm{Cu}$ deposits in British Columbia, Canada, and Alaska, U.S.A.: U.S. Geological Survey Open-File Report 93-275, 9 p.

Miller, L.D., and Goldfarb, R.J., 1993, Tectonic development and structural control of the auriferous vein deposits in the Juneau Gold Belt, southeastern Alaska [abs.]: Alaska Miners Association, Conference Juneau 1993, Juneau, Alaska, April 21-23, 1993, Abstracts of Professional Papers, p. 19.

Miller, L.D., Goldfarb, R.J., Gehrels, G.E., and Snee, L.W., 1993, Genetic links between fluid cycling, vein formation, regional deformation, and plutonism in the Juneau Gold Belt, southeastern Alaska [abs.]: Geological Society of America, Abstracts with Programs, v. 25, no. 6, p. A78-79.

Morin, Robert L., 1994, Digital terrain in the Bethel, Russian Mission, and Goodnews Bay $1^{\circ} \times 3^{\circ}$ quadrangles, Alaska, including improved terrain for parts of these quadrangles: U.S. Geological Survey Open-File Report 93-702, 12 p., two 3$1 / 2$ " diskettes.

Murphy, J.M., Fuis, G.S., Levander, A.R., Lutter, W.J., Criley, E.E., Henrys, S.A., Asudeh, I., and Fowler, J.C., 1993, Data report for the 1990 seismic reflection/refraction experiment in the Brooks Range, Arctic Alaska: U.S. Geological Survey Open-File Report 93-0265, 131 p.

Nelson, S.W., 1993, Geology and resource assessment of the Prince William Sound area in the Chugach National Forest, Alaska [abs]: Alaska Miners Association Annual Meeting, Anchorage, Alaska, Abstracts of Professional Papers, p. 9-10.
Newberry, R.J., and Brew, D.A., 1993, The alkalic connection (?) in the Juneau Gold Belt [abs.]: Alaska Miner's Association, Conference Juneau 1993, Juneau, Alaska, April 21-23, 1993, Abstracts of Professional Papers, p. 25-26.

Nokleberg, W.J., Aleinikoff, J.N., Lange, I.M., Silva, S.R., Miyaoka, R.T., Schwab, C.E., and Zehner, R.E.. 1993, Preliminary geologic map of the Mount Hayes quad angle, eastern Alaska Range, Alaska: U.S. Geological Su“vey OpenFile Report 92-594, 39 p., 1 sheet, scale 1:250,000.

Nokleberg, W.J., Bundtzen, T.K., Grybeck, D., Koch, R.D., Eremin, R.A., Rozenblum, I.S., Siderov, A.A., Byalobzhesky, S.G., Sosunov, G.M., Shpikerman, V.I., and Gorodinsky, M.E., 1993, Metallogenesis of mainland Alaska and the Russian Northeast: U.S. Geological Survey Open-File Report 93-339, 222 pages, 6 maps, scales 1:4,000,000 and 1:10,0 ?,000.

Nokleberg, W.J., Bundtzen, T.K., Grybeck, D., Shpikerman, V.I., Eremin, R.A., and Siderov, A.A., 1993, Correlat:ons of lode metallogenic belts between the Russian Northeast and mainland Alaska [abs.]: Northwest Mining Association Abstract Booklet, p. 26.

Nokleberg, W.J., Lange, I.M., Schmidt, J.M., and Zierenberg, R.A., 1992 Metallogenesis of stratiform zinc-lead-silver and associated barite deposits, northwestern Brooks Range, in Proceedings of Circum-Pacific Council, 1989 Symposium on Tectonic, Energy, and Mineral Resources of the Northwest Pacific, Russian Academy of Sciences, Khabarovsk, Russia, v. 2, p. 65-79 [in Russian].

Nokleberg, W.J., Moll-Stalcup, E.J., Miller, T.P., Prew, D.A., Grantz, A., Plafker, G., Moore, T.E., and Pattor. W.W., Jr., 1993, Tectono-stratigraphic terrane map of Al ska [abs.]: Geological Society of America Abstracts witl Programs, v. 25 , no. 5, p. 127-128.

O'Sullivan, P.B., Murphy, J.M., Moore, T.E., and Howell, D.G., 1993, Results of 110 apatite fission track analyses from the Brooks Range and North Slope of Northern Alaskr completed in cooperation with the Trans-Alaska Crustal Transect (TACT): U.S. Geological Survey Open-File Report 93-545, 107 p.

Patton, W.W., Jr., 1993, Ophiolitic terranes of northern and central Alaska and their correlatives in Canada and northeastern Russia [abs.]: Geological Society of America, At stracts with Programs, v. 25, no. 5, p. 132.

Pavlis, T.L., Sisson, V.B., Foster, H.L., Nokleberg, W.J., and Plafker, G., 1993, Mid-Cretaceous extensional tectonics of the YukonTanana terrane, Trans-Alaska Crustal Transect (TACT), eastcentral Alaska: Tectonics, v. 12, no. 1, p. 103-122.

Philpotts, John, Taylor, C., Evans, J., and Emsbc. P., 1993, Newly discovered molybdenite occurrences at Dora Bay, Prince of Wales Island, southeast Alaska, and preliminary scanning electron microscope studies, in Dusel-Pacon, Cynthia, and Till, A.B., eds., Geologic studies in Alaska by the U.S. Geological Survey, 1992: U.S. Geological Survey Bulletin 2068, p. 187-196.

Powers, R.B., ed., 1993, Petroleum exploration plays and resources estimates, 1989, onshore United States--Region 1, Alaska; Region 2, Pacific Coast: U.S. Geological Survey Bulletin 2034-A, 138 p.

Richter, D.H., Smith, J.G., Schmoll, H.R., and Smith, R.L., 1993, Geologic map of the Nabesna B-6 quadrangle, south-central Alaska: U.S. Geological Survey Geologic Quadrangle Map GQ-1688, 1 sheet, color, scale 1:63,360 
Schenk, C.J., and Bird, K.J., 1993, Depositional sequences in Lower Cretaceous rocks, Atigun syncline and Slope Mountain areas, Alaskan North Slope: U.S. Geological Survey Bulletin 2068, p. 48-58.

Schmidt, J.M., and Werdon, M.B., 1993, Clastic-hosted stratiform, vein/breccia and disseminated $\mathrm{Zn}-\mathrm{Pb}-\mathrm{Ag}$ deposits of the northwestern Brooks Range, AK-Are they different expressions of dewatering of the same source basin? [abs.]: Geological Society of America, Abstracts with Programs, v. 25, no. 5, p. 143.

Schneider, J.L., ed., 1993, 1993 Annual Report on Alaska's Mineral Resources: U.S. Geological Survey Circular 1102, 70 p.

Schumann, R.R., ed., prepared in cooperation with the U.S. Environmental Protection Agency, 1993, Geologic radon potential of EPA Region 10-Alaska, Idaho, Oregon, and Washington: U.S. Geological Survey Open-File Report 93-292-J, 146 p.

Selner, G.I., and Taylor, R.B., 1993, System 9, GSMap, and other programs for the IBM PC and compatible microcomputers, to assist workers in the earth sciences: U.S. Geological Survey Open-File Report 93-511, two 3-1/2" diskettes.

Stricker, G.D., and Affolter, R.H., 1993, Chemical characterization of Alaskan coal [abs.]: U.S. Geological Survey OpenFile Report 93-680, p. 3.

Tripp, R.B., and Cathrall, J.B., 1993, Hidden gems in the NURE data-Placer exploration potential for Au, PGM, REE, and other metals in the Arctic coastal plain and foothills provinces, Alaska: Explore (Newsletter for the Association of Exploration Geochemists), no. 79, April 1993, p. 10-12.

Tripp, R.B., Curtin, G.C., Nokleberg, W.J., Huston, D.L., and Hampton, J.R., 1993, Mineralogical maps showing distribution of selected ore-related minerals in the nonmagnetic, heavy-mineral-concentrate fraction of stream sediment from the Mount Hayes $1^{\circ} \times 3^{\circ}$ quadrangle, eastern Alaska Range, Alaska: U.S. Geological Survey Miscellaneous Field Studies Map MF-1996-E, 13 p., 3 sheets, scale 1:250,000.

Tripp, R.B., and King, H.D., 1993, Maps showing distribution of selected minerals in the nonmagnetic heavy-mineral fraction of stream-sediment samples, Medfra quadrangle, Alaska: U.S. Geological Survey Miscellaneous Field Studies Map MF-2207, 1 sheet, scale 1:250,000.

Watterson, J.R., 1993, Reply to comment on "Preliminary evidence for the involvement of budding bacteria in the origin of Alaskan placer gold": Geology, v. 21, no. 3, p. 280.

Weber, F.R., Wheeler, K.L., Rinehart, C.D., Chapman, R.M., and Blodgett, R.B., 1992, Geologic map of the Livengood quadrangle, Alaska: U.S. Geological Survey Open-File Report 92-0562, 1 sheet, scale 1:250,000.

Winkler, G.R., and Plafker, G., 1993, Geologic map of the Cordova and Middleton Island quadrangles, southern Alaska: U.S. Geological Survey Miscellaneous Investigations Series Map I-1984, scale 1:250,000.

\section{U.S. BUREAU OF MINES}

Andrews, G., 1993, Regulatory processes associated with metalmine development in Alaska-A case study of the Greens Creek Mine: U.S. Bureau of Mines Open-File Report 8393, 44 p.

Baer, R.L., Sherman, G.E., and Plumb, P.D., 1992, Submarine disposal of mill tailings from on-land sources-An overview and bibliography: U.S. Bureau of Mines Oper-File Report 89-92, 102 p.

Balen, M.D. and Allen, A.M. 1993, Alaskan minøral industry cost escalation factors: U.S. Bureau of Mines Open-File Report 76-93, $19 \mathrm{p}$.

Bittenbender, P.E., Maas, K.M., Still, J.C., and Redman, E.C., 1993, Mineral investigations in the Ketchikan Mining District, Alaska, 1992-Ketchikan to Hyder areas: U.S. Bureau of Mines Open-File Report 11-93, 88 p.

Cocklan-Vendl, M.E., and Hemming, J.E., 1993, A comparison of regulatory processes associated with metal-mine development in Alaska and British Columbia: U.S. Bureau of Mines Open-File Report 78-93, 18 p.

Coldwell, J.R., and Gensler, E.C., 1993, Potential for submarine tailings disposal to affect the availability of minerals from United States Coastal areas: U.S. Bureau of Mines OpenFile Report 101-93, 50 p.

Fechner, S.A., Burleigh, R.E., Foley, J.Y., and Lear, K.G., 1993, Results of the 1991-92 U.S. Bureau of Mines site-specific investigations project in Alaska: U.S. Bureau of Mines Open File Report 100-93, 127 p.

Foley, J.Y., 1993a, Magmatic chromite segregations in ultramafic sections of Alaskan ophiolites [abs.]: Geologic?l Society of America, Abstracts with Programs, v. 25, no. 5, p. 38.

1993b, Platinum-group elements in mafic and ultramafic rocks in Alaska [abs.]: Geological Society of America, Abstracts with Programs, v. 25, no. 5, p. 38.

Hesse, C.A., and Reim, K.M., 1993, Regulatory as jects of submarine tailings disposal-The Quartz Hill history: U.S. Bureau of Mines Open-File Report 66-93, 85 p.

Maas, K.M., Still, J.C., and Bittenbender, P.E.,1993, Bureau of Mines mineral investigations in the Ketchikan Mining District, Alaska 1990-92 [abs.]: Alaska Miners Association, Conference Juneau 1993, Juneau, Alaska, April 21-23, 1993, Abstracts of Professional Papers, p. 9-10.

Meyer, M.P., Kurtak, J.M., and Hicks, R.W., 1993, Pesults of the 1992 U.S. Bureau of Mines Colville Mining I strict study: U.S. Bureau of Mines Open-File Report 12-93, 35 p.

Minarik, R.J., Bundtzen, T.K., Swainbank, R.C., Wood, J.E., and Clough, A.H., 1993, Alaska, annual report 1931: U.S. Bureau of Mines, $12 \mathrm{p}$.

Plumb, P.D., and Gensler, E.C., 1993, Ecosystem management and mine permitting in Alaska: U.S. Bureau of Mines OpenFile Report 114-93, 39 p.

Poling, G.W., Ellis, D.V., Pelletier, C.A., Pedersen, T.F., and Hesse, C.A., 1993, North American examples. v.1 of Case studies of submarine tailings disposal: U.S. Bureau of Mines Open-File Report 89-93, 140 p.

Summers, C.A., Larson, D.E., and Werdon, M.B., 1993, Lead and zinc mineralization at Story Creek: Society for Mining, Metallurgy, and Exploration Annual Meeting, Reno, Nevada, February 15-18, 1993, Preprint 93-124, 7 p.

\section{MINERALS MANAGEMENT SERVICT:}

OCS Reports and Maps are authored by the MMS professional staff. OCS Studies are generally contractually prepared environmental, socioeconomic, and technological stıdies. 
Bacon, T., and Carns, J.L., 1993, Arctic fisheries databaseUser's manual: Minerals Management Service, OCS Study 93-0057, 58 p., plus Arctic fisheries data retriever 2.0, one 3.5" diskette, plus Arctic fisheries data base 2.0, one CDROM disc.

Brelsford, T., Fienup-Riordan, A., Jorgensen, J.G., McNabb, S., Petrivelli, P., Robbins, L.A., and Galginaitis, M., 1992, Key informant summaries, v. 1 of Social and economic studies, Schedule A regions (North Slope, NANA, Calista, AleutianPribilof), pt. I of Social indicators study of Alaskan coastal villages: Minerals Management Service, OCS Study 92$0031,449 \mathrm{p}$.

Clough, J.G., Robinson, M.S., Decker, J., and O'Sullivan, P.B., 1990, Bedrock geology of the Sadlerochit and Shublik Mountains and apatite fission-track thermal history of Permian to Tertiary sedimentary rocks in the Arctic National Wildlife Refuge, northeastern Alaska, in Hunt, M.C., Doenges, S., and Stubbs, G.S., eds., Second symposium on studies related to continental margins-A summary of year-three and yearfour activities-Proceedings: Austin, University of Texas, Bureau of Economic Geology, p. 18-24.

Cooke, L.W., 1991, Estimates of undiscovered, economically recoverable oil and gas resources for the Outer Continental Shelf, revised as of January 1990: Minerals Management Service, OCS Report 91-0051, 30 p.

Cooke, L.W., 1993, Resource evaluation and petroleum potential of the Beaufort and Chukchi Seas and Hope Basin: U.S. Minerals Management Service OCS Study, MMS-93-0043, p. 9-15.

Craig, J.D., Sherwood, K.W., and Hurlbert, S.B., 1993, Log evaluation of a hydrocarbon reservoir in the Burger well, Chukchi Sea [abs.]: American Association of Petroleum Geologists Annual Meeting, New Orleans, Abstracts with Program, p. 88.

Derksen, D.V., Bollinger, K.S., Esler, D., Jensen, K.C., Taylor, E.J., Miller, M.W., and Weller, M.W., 1992, Effects of aircraft on behavior and ecology of molting black brant near Teshekpuk Lake, Alaska: Minerals Management Service, OCS Study 92-0063, $227 \mathrm{p}$.

Endter-Wada, J., Hofmeister, J., Mason, R., McNabb, S., Morrison, E., Reynolds, S., Robbins, E., Robbins, L.A., Rook, C.T., and Jorgensen, J.G., 1993, Postspill key informant summaries-Schedule C communities, part 1 (Cordova, Tatitlek, Valdez) and part 2 (Kenai, Tyonek, Seldovia, Kodiak City, Karluk, Old Harbor, Chignik), pt. IV of Social indicators study of Alaskan coastal villages: Minerals Management Service, OCS Study 92-0052, 849 p.

Endter-Wada, J., Hofmeister, J., Mason, R., McNabb, S., Mulcahy, J., Robbins, L.A., and Jorgensen, J.G., 1992, Key informant summaries, v.1 of Social and economic studies, Schedule B regions (Bristol Bay, Kodiak, Bering Straits), pt. I of Social indicators study of Alaskan coastal villages: Minerals Management Service, OCS Study 92-0032, 432 p.

Endter-Wada, J., Robbins, L.A., Levine, D.W., Boxberger, D.L., Nohalty, P.D., Jorgensen, J.G., and McNabb, S.L., 1992, Bristol Bay subsistence harvest and sociocultural systems inventory: Minerals Management Service, OCS Study 920036, 426 p.

Francois, D.K., 1993, Federal offshore statistics, 1992: Minerals Management Service, OCS Report 93-0066, 155 p.

Horowitz, W.L., 1993, A correlation of the depositional environment and its relationship to diagenesis and reservoir quality of the Ivishak Formation [abs.]: American Ass 3ciation of Petroleum Geologists Annual Meeting, New Orleans, Abstracts with Program, p. 121.

Johnson, S.R., and Gazey, W.J., 1992, Design and testing of a monitoring program for Beaufort Sea waterfowl and marine birds: Minerals Management Service, OCS Study 92-0060, $114 \mathrm{p}$.

Johnson, W.R., Marshall, C., Anderson, C.M., and I ear, E.M., eds., 1993a, The analysis:, v. 1 of Oil-spill risk analysis, Cook Inlet/Shelikof Strait Outer Continental Shelf Lease: Sale 149: Minerals Management Service, OCS Report 93-0033, 99 p.

-1993b, Conditional risk contour maps of seasonal conditional probabilities, v. 2 of Oil-spill risk anal'sis, Cook Inlet/Shelikof Strait Outer Continental Shelf Lease Sale 149: Minerals Management Service, OCS Report 93-0034, 344 p.

Jorgensen, J.G., 1993, Research methodology-Desigr sampling, reliability, and validity, pt. II of Social indicators study of Alaskan coastal villages: Minerals Management Service, OCS Study 93-0035, 535 p.

LGL Research Associates and Alaska Department of Fish and Game, 1992, Use of Kasegaluk Lagoon, Chukchi Sea, Alaska, by marine birds and mammals: Minerals Management Service, OCS Study 92-0028, 627 p.

Loughlin, T.R., 1993, Status and pelagic distribution of Otariid pinnipeds in the Bering Sea during winter: Minerals Management Service, OCS Study 93-0026, 58 p.

Mast, R.F., Dolton, G.L., Crovelli, R.A., Root, D.H., and Attanasi, E.D., U.S. Geological Survey; Martin, P.E., Ccoke, L.W., Carpenter, G.B., Pecora, W.C., and Rose, M.B., Minerals Management Service; 1989, Estimates of undiscovered conventional oil and gas resources in the United Stat:s-A part of the Nation's energy endowment: Washington D.C., U.S. Department of the Interior, $44 \mathrm{p}$.

MBC Applied Environmental Sciences, 1993, Alaska OCS Region, Fifth Information Transfer Meeting, Anchorage, Alaska, 1993-Conference proceedings: Minerals M־nagement Service, OCS Study 93-0043, 318 p. plus appendixes.

McGurk, M.D., Edinger, J.E., and Buchak, E.M., 199₹, Fisheries oceanography of the southeast Bering Sea-Simulated dispersal of herring and sand lance larvae in Port Moller, Alaska, using a three-dimensional hydrodynamic model: Minerals Management Service, OCS Study 92-0055, 62 p.

Mendenhall, V.M., ed., 1993, Monitoring of populatiors and productivity of sea birds at Cape Peirce, Bluff, and Cane Thompson, Alaska, 1990: Minerals Management Service, OCS Study $92-0047,173$ p., plus appendixes.

Minerals Management Service, 1992a, Alaska regional studies plan-Final, FY 1993: Anchorage, Alaska, U.S. I' spartment of the Interior, Minerals Management Service, Alaska OCS Region, 167 p.

1992b, Comprehensive program 1992-1997--Summary and decision: Anchorage, Alaska, U.S. Department of the Interior, Minerals Management Service, Alaska OC ${ }^{\circledR}$ Region, $38 \mathrm{p}$., plus appendixes.

O'Sullivan, P.B., 1988, Apatite fission-track study of the thermal history of Permian to Tertiary sedimentary rocks in the Arctic National Wildlife Refuge, northeastern Alaska: Fairbanks, University of Alaska, M.S. thesis, 184 p.

O'Sullivan, P.B., Decker J.E., and Bergman, S.C., 1989, Apatite fission-track study of the thermal history of Fermian to 
Tertiary sedimentary rocks in the Arctic National Wildlife Refuge, northeastern Alaska: Geological Society of America, Abstracts with Programs, v. 21, p. 126.

Risley, D.E., Martin, G.C., Lynch, M.B., Flett, T.O., Larson, J.A, Horowitz, W.L., and Turner, R.F., eds., 1992, Geologic report for the Gulf of Alaska planning area: Minerals Management Service, OCS Report 92-0065, 302 p., plus appendixes and plates.

Schumacher, J.D., and Reed, R.K., 1993, Circulation and crossshelf transport and exchange along the Bering Sea continental shelf edge: Minerals Management Service, OCS Study 93-0027, $40 \mathrm{p}$.

Treacy, S.D., 1993, Aerial survey of endangered whales in the Beaufort Sea, Fall 1992: Minerals Management Service, OCS Study 93-0023, 74 p., plus appendixes.

Truett, J.C., 1993, Guidelines for oil and gas operations in polar bear habitats: Minerals Management Service, OCS Study 93-0008, $104 \mathrm{p}$.

Wainwright, T.C., Armstrong, D.A., Andersen, H.B., Dinnel, P.A., Herren, D.W., Jensen, G.C., Orensanz, J.M., and Shaffer, J.A., 1992, Coastal fisheries oceanography of the southern Bering Sea and North Aleutian Basin-Port Moller king crab studies: Minerals Management Service, OCS Study 92-0040, 164 p.

\section{BUREAU OF LAND MANAGEMENT}

Banet, Arthur C., Jr., 1993a, A geochemical profile and burial history of Aurora 890 \#1 OCS Y -0943 well, offshore of the ANWR 1002 area, northeast Alaska: Anchorage, Alaska, Bureau of Land Management Technical Report 16.

-1993b, The Aurora well-Its impact on the Arctic National Wildlife Refuge oil and gas assessment: American Association of Petroleum Geologists Bulletin, v. 77, no. 3.

-1994a, A comparison of crude oil chemistry on the American North Slope-Chukchi Sea-MacKenzie Delta: Anchorage, Alaska, Bureau of Land Management Technical Report [in press].

- 1994b, A compendium of North Slope crude oil chemistry: American Association of Petroleum Geologists Bulletin [in press].

-1994c, Geochemical classification of oils from Chukchi Sea, northwest Alaska: American Association of Petroleum Geologists Bulletin [in press].

-1994d, Geological and geochemical analysis of the Aurora well, offshore of the Arctic National Wildlife Refuge 1002 area, in Proceedings of the First International Conference on Arctic Margins, Minerals Management Service Special Publication [in press].

Mowatt, T.C., and Banet, A.C., Jr., 1993, Petrography of selected Aurora well samples, Beaufort Sea, northeast Alaska [abs.]: American Association of Petroleum Geologists Bulletin, v. 77 , no. 3 .

-1994a, Petrography and petrology of the Tapkaurak and Oruktalik Sands, Aurora well, Beaufort Sea, Alaska: Anchorage, Alaska, Bureau of Land Management Technical Report [in press].

-1994b, Petrology of selected outcrop samples from the Arctic National Wildlife 1002 Area, in Proceedings of the First International Conference on Arctic Margins: Minerals Management Service Special Publication [in press].

\section{NATIONAL PARK SERVICE}

Densmore, Roseann, 1994, Succession on regraded placer mine soils in Alaska in relation to initial site characteristics: Arctic and Alpine Research [in press].

Karle, Kenneth, and Densmore, R., 1994, Stream and flood-plain restoration in a riparian ecosystem disturbed by placer mining: Ecological Engineering [in press].

\section{U.S. FISH AND WILDLIFE SERVICE}

Amstrup, S.C. 1993, Human disturbances of denniñ polar bears in Alaska: Arctic, v. 43 , no. 3, p. 246-250.

Amstrup, S.C., and Gardner, C., 1994, Polar bear maternity denning in the Beaufort Sea: Journal of Wildlife Management, v. 58 , no. 1 , p. $1-10$.

Bodkin, J.L., Mulcahy, D., and Lensink, C.J., 1993, Age-specific reproduction in female sea otters (Enhydra lutris) from southcentral Alaska-Analysis of reproductive tracts: Canadian Journal of Zoology, v. 71, no. 9, p. 1811-1815.

Brackney, A.W., and Hupp, J.W., 1993, Autumn diet of lesser snow geese staging in northeastern Alaska: Journal of Wildlife Management, v. 57, no. 1, p. 55-61.

Emers, M., Jorgenson, J.C., Raynolds, M.K., Willms, M.A., and Welp, L.A., 1992, Long-term effects of winte- seismic exploration on the vegetation of the coastal plain of the Arctic National Wildlife Refuge: Fairbanks, Alaska, UJ.S. Fish and Wildlife Service, Annual Progress Report 1992, 105 p.

Garrott, R.A., Eberhardt, L.L., and Burn, D.M., 1993, Mortality of sea otters in Prince William Sound following the Exxon Valdez oil spill: Marine Mammal Science, v. 9, no. 4, p. 343-359.

Joria, P.E, 1992, LANDSAT-TM vegetation map for eastern portion of Arctic National Wildlife Refuge coastal plain: Anchorage, Alaska, U.S. Fish and Wildlife Service, 1 sheet, scale 1:200,000.

Lipscomb, T.P., Harris, R.K., Moeller, R.B, Pletcher, J.M., Haebler, R.J., and Ballachey, B.E., 1993, Histopath logic lesions in sea otters exposed to crude oil: Veterinary Pathology, v. 30 , p. $1-11$.

Lyons, S.M., and Trawicki, J.M., 1993, Water resocrce inventory and assessment, Arctic National Wildlife Refuge. 1992 stream discharge gaging data: Anchorage, Alaska, U.S. Fish and Wildlife Service, Alaska Fisheries Progress Report, 107 p.

Reynolds, P.E., 1993, Dynamics of muskox groups in northeastern Alaska: Rangifer, v. 13, no. 2, p. 83-89.

Snyder-Conn, E., Mueller, K.A., and Doyle., T.J., 1993, Contaminant baseline data for water, sediments, and $\mathrm{f}$ h of the Selawik National Wildlife Refuge, Alaska, 1987-88-Final Draft: Fairbanks, Alaska, U.S. Fish and Wi'dlife Service Technical Report NAES-TR-93-01.

\section{DEPARTMENT OF ENERGY}

Pittsburgh Energy Technology Center, 1993, Final environmental impact statement for the proposed Healy Clean Coal Project: Pittsburgh Energy Technology Center, DOE/EIS-0186, $1100 \mathrm{p}$. 


\section{NON-FEDERAL REPORTS}

\section{ALASKA DIVISION OF GEOLOGICAL AND GEOPHYSICAL SURVEYS}

Alaska Division of Geological and Geophysical Surveys, 1993a, Estimated mineral potential of lands available for State selection, 1991-1993: Alaska Division of Geological and Geophysical Surveys Public-Data File 93-0, 189 p.

-1993b, Trace element and major oxide analyses of samples from the Eagle and Tanacross quadrangles, east-central Alaska: Alaska Division of Geological and Geophysical Surveys Public-Data File 93-4, 31 p., 1 sheet, scale 1:250,000.

-1993c, Land selection unit 14 (Goodnews Bay quadrangle)—Geologic summary, references, DGGS sample locations, geochemical and major oxide data: Alaska Division of Geological and Geophysical Surveys Public-Data File 93-14, 18 p., 1 sheet, scale 1:250,000.

Bundtzen, T.K., Laird, G.M., Harris, E.E., Kline, J.T., and Miller, M.L., 1993, Geologic map of Sleetmute C-7, D-7, C-8, and D-8 quadrangles, Horn Mountains area, southwest Alaska: Alaska Division of Geological and Geophysical Surveys Public-Data File 93-47, 15 p., 2 sheets, scale 1:63,360.

Burns, L.E., and Gilbert, W.G., 1993, Land selection unit 36 (Haines unit, Skagway quadrangle)—Geologic summary, references, DGGS sample locations, geochemical and major oxide data: Alaska Division of Geological and Geophysical Surveys Public-Data File 93-36, 31 p., 2 sheets, scale 1:63,360.

Burns, L.E., and Pessel, G.H., 1993, Land selection unit 1 (Tiekel unit, Valdez quadrangle)_Geologic summary, references, DGGS sample locations, geochemical and major oxide data: Alaska Division of Geological and Geophysical Surveys Public-Data File 93-1, 11 p., 1 sheet, scale 1:250,000.

Clautice, K.H., Bowman, N.C., Clough, J.G., Gilbert, W.G., Kline, J.T., Smith, T.E., and Blodgett, R.B., 1993, Land selection unit 8 (Kantishna River, Ruby, and Medfra quadrangles)References, lead isotope, geochemical and major oxide data: Alaska Division of Geological and Geophysical Surveys Public-Data File 93-8, 46 p., 1 sheet, scale 1:250,000.

Clautice, K.H., Bundtzen, T.K., and Liss, S.A., 1993, Land selection unit 3 (Healy, Mount Hayes, Talkeetna Mountains, and Gulkana quadrangles)-References, major oxide and geochemical data: Alaska Division of Geological and Geophysical Surveys Public-Data File 93-3, 29 p., 1 sheet, scale 1:250,000.

Clautice, K.H., Burns, L.E., and Liss, S.A., 1993, Land selection unit 31 (Bettles, Beaver, Wiseman and Chandalar quadrangles)-References, geochemical and major oxide data: Alaska Division of Geological and Geophysical Surveys PublicData File 93-30a, 21 p., 1 sheet, scale 1:250,000.

Clautice, K.H., Burns, L.E., and Newberry, R.J., 1993, Land selection unit 5 (Big Delta, Mount Hayes, and Fairbanks quadrangles)-References, major oxide and geochemical data: Alaska Division of Geological and Geophysical Surveys Public-Data File 93-5, 18 p., 1 sheet, scale 1:250,000.

Clautice, K.H., and Still, J.C., 1993, Preliminary report on galena lead isotopes from the Hyder area, southeast Alaska: Alaska Division of Geological and Geophysical Surveys PublicData File 93-45, 10 p., 1 sheet, scale 1:63,360.

Clough, J.G., 1993, Squirrel River evaluation unit 22-Baird Mountains, Selawik, and Noatak quadrangles, northwest
Alaska-Geologic summary and bibliography: Al`ska Division of Geological and Geophysical Surveys Pıblic-Data File 93-22, 6 p.

Clough, J.G., Robinson, M.S., Clautice, K.H., and Blodgett, R.B., 1993, Evaluation unit 35-Charley River and Black River quadrangles, east-central Alaska-Genercl geology and geochemical, major oxide, and lead isotope data: Alaska Division of Geological and Geophysical Survey's PublicData File 93-35, 15 p., 1 sheet, scale 1:250,000.

Combellick, R.A., 1993, Geologic hazards in and nea proposed State of Alaska oil and gas lease sale 79 (Cape Yakatage): Alaska Division of Geological and Geophysicel Surveys Public-Data File 93-81, 11 p.

Combellick, R.A., Campbell, K.M., and Cruse, G.R., compilers, 1993a, Derivative geologic-materials map of the Big Delta quadrangle, Alaska: Alaska Division of Geologica' and Geophysical Surveys Public-Data File 93-55, 1 sl set, scale $1: 250,000$.

1993b, Derivative geologic-materials map of the Chandalar quadrangle, Alaska: Alaska Division of Geol -gical and Geophysical Surveys Public-Data File 93-57, $1 \mathrm{~s}^{\text {h }}$ eet, scale $1: 250,000$.

-1993c, Derivative geologic-materials map of the northwestern Nabesna quadrangle, Alaska: Alaska Division of Geological and Geophysical Surveys Public-Data File 9366,1 sheet, scale 1:250,000.

1993d, Derivative geologic-materials map of the southeastern Wiseman quadrangle, Alaska: Alaska Division of Geological and Geophysical Surveys Public-Data File 9376, 1 sheet, scale 1:250,000.

Combellick, R.A., Clement, R.F., and Cruse, G.R., compilers, 1993, Derivative geologic-materials map of the Baird Mountains quadrangle, Alaska: Alaska Division of Geological and Geophysical Surveys Public-Data File 93-52, 1 sheet, scale 1:250,000.

Eckstein, M.K., Lateral facies changes in the Carboniforous Lisburne Group along the Aichilik transect, northeastern Alaska: Alaska Division of Geological and Geophysical Surveys Public-Data File 93-42, 19 p.

Liss, S.A., Robinson, M.S., Burns, L.E., and Nye, C.J., 1993, Land selection unit 32 (Shungnak, Hughes, and Melozitna quadrangles)-Geochemistry, major oxides, sample locations and reference data: Alaska Division of Geological and Geophysical Surveys Public-Data File 93-32, 23 p., 1 sheet, scale 1:250,000.

Motyka, R.J., Liss, S.A., Nye, C.J., and Moorman, M.A., 1993, Geothermal resources of the Aleutian Arc: Alaska Division of Geological and Geophysical Surveys Professional Report 114 , scale 1:1,000,000 [in press].

Ray, S.R., 1993, Hydrologic and water quality investigations related to placer mining in Interior Alaska-Summer 1992: Alaska Division of Geological and Geophysical Surveys Public-Data File 93-46, 84 p.

Ray, S.R., and Morgan, B., 1993, Investigation of stream sediment loads related to placer mining in the upper Birch Creek Basin, Alaska-Preliminary TMDL data collecticn: Alaska Division of Geological and Geophysical Survey's PublicData File $93-40,35$ p.

Reifenstuhl, R.R., Mull, C.G., Harris, E.E., Plumb, E.W., and Clough, J.C., 1993, Preliminary bedrock geologic map of the 
Philip Smith Mountains D-3 quadrangle, northeastern Brooks Range, Alaska: Alaska Division of Geological and Geophysical Surveys Public-Data File 93-80, 1 sheet, scale 1:63,360.

Reifenstuhl, R.R., Mull, C.G., Pessel, G.H., and Myers, M.D., 1993, Preliminary bedrock geologic map of the Philip Smith Mountains C-4 quadrangle, northeastern Brooks Range, Alaska: Alaska Division of Geological and Geophysical Surveys Public-Data File 93-30c, 11 p., 1 sheet, scale 1:63,360.

Robinson, M.S., 1993, Kriged surfaces of selected trace elements from stream-sediment samples collected in the Livengood B-3, B-4, C-3, and C-4 quadrangles, east-central Alaska: Alaska Division of Geological and Geophysical Surveys Public-Data File 93-79, 35 p.

Solie, D.N., Bundtzen, T.K., Bowman, N.D., and Cruse, G.R., 1993, Land selection unit 18 (Melozitna, Ruby, Nulato, and Kateel River quadrangles)-References, DGGS sample locations, geochemical and major oxide data: Alaska Division of Geological and Geophysical Surveys Public-Data File 9318, 20 p., 1 sheet, scale 1:250,000.

1993, Land selection unit 33 (Melozitna and Tanana quadrangles)-References, DGGS sample locations, geochemical and major oxide data: Alaska Division of Geological and Geophysical Surveys Public-Data File 93-33, 10 p.

Solie, D.N., Harris, E.E., Bundtzen, T.K., Wiltse, M.A., Newberry, R.J., Kline, J.T., and Smith, T.E., 1993, Land selection unit 16 (Selawik, Candle, Norton Bay, Unalakleet, Kateel River, and Nulato quadrangles)_-References, DGGS sample locations, geochemical and major oxide data: Alaska Division of Geological and Geophysical Surveys Public-Data File 93-16a, 54 p., 2 sheets, scale 1:250,000.

Solie, D.N., Werdon, M.B., Nye, C.J., and Combellick, R.A., 1993, Land selection unit 6 (Tyonek quadrangle)-References, DGGS sample locations, geochemical and major oxide data: Alaska Division of Geological and Geophysical Surveys Public-Data File 93-6, 11 p.

1993, Land selection unit 7 (Tyonek and Kenai quadrangles)-References, DGGS sample locations, geochemical and major oxide data: Alaska Division of Geological and Geophysical Surveys Public-Data File 93-7, 11 p.

Solie, D.N., Wiltse, M.A., Gilbert, W.G., and Kline, J.T., 1993, Land selection unit 17 (Nulato quadrangle)-References, DGGS sample locations, geochemical and major oxide data: Alaska Division of Geological and Geophysical Surveys Public-Data File 93-17, 16 p.

Solie, D.N., Wiltse, M.A., Harris, E.E., and Roe, J.T., 1993, Land selection unit 34 (Bettles and Tanana quadrangles)-References, DGGS sample locations, geochemical and major oxide data: Alaska Division of Geological and Geophysical Surveys Public-Data File 93-34, 42 p., 1 sheet, scale 1:250,000.

Sturmann, A.G., and Clement, R.F., 1993, Historical mining regions and districts of Alaska: Alaska Division of Geological and Geophysical Surveys Public-Data File 93-49, 1 sheet, scale $1: 250,000$.

Swainbank, R.C., Bundtzen, T.K., Clough, A.H., Hansen, E.W., and Nelson, M.G., 1993, Alaska's mineral industry 1992: Alaska Division of Geological and Geophysical Surveys Special Report 47, 80 p.

Wiltse, M.A., Reger, R.D., Newberry, R.J., Pessel, G.H., Pinney, D.S., Robinson, M.S., and Solie, D.N., 1993, Interim geologic map of the Circle Mining District: Alaska Division of
Geological and Geophysical Surveys Public-I ata File 9386,1 sheet, scale 1:63,360.

Wiltse, M.A., and Solie, D.N., 1993, Land selection unit 2 (Nabesna quadrangle)-References, DGGS samr'e locations, trace element and major oxide data: Alaska Division of Geological and Geophysical Surveys Public-Dat` File 93-2, $16 \mathrm{p}$., 1 sheet, scale $1: 250,000$.

\section{ADDITIONAL NON-FEDERAL PUBLICAT'ONS}

Alaska Miner, 1993, Historical perspective of Fort Knox ore body: Alaska Miner, v. 21, no. 6, p. 15, 22.

Bandopadhyay, Sukumar, and Nelson, M.G., eds., 1992, Mining in the Arctic-Proceedings of the Second International Symposium on Mining in the Arctic, Fairbanks, Alaska, 1992: Rotterdam, Netherlands, Balkema, 315 p.

Bence, A.E., and Douglas, G.S., 1993, The natural petroleum hydrocarbon background in the benthic sediments of Prince William Sound, Alaska [abs.]: Geological Society of America, Abstracts with Programs, v. 25, no. 6, p. A151.

Bond, R., 1993, Copper-gold mineralization of the Kasaan Peninsula [abs.]: Alaska Miners Association, Conference Juneau 1993, Juneau, Alaska, April 21-23, 1993, Abstracts of Professional Papers, p. 17.

Buxton, C., Petsel, S., and Kirkham, A., 1993, Gold-bearing vein systems at the Kensington project, southeast Alaska [abs.]: Alaska Miners Association, Conference June?u 1993, Juneau, Alaska, April 21-23, 1993, Abstracts of Professional Papers, p. 29-31.

California Mining Journal, 1993, Alaska's mineral resources: California Mining Journal, v. 62, no. 9, p. 10-12.

Calvin, James, 1993, The mining industry's best keft secret-The economic benefits of mining in southeast Alaska [abs.]: Alaska Miners Association, Conference Juneau 1993, J'neau, Alaska, April 21-23, 1993, Abstracts of Professional Paprss, p. 47.

Cao, S., Tang, J., Liu, J., and Lerche, I., 1993, Chul hi Sea planning area, Alaska-Basement motion, burial history, thermal maturation and hydrocarbon generation [abs.]: American Association of Petroleum Geologists, Annual Meeting, 1993, New Orleans, Louisiana, Program, p. 82.

Carter, K., and Lerche, I., 1993, Hydrocarbon potertial of the St. George Basin, Bering Sea, Alaska, in Vorren, T.O., Bergsager, E., Dahl-Stammes, O.A., Holter, E., Johansen, B., Lie, E., and Lund, T.B., Arctic geology and petroleum potential: Amsterdam, Netherlands, Elsevier, Norwegian Petroleum Society Special Publication 2, p. 173-194.

Christensen, T.R., 1993, Methane emissions from Arctic tundra: Biogeochemistry, v. 21, no. 2, p. 117-139.

Collins, C.M., Racine, C.H., and Walsh, M.E., 1993, Fate and effects of crude oil spilled on subarctic permafrost terrain in interior Alaska-Fifteen years later: Hanover, New Hampshire, U.S. Army Cold Regions Research and Engineering Laboratory Report 93-13, 20 p.

Conference Juneau 1993, 1993, Abstracts of Professional Papers: Juneau, Alaska, Alaska Miners Association.

Deming, David, 1993, Regional permeability estimates from investigations of coupled heat and groundwater flow, North Slope of Alaska: Journal of Geophysical Research, v. 98, no. B9, p. 16,271-16,286. 
Fredericksen, R.S., 1993, Progress report on the A-J project [abs.]: Alaska Miners Association, Conference Juneau 1993, Juneau, Alaska, April 21-23, 1993, Abstracts of Professional Papers, p. 27-28.

Garrett, D.E., 1992, Natural soda ash-Occurrences, processing, and use: New York, Van Nostrand Reinhold (Alaska, p. 165167).

Green, G.K., and Harbuck, D.D., 1993, Rare earth recovery from Bokan Mountain, Alaska [abs.]: Alaska Miners Association, Conference Juneau 1993, Juneau, Alaska, April 21-23, 1993, Abstracts of Professional Papers, p. 15.

Harrison, E.D., 1993, Greens Creek-An update [abs.]: Alaska Miners Association, Conference Juneau 1993, Juneau, Alaska, April 21-23, 1993, Abstracts of Professional Papers, p. 49.

Hedderly-Smith, D.A., 1993, Gold-copper mineralization in the Dolomi-Chasina Point area, Prince of Wales Island, Alaska [abs.]: Alaska Miners Association, Conference Juneau 1993, Juneau, Alaska, April 21-23, 1993, Abstracts of Professional Papers, p. 13-14.

Heffernan, Virginia, 1993, Echo Bay granted Alaskan permit: Northern Miner, v. 79, no. 16, June 21, p. 1.

Horowitz, W.L., 1993, A correlation of the depositional environments and its relationship to diagenesis and reservoir quality of the Ivishak Formation, Beaufort Sea, Alaska [abs.]: American Association of Petroleum Geologists, Annual Meeting, 1993, New Orleans, Louisiana, Program, p. 121.

Isaacs, Jonathan, 1990, Ocean management capacity in the State of Alaska-Bridging resources in State and Federal waters, in Our coastal experience-Assessing the past, confronting the future: Coastal Society, International Conference, 12th, San Antonio, Texas, 1990, Proceedings, p. 7-17.

Knight, J., 1993, Comment on "Preliminary evidence for the involvement of budding bacteria in the origin of Alaskan placer gold:" Geology, v. 21, no. 3, p. 279-280.

Kupecz, J.A., 1993, Reservoir potential of a major source rockUpper Triassic Shublik Formation, Prudhoe Bay, Alaska [abs.]: American Association of Petroleum Geologists, Annual Meeting, 1993, New Orleans, Louisiana, Program, p. 133.

Lagoe, M.B., and Zellers, S.D., 1993, Complementary subsurface stratigraphic analysis using microfossil distributions and seismic interpretation-An example from southern Alaska [abs.]: American Association of Petroleum Geologists, Annual Meeting, 1993, New Orleans, Louisiana, Program, p. 133134.

Lowenstern, J.B., 1993, Evidence for a copper-bearing fluid in magma erupted at the Valley of Ten Thousand Smokes, Alaska: Contributions to Mineralogy and Petrology, v. 114, no. 3, p. 409-421.

Madonna, J.A., 1988, Precious metal recovery using sluice boxes in Alaska and Canada, in Brawner, C.O., ed., Gold Mining '88, International Conference on Gold Mining, 2nd, Vancouver, British Columbia, Canada, 1988: Littleton, Colorado, Society of Mining Engineers, p. 385-396.

Mapmakers, 1993, Cook Inlet lease map-Updated oil and gas lease map covering lease ownership, lease operators and partners, lease numbers and expiration dates, bonus bids at State lease sales, unit ownership, oil and gas fields, field production data, platforms and operators, exploratory wells, and pipelines: Palmer, Alaska, The Mapmakers, 2 sheets.
Mason Map Service and International Oil Scouts Association, 1993, International oil and gas development-Yearbook (review of 1992)-Annual review of oil and gas exploration by fields in the United States, Canada, and foreign: Austin, Texas, Mason Map Service Incorporated, v. 63, Exploration (Alaska, p. 4-5).

Meyers, M., Smith, T.N., Krouskop, D.L., and Ryherd, T.J., 1993, Sequence stratigraphy of the Cretaceous Nanushuk Group, central North Slope, Alaska-Slope Mountain outcrop to the Lupine \#1 well [abs.]: American Ass ?ciation of Petroleum Geologists, Annual Meeting, 1993, Nevv Orleans, Louisiana, Program, p. 151.

Miller, M.B., 1993, Lithofacies mapping and reservo:r potential of the Kekiktuk Formation, North Slope, Alarka [abs.]: American Association of Petroleum Geologists, Annual Meeting, 1993, New Orleans, Louisiana, Program, p. 151.

Newkirk, S.R., Block, W.C., and Anderson, P.W., 1933, Recent developments at the Trocadero Bay (Big Harbor) prospect: A Descon-hosted VMS system, southern Prince of Wales Island [abs.]: Alaska Miners Association, Conference Juneau 1993, Juneau, Alaska, April 21-23, 1993, Abstrarts of Professional Papers, p. 35.

Oil and Gas Journal, 1993, ARCO's Cook Inlet, Beaufort strikes possible giants: Oil and Gas Journal, v. 91, no. 16, p. 20-21.

-1993, ARCO starts up North Slope field: Oil and Gas Journal, v. 91 , no. 17 , p. 27.

1993, Alaska's Cook Inlet basin slated for rebound in drilling: Oil and Gas Journal, v. 91, no. 21, p. 23-26.

1993, Alaska's North Slope/Beaufort region see: E\&D resurgence: Oil and Gas Journal, v. 91, no. 22, p. 15-19.

1993, GAO_ANWR plain likely to hold commercial oil: Oil and Gas Journal, v. 91, no. 35, p. 40.

Pacific Oil World, 1993, Echo Bay mines may reopen AlaskaJuneau gold mine: Pacific Oil World, v. 82, no. 11, p. 21.

1993, North Slope, Cook Inlet activity boosts 1 igh prices at Sale 76: Pacific Oil World, v. 85, no. 3, p. 6-8, 10-11.

1993, Arco tests Colville High area for sufficient oil reserves: Pacific Oil World, v. 85, no. 3, p. 13.

Pan, Guocheng, and Harris, D.P., 1993, Delineation of intrinsic geological units: Mathematical Geology, v. 25, no. 1, p. 9-39.

Post, R.A., 1990, Effects of petroleum operations in Alaskan wetlands-A critique: Juneau, Alaska, Alaska Departm $m$ nt of Fish and Game, Habitat Division, Technical Report 90-3, 112 p.

Rintoul, Bill, 1993, The North Slope's “money express": Pacific Oil World, v. 85, no. 1, p. 12-17.

Robison, V.D., Liro, L.M., Russo, J.W., Dawson, W.C.. 1993, Integrated geochemical and sequence stratigraphic analysis of the Triassic Shublik Formation, Tenneco Phoenix \#1 well, North Slope, Alaska [abs.]: American Association of Petroleum Geologists, Annual Meeting, 1993, New Orleans, Louisiana, Program, p. 172-173.

Siems, P.L., 1993, Lecture manual-"Wall-rock alteration for mineral exploration" workshop: Moscow, Idaho, University of Idaho, College of Mines and Earth Resources, Economic Geology Unit.

Smith, T.N., and Clough, J.G., 1993, Coalbed methane potential for Alaska [abs.]: American Association of Petroleum Geologists, Annual Meeting, 1993, New Orleans, Louisiana, Program, p. 184.

Sorensen, Jean, 1993, Alaska offers opportunities for exploration companies: Northern Miner, v. 79, no. 13, p. B10. 
Taylor, E.F., 1993, Early exploration for hydrocarbons in the North American Arctic [abs.]: Geological Society of America, Abstracts with Programs, v. 25, no. 6, p. A207.

Third Glacier Bay Science Symposium, 1993, Program with Abstracts: U.S. National Park Service and Friends of Glacier Bay [P.O. Box 135, Gustavus, Alaska, 99826], unpaged.

Thomas, C.P., and others, 1993, Alaska North Slope National Energy Strategy Initiative-Analysis of five undeveloped fields: Bartlesville, Oklahoma, U.S. Department of Energy, Bartlesville Project Office, DOE/ID/01570-T164 (DE93000142), variously paged.

Varnavshiy, V.G., 1993, Geologic position and structure of sedimentary basins: Petroleum Geology, v. 27 , no. 1/2, p. 1-8.

Varnavskiy, V.G., Kirillova, G.L., Krapiventseva, V.V, and Kuznetsov, V.Ye., 1993, Characteristics of lithologic-structural associations of complexes of the sedimentary basins: Petroleum Geology, v. 27, no. 1/2, p. 9-35.

Vorren, T.O., Bergsager, E., Dahl-Stammes, O.A., Holter, E., Johansen, B., Lie, E., and Lund, T.B., 1993, Arctic geology and petroleum potential: Amsterdam, Netherlands, Elsevier, Norwegian Petroleum Society Special Publication 2, 751 p.

World Oil, 1993, 1992 Cook Inlet find confirmed, added to: World Oil, v. 214 , no. 3 , p. 23.

Yu, Z., Li, Y., and Lerche, I., 1993, Thermal history and hydrocarbon maturity study in the Norton Basin, Alaska [abs.]: American Association of Petroleum Geologists, Annual Meeting, 1993, New Orleans, Louisiana, Program, p. 205.

\section{APPENDIX 2.-ROLES OF FEDERAL AGENCIES IN MINERAL PROGRAMS}

\section{DEPARTMENT OF THE INTERIOR}

\section{U.S. GEOLOGICAL SURVEY}

The mission of the USGS is to develop and interpret the geologic, topographic, and hydrologic data necessary for prudent management of the Nation's minerals, land, and water. The USGS carries out its mission through research that produces geographic, cartographic, and remotely sensed information; geologic, geochemical, and geophysical maps and studies; energy, mineral, and water resource assessments; geohazards research, including toxic waste studies; and participation in multidisciplinary projects, maintaining data bases, and publishing reports and maps.

Among other geologic activities in Alaska, the USGS is active in assessing minerals, including metalliferous and energy resources. Field and laboratory researchers also gather information about domestic petroleum, coal, uranium, and geothermal resources. At the request of land-managing agencies, the USGS provides mineral-resource assessments for land planning, including wilderness studies. Within Alaska, the USGS maintains offices for its Geologic, National Mapping, and Water Resources Divisions. Within the Geologic Division, the Branch of Alaskan Geology is the primary USGS office studying mineral resources in Alaska; the Branch is headquartered in Anchorage with a field office in Fairbanks. Other Alaskan Branch geologists are stationed in Menlo Park, California. During the summer field season, many USGS scientists from other branches within the Geologic Division conduct mineral-related research in Alaska. In this report, specific information on USG ${ }^{\top}$ programs, projects, and data bases is given under the USGS heading in the "Activities by Federal Agencies" sections of the chapters on Oil and Gas Resources, Coal and Peat Resources, Uranium Resources, Metallic Minerals, and Industrial Minerals.

\section{U.S. BUREAU OF MINES}

The mission of the USBM is to help ensure that our country has an adequate, dependable supply of minerals and materials to meet its national security and economic needs at acceptable social, environmental, and econonic costs. In 1993, the USBM's Alaska Field Operations Center (AFOC) had headquarters in Anchorage and an office in Juneau. The AFOC carries out its mission through five programs:

1. Minerals availability program.-This program is part of a worldwide USBM program responsible for developing the Minerals Availability System (MAS) computer data base and the Minerals Industry Location System (MILS), a subset of MAS. MILS contains basic information about the identification and location of known mineral denosits. MAS is more extensive, containing information about reserve estimates, mineral extraction and beneficiation methodologies, environmental constraints to mining, and cost analyses for selected major mineral deposits. A computer and communication system allow the information to be stored, manipulated, and retrieved as computer-plotted map overlays and printouts of MAS/MILS data, enabling rapid and uniform development of cost data for MAS mineral-denosit evaluations. MAS and MILS mineral-deposit data are cross-indexed to several other minerals-information data bases.

2. Policy analysis.-This program em ohasizes the analysis of newly developed and existing mineral data to interpret their significance in the context of lical and national mineral needs. Assessment of technical, institutional, political, social, and economic factors that affect the supply of, and demand for, domestic and international minerals is the key to identifying mineral issues.

3. State mineral activities.-This prorram covers minerals-related activities in Alaska and assist: in developing and releasing nonfuel-mineral-industry information. The program also provides the USBM with direct communication to the ADGGS, the Alaska Division of Mining, other minerals-oriented government agencies, industry, private firms, and individuals. The USBM collerts, analyzes, and reports mineral data and develops information regarding activities and trends in the mining industry. This program produces the annual USBM Minerals Yearbook chapters and Mineral Industry Surveys. 
4. Mineral land assessment.-This is the USBM's major Alaskan program, conducted in cooperation with other Federal and State agencies. Mineral assessments are both areal and commodity-oriented. In support of the Secretary of the Interior's mandate to assess the mineral potential of public lands in Alaska, the AFOC initiated a program in 1985 to evaluate mineral resources of the mining districts in the State. The program seeks to identify the type, amount, and distribution of mineral deposits; related studies will determine their economic feasibility. Legislative effects on mineral development will also be addressed. The USBM has completed its study of the Juneau and Valdez Creek Mining Districts; studies of the Colville and Ketchikan Mining Districts are in progress. The USBM also provides minerals data in support of USFS and BLM activities in Alaska. The USBM acts as a mineral information resource in support of USFS planning statewide and assists the USFS in identification of mine hazards.

A statewide program provides an inventory and specific technical evaluations of Alaska's strategic and critical mineral and advanced materials deposits on Federal lands that are closed to mineral entry and on lands that are open to entry but not of current interest to industry. In addition to locating, mapping, and estimating the size and grade of deposits, the USBM obtains bulk samples for metallurgic research to determine recovery and extraction methods and costs. These studies are undertaken in cooperation with the USBM Research Centers in Albany, Oregon, and Salt Lake City, Utah. These investigations provide reserve estimates of marginal and submarginal deposits in Alaska and its coastal waters.

5. Minerals research.-The USBM is attempting to provide solutions to mining, mineral recovery, and environmental problems in Alaska through a number of research efforts and technology transfer. Several research projects are currently being conducted in Alaska by USBM research centers or at universities sponsored by the USBM's Mineral Institute Program. USBM and university research centers cooperate with the AFOC to solve mineral utilization problems.

\section{MINERALS MANAGEMENT SERVICE}

The MMS was created in 1982 with a twofold mission: (1) to collect and disburse revenues generated from mineral leases on Federal and Indian lands, and (2) to oversee the orderly development of America's offshore energy and mineral resources while properly safeguarding the environment. The MMS supervises mineral leasing, exploration, development, and production on the OCS. It is responsible for oil rig safety, oil rig pollution control regulations, determination of the environmental impact of resource development, and estimation and evaluation of oil and gas resources. The MMS also has the arthority to lease the OCS for ocean mining of hard minerals. At present, revenues from the Alaska OCS are primarily derived from competitive leasing activities; no development or production is occurring on the Alaska OCS at this time. The responsibility of the MMS for onshore Alaskan minerals is limited to the collection of royalties, bor'uses, and rents from Federal and certain Native lands.

The MMS holds synthesis meetings and information transfer meetings, scoping meetings, and public hearings on Environmental Impact Statements. To determine public concerns for consideration and inclusion in EIS's, scoping meetings related to specific planning or subject areas are held in the local villages. The public is invited to attend these meetings and can contact the MMS Regional Office for specific subjects, dates, and times.

In Alaska, the MMS is active in assessir o the oil and gas potential of offshore basins through the analysis of geophysical and geologic data. This work is integrated into the National Resource Assessment and is a basis for evaluations of the potential monetary worth of individual OCS lease blocks, for appraisals of the resource potential of entire basins, and for the formulation of geologic models of basin development. The MMS conducts specialized studies of geologic and geophysical data obtained from DST wells and exploratory wells drilled on OCS lands. The results of these studies are published through the MMS OCS Report series or in appropriate scientific journals. The MMS also sponsors resource-oriented geologic studies through the Program for Studies Related to Continental Margins, which funds research by State agencies and affiliated academic institutions.

\section{BUREAU OF LAND MANAGEMENT}

The BLM manages Federal onshore mineral resources. The BLM also works cooperatively with the NPS, FWS, and USFS to provide technical evaluation of the mineralrelated issues on lands under these agencies' jurisd ‘tion.

Management decisions concerning all minerals on the 372,312 square kilometers of land currently managed by the BLM in Alaska (fig. 1) are made through the Resource Management Planning process. The BLM first identifies the mineral potential of each planning unit. The effects of minerals exploration, development and production, and land abandonment and rehabilitation are then analyzed in regard to the needs and sensitivities of the other resources present. Mitigation measures are developed and evaluated to reduce or avoid adverse impacts of the anticipated mine al activities. Field monitoring of all phases of mineral antivity attempts to ensure that no unnecessary or undue de?radation occurs. The BLM also provides resource management for retained Federal mineral estates on an additional 404,673 square kilometers. 


\section{NATIONAL PARK SERVICE}

In 1916, Congress established the National Park Service and stated in its Organic Act that the fundamental purpose of the Nation's parks, monuments, and other reservations was "to conserve the scenery and natural and historic objects and wildlife therein and to provide for the enjoyment of the same in such manner and by such means as will leave them unimpaired for the enjoyment of future generations" (39 Stat. 535, NPS Organic Act). NPS management policies are based on the concept of ecosystem stewardship, conservation, and preservation while providing for appropriate public enjoyment of the natural and cultural resources within individual units of the National Park System.

Congress enacted the Mining in the Parks Act in 1976, declaring that the continued application of the Mining Law of 1872 on park lands conflicts with the purposes for which parks were established. The Act closed all park lands to further exploration and mining activities and stipulated that mining operations with prior existing rights "...be conducted so as to prevent or minimize damage to the environment and other resource values" (90 Stat. 1342).

The ANILCA in 1980 dramatically increased NPS involvement with minerals management issues. The Act expanded the National Park System in Alaska to over 206,391 square kilometers and incorporated over 4,000 unpatented and 1,800 patented mining claims and other private inholdings within park unit boundaries. ANILCA provided specific directions for minerals management for some units and also directed the NPS to regulate mineralresource assessments under the AMRAP.

The NPS manages mining-related activities on patented and unpatented mining claims through regulations found in Title 36 CFR, Part 9, Subpart A; non-Federal oil and gas development through regulations found in Subpart $\mathrm{B}$; and AMRAP program activities through regulations found in Subpart D. Since 1990, NPS's mineral management activities on Federal mining claims in Alaska have been directed by three U.S. District Court and 9th Circuit Court approved Environmental Impact Statements on the cumulative impacts of mining in Denali NP\&P, WrangellSt. Elias NP\&P, and Yukon-Charley Rivers National Preserve. The Records of Decisions in all three EIS's direct the NPS to acquire all mining properties within park boundaries, manage all future mining within the stringent guidelines of NPS regulations, and reclaim all lands impacted by mining. Since that decision, the NPS has developed and initiated a claim acquisition program, refined and expanded its claim management capabilities, and developed and implemented a mineral lands restoration program.

\section{U.S. FISH AND WILDLIFE SERVICE}

The FWS provides Federal leadership to conserve, protect, and enhance fish and wildlife and their habitats for the continuing benefit of people. In Alaska, the FWS seeks to accomplish this mission through programs that implement provisions of the Endangered Species Act, Marine Mammal Protection Act, Fish and Wildlife Coordination Act, National Wildlife Refuge System Administration Act, ANILCA, Rivers and Harbors Act, Clean Water Act, various migratory-bird laws and treaties, and other statutes.

Under ANILCA, 16 refuges in Alaska (fig. 3) were created or enlarged to conserve fish and wildlife populations and their habitats, as well as other values. Except for valid rights existing at the time of establishment, these refuges are closed to entry and location under mining laws. The refuges are open to entry under leasing laws but are closed to the mining of coal by the Federal Coal Leasing Amendments Act of 1975 and are closed tc geothermal resource leasing by the Geothermal Steam Act of 1970 . Although many traditional activities have been deemed appropriate for these refuges, other uses, including oil and gas leasing, will be permitted only when such activities are compatible with the purposes for which a specific refuge was established.

\section{DEPARTMENT OF AGRICULTURE}

\section{U.S. FOREST SERVICE}

The mission of the USFS is to provide a continuing flow of natural-resource goods, including mineral and energy resources, to help meet national needs and to contribute to meeting such needs worldwide. It is the responsibility of the USFS to encourage and support environmentally sound mineral enterprises on Federal lands under its administration. In managing the use of these resources, the USFS chjective is to minimize unnecessary adverse environmental impacts to surface and cultural features and values that might result from lawful exploration and development operations. This objective is accomplished through the application cf reasonable conditions that do not interfere with well-plarned mineral operations. The USFS also provides research information and technology to help with post-mining reclamation. In implementing this policy, the USFS Chief directed that:

1. A key objective of the minerals program is to encourage and facilitate the orderly exploration, development, and production of mineral resources.

2. Minerals, like range, recreation, timber, water, wildlife, and wilderness, are one of the multiple resources that the USFS manages.

3. USFS managers must develop a good understanding of the minerals industry, its practices, and the minerals laws and regulations.

4. Managers must develop a strong working relationship with the minerals industry.

5. Visibility and interaction with the minerals industry must be increased by attendance and participation of 
line officers and appropriate staff at industry and professional association activities and meetings.

6. Directories, organization charts, and receptionists direct the public and mineral industry operatives to personnel who have minerals-administration responsibilities.

\section{DEPARTMENT OF ENERGY}

The DOE's mission is to reduce the Nation's vulnerability to disruptions of energy supplies and to mitigate any adverse impacts on the Nation should a shortage occur. With regard to Alaska, the energy sources currently being addressed by the DOE are fossil fuels (petroleum and coal) and geothermal.

The strategy for responding to petroleum-supply interruptions is to rely on the free market, supplemented as necessary and appropriate with other measures, such as the Strategic Petroleum Reserve. The DOE's Fossil Energy Research and Development Programs are aimed at careful consideration of the alternatives available and the relative chances for success in fostering an adequate supply' of energy at a reasonable cost through long-term, high-risk research and development. Alternatives for increasing domestic petroleum supplies include (1) DOE's Natural Gas Technology Program, which emphasizes the development of advanced technologies for the extraction of natural gas from resources that are classified as nonconventional because of unique geologic settings and production mechanisms that are not now well understood, and (2) DOE programs for d?veloping tertiary oil recovery, tar sands, and heavy-oil deposits.

The purpose of the DOE's Geothermal En rrgy Program is to develop the technology needed by industry for the use of geothermal resources. DOE research is aimed toward improving methods used to locate, extract, and convert geothermal heat to usable forms of energy. Through DOE funding in Alaska, Federal and State agen ries have researched and published several studies of sperific geothermal systems.

A further purpose of DOE programs is to generate data essential to the private sector's decision-making process to facilitate the development of commercial projects. 





\section{SELECTED SERIES OF U.S. GEOLOGICAL SURVEY PUBLICATIONS}

\section{Periodicals}

Earthquakes \& Volcanoes (issued bimonthly).

Preliminary Determination of Epicenters (issued monthly).

\section{Technical Books and Reports}

Professional Papers are mainly comprehensive scientific reports of wide and lasting interest and importance to professional scientists and engineers. Included are reports on the results of resource studies and of topographic, hydrologic, and geologic investigations. They also include collections of related papers addressing different aspects of a single scientific topic.

Bulletins contain significant data and interpretations that are of lasting scientific interest but are generally more limited in scope or geographic coverage than Professional Papers. They include the results of resource studies and of geologic and topographic investigations, as well as collections of short papers related to a specific topic.

Water-Supply Papers are comprehensive reports that present significant interpretive results of hydrologic investigations of wide interest to professional geologists, hydrologists, and engineers. The series covers investigations in all phases of hydrology, including hydrogeology, availability of water, quality of water, and use of water.

Circulars present administrative information or important scientific information of wide popular interest in a format designed for distribution at no cost to the public. Information is usually of shortterm interest.

Water-Resource Investigations Reports are papers of an interpretive nature made available to the public outside the formal USGS publications series. Copies are reproduced on request unlike formal USGS publications, and they are also available for public inspection at depositories indicated in USGS catalogs.

Open-File Reports include unpublished manuscript reports, maps, and other material that are made available for public consultation at depositories. They are a nonpermanent form of publication that may be cited in other publications as sources of information.

\section{Maps}

Geologic Quadrangle Maps are multicolor geologic maps on topographic bases in $71 / 2$ - or 15-minute quadrangle formats (scales mainly $1: 24,000$ or $1: 62,500$ ) showing bedrock, surficial, or engineering geology. Maps generally include brief texts; some maps include structure and columnar sections only.

Geophysical Investigations Maps are on topographic or planimetric bases at various scales; they show results of surveys using geophysical techniques, such as gravity, magnetic, seismic, or radioactivity, which reflect subsurface structures that are of economic or geologic significance. Many maps include correlations with the geology.

Miscellaneous Investigations Series Maps are on planimetric or topographic bases of regular and irregular areas at various scales; they present a wide variety of format and subject matter. The series also includes 7 1/2-minute quadrangle photogeologic maps on planimetric bases that show geology as interpreted from aerial photographs. Series also includes maps of Mars and the Moon.
Coal Investigations Maps are geologic maps on topographic or planimetric bases at various scales showing bedrock or surficial geology, stratigraphy, and structural relations in certain coal-resource areas.

Oil and Gas Investigations Charts show stratigraphic information for certain oil and gas fields and other areas having petroleum potential.

Miscellaneous Field Studies Maps are multicolor or black-andwhite maps on topographic or planimetric bases on quadrangle or irregular areas at various scales. Pre-1971 maps show bedrock geology in relation to specific mining or mineral-deposit problems; post-1971 maps are primarily black-and-white maps on various subjects, such as environmental studies or wilderness mineral investigations.

Hydrologic Investigations Atlases are multicolor or black-andwhite maps on topographic or planimetric bases presenting a wide range of geohydrologic data of both regular and irregular areas; principal scale is 1:24,000, and regional studies are at 1:250,000 scale or smaller.

\section{Catalogs}

Permanent catalogs, as well as some others, giving comprehensive listings of U.S. Geological Survey publications are available under the conditions indicated below from the U.S. Geological Survey, Books and Open-File Reports Sales, Federal Center, Box 25286, Denver, CO 80225. (See latest Price and Availability List.)

"Publications of the Geological Survey, 1879-1961" may be purchased by mail and over the counter in paperback book form and as a set of microfiche.

"Publications of the Geological Survey, 1962-1970" may be purchased by mail and over the counter in paperback book form and as a set of microfiche.

"Publications of the Geological Survey, 1971-1981" may be purchased by mail and over the counter in paperback book form (two volumes, publications listing and index) and as a set of microfiche.

Supplements for 1982, 1983, 1984, 1985, 1986, and for subsequent years since the last permanent catalog may be purchased by mail and over the counter in paperback book form.

State catalogs, "List of U.S. Geological Survey Geologic and Water-Supply Reports and Maps For (State)," may be purchased by mail and over the counter in paperback booklet form only.

"Price and Availability List of U.S. Geological Survey Publications," issued annually, is available free of charge in paperback booklet form only.

Selected copies of a monthly catalog "New Publications of the U.S. Geological Survey" are available free of charge by mail or may be obtained over the counter in paperback booklet form only. Those wishing a free subscription to the monthly catalog "New Publications of the U.S. Geological Survey" should write to the U.S. Geological Survey, 582 National Center, Reston, VA 22092.

Note.--Prices of Government publications listed in older catalogs, announcements, and publications may be incorrect. Therefore, the prices charged may differ from the prices in catalogs, announcements, and publications. 
